\title{
IN PURSUIT OF THE GRAND IDEA
}

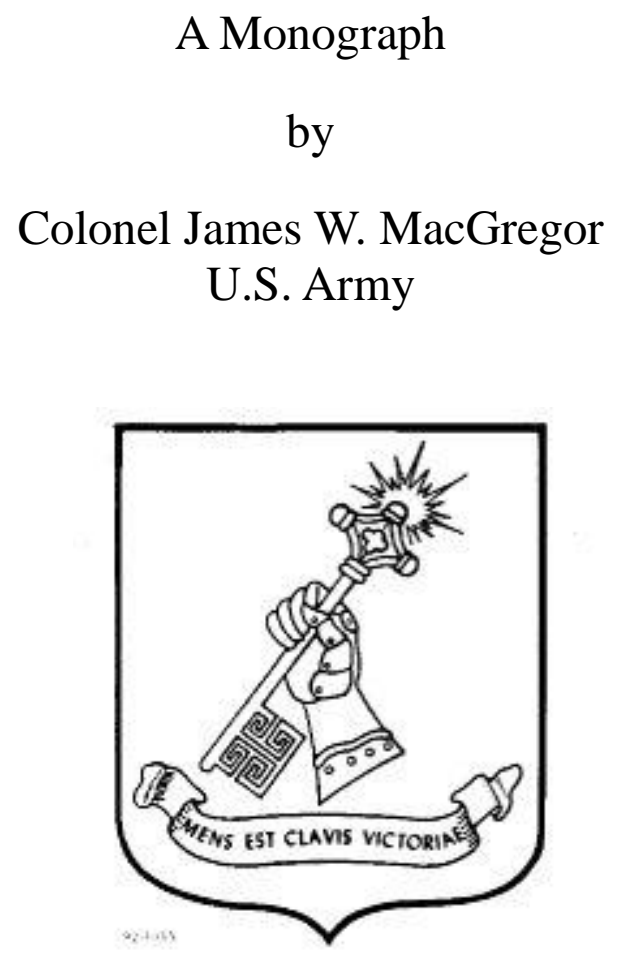

School of Advanced Military Studies

United States Army Command and General Staff College

Fort Leavenworth, Kansas

AY 2013-2014 
Public reporting burden for this collection of information is estimated to average 1 hour per response, including the time for reviewing instructions, searching existing data sources, gathering and

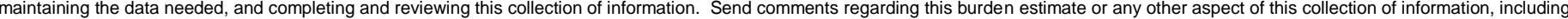

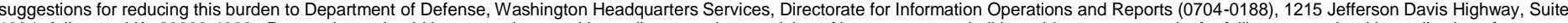
1204, Arlington, VA 22202-4302. Respondents should be aware that notwithstanding any other provision of law, no person shall be subject to any penalty for failing to comply with a collection of information if it does not display a currently valid OMB control number. PLEASE DO NOT RETURN YOUR FORM TO THE ABOVE ADDRESS.

\begin{tabular}{l|l} 
1. REPORT DATE $(D D-M M-Y Y Y Y)$ & 2. REPORT TYPE
\end{tabular}

\begin{tabular}{l|l}
$22-05-2014$ & Master's Thesis
\end{tabular}

\section{TITLE AND SUBTITLE}

IN PURSUIT OF THE GRAND IDEA

\section{DATES COVERED (From - To)}

June 2013 - May 2014

5a. CONTRACT NUMBER

5b. GRANT NUMBER

5c. PROGRAM ELEMENT NUMBER

\section{AUTHOR(S)}

5d. PROJECT NUMBER

MacGregor, James W.

5e. TASK NUMBER

5f. WORK UNIT NUMBER

\section{PERFORMING ORGANIZATION NAME(S) AND ADDRESS(ES)}

School of Advanced Military Studies

250 Gibbon Avenue

Fort Leavenworth, Kansas 66027-2134

8. PERFORMING ORGANIZATION REPORT

\section{SPONSORING / MONITORING AGENCY NAME(S) AND ADDRESS(ES) \\ Command and General Staff College \\ 731 McClellan Avenue \\ Fort Leavenworth, Kansas 66027-2134}

10. SPONSOR/MONITOR'S

ACRONYM(S)

11. SPONSOR/MONITOR'S REPORT NUMBER(S)

\section{DISTRIBUTION / AVAILABILITY STATEMENT}

Approved for public release; distribution is unlimited.

\section{SUPPLEMENTARY NOTES}

\section{ABSTRACT}

The Truman Doctrine and containment policy formed the foundation of most American national security activities and decisions throughout the Cold War. Since the end of the Cold War, many national security experts, analysts, and students believe the United states has failed to find the same success identifying its interests and articulating the ideas, policies, and strategies necessary to achieve or defend them. They suggest the United States is without direction and unable to exploit its superiority across all domains of power.

Through a comparison of the Harry S. Truman (1945-1953), George H.W. Bush (1989-1993), and William J. Clinton (1993-2001) presidencies, this paper explores national security policymaking with a focus on the diversity of ideas within each period and the actors, in and out of government, who introduced and advocated those ideas. The author identifies challenges that inhibit pursuit of grand strategy and policymaking in the United States and reviews how Truman benefited from conditions not present in the Bush and clinton eras. The author concludes with recommended reforms to both organizations and procedures that, combined with stronger leadership and greater nonpartisanship, might improve the United States' ability to find a new grand idea.

\section{SUBJECT TERMS}

Foreign Affairs, National Security, Strategy, Policymaking, Strategic Leadership, Harry S. Truman, George H.W. Bush, William J. Clinton, George F. Kennan, Containment, Presidential Doctrines

\begin{tabular}{|c|c|c|c|c|c|}
\hline 16. SECURITY CLAS & ION OF: & & $\begin{array}{l}\text { 17. LIMITATION } \\
\text { OF ABSTRACT }\end{array}$ & $\begin{array}{l}18 . \\
\text { NUMBER }\end{array}$ & $\begin{array}{l}\text { 19a. NAME OF RESPONSIBLE } \\
\text { PERSON }\end{array}$ \\
\hline $\begin{array}{l}\text { a. REPORT } \\
\text { Unclassified }\end{array}$ & $\begin{array}{l}\text { b. ABSTRACT } \\
\text { Unclassified }\end{array}$ & $\begin{array}{l}\text { c. THIS PAGE } \\
\text { Unclassified }\end{array}$ & UU & 53 & $\begin{array}{l}\text { 19b. TELEPHONE NUMBER } \\
\text { (include area code) }\end{array}$ \\
\hline
\end{tabular}




\section{MONOGRAPH APPROVAL}

Name of Candidate: Colonel James W. MacGregor

Monograph Title: $\quad$ In Pursuit of the Grand Idea

Approved by:

Robert T. Davis, II, Ph.D.

, Monograph Director

Deputy Director Academics, School of Advanced

G. Scott Gorman, Ph.D. Military Studies

, Director, School of Advanced Military Studies

Henry A. Arnold III, COL, IN

Accepted this $22^{\text {nd }}$ day of May 2014 by:

Robert F. Baumann, Ph.D.

, Director, Graduate Degree Programs

The opinions and conclusions expressed herein are those of the student author, and do not necessarily represent the views of the U.S. Army Command and General Staff College or any other government agency. (References to this study should include the foregoing statement.) 


\begin{abstract}
IN PURSUIT OF THE GRAND IDEA, by Colonel James W. MacGregor, U.S. Army, 101 pages.

The Truman Doctrine and containment policy formed the foundation of most American national security activities and decisions throughout the Cold War. Since the end of the Cold War, many national security experts, analysts, and students believe the United States has failed to find the same success identifying its interests and articulating the ideas, policies, and strategies necessary to achieve or defend them. They suggest the United States is without direction and unable to exploit its superiority across all domains of power.
\end{abstract}

Through a comparison of the Harry S. Truman (1945-1953), George H.W. Bush (1989-1993), and William J. Clinton (1993-2001) presidencies, this paper explores national security policymaking with a focus on the diversity of ideas within each period and the actors, in and out of government, who introduced and advocated those ideas. The author identifies challenges that inhibit pursuit of grand strategy and policymaking in the United States and reviews how Truman benefited from conditions not present in the Bush and Clinton eras. The author concludes with recommended reforms to both organizations and procedures that, combined with stronger leadership and greater nonpartisanship, might improve the United States' ability to find a new grand idea. 


\section{ACKNOWLEDGEMENTS}

I would like to thank my family—Debbie and kids—-without whom no things would be possible or worth doing. Thank you for your patience and for the small space of the living room that became my office. I am also indebted to Dr. John Lewis Gaddis and Reverend Wilson D. Miscamble who graciously took time out of their busy schedules to provide some thoughts and direction early in my project. 


\section{TABLE OF CONTENTS}

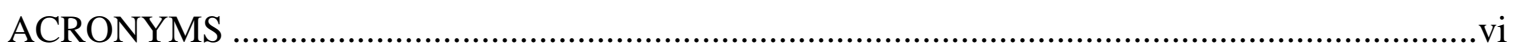

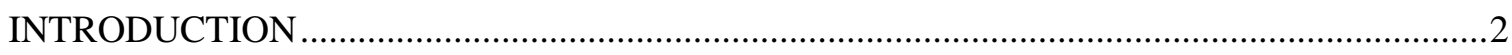

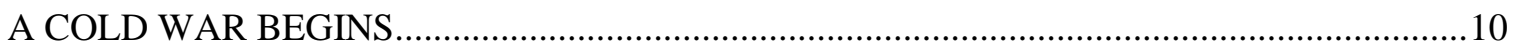

National Security during the Harry S. Truman Administration ............................................. 13

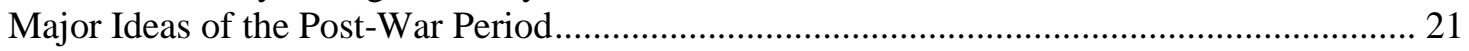

The Congress and National Security Reorganization ......................................................... 33

POST COLD WAR

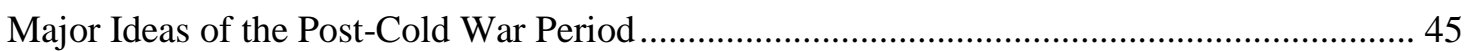

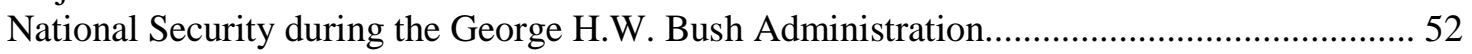

National Security during the William (Bill) J. Clinton Administration .....................................56

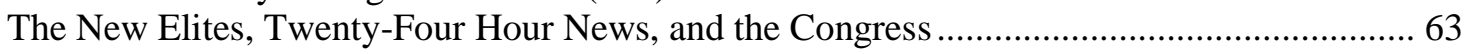

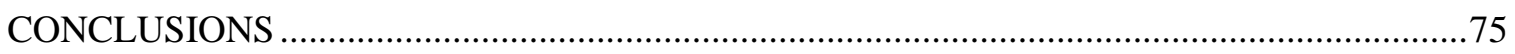

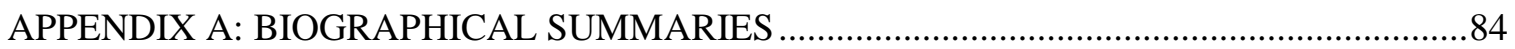

APPENDIX B: NATIONAL SECURITY DOCTRINES OF U.S. PRESIDENTS ......................87

APPENDIX C: AMERICAN NATIONAL SECURITY POLICY TRADITIONS .....................90

APPENDIX D: UNCITED REFERENCES FOR ADDITIONAL RESEARCH .......................91

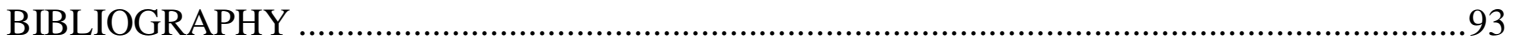




\section{ACRONYMS}

CFR Council on Foreign Relations, publishes Foreign Affairs

CJCS Chairman, Joint Chiefs of Staff

CIA Central Intelligence Agency

CSIS Center for Strategic \& International Studies, publishes The Washington Quarterly

DOD Department of Defense

DOS Department of Statement

ERP Economic Recovery Plan, i.e., the Marshall Plan (1948-1952)

HASC U.S. House of Representatives Armed Services Committee

HFRC U.S. House of Representatives Foreign Relations Committee

JCS Joint Chiefs of Staff

NATO North Atlantic Treaty Organization, formed by the North Atlantic Treaty

NSA National Security Advisor

NSC National Security Council

NSS National Security Strategy

OMB Office of Management and Budget

PRC Peoples' Republic of China; China

PPS Policy Planning Staff, Department of State

SASC U.S. Senate Armed Services Committee

SFRC U.S. Senate Foreign Relations Committee

U.K. United Kingdom

U.N. United Nations

U.S. United States

U.S.S.R. Union of Soviet Socialist Republics; the Soviet Union (1917-1991)

WWI World War I (1914-1918; United States participated 1917-1918)

WWII World War II (1939-1945; United States participated 1941-1945) 


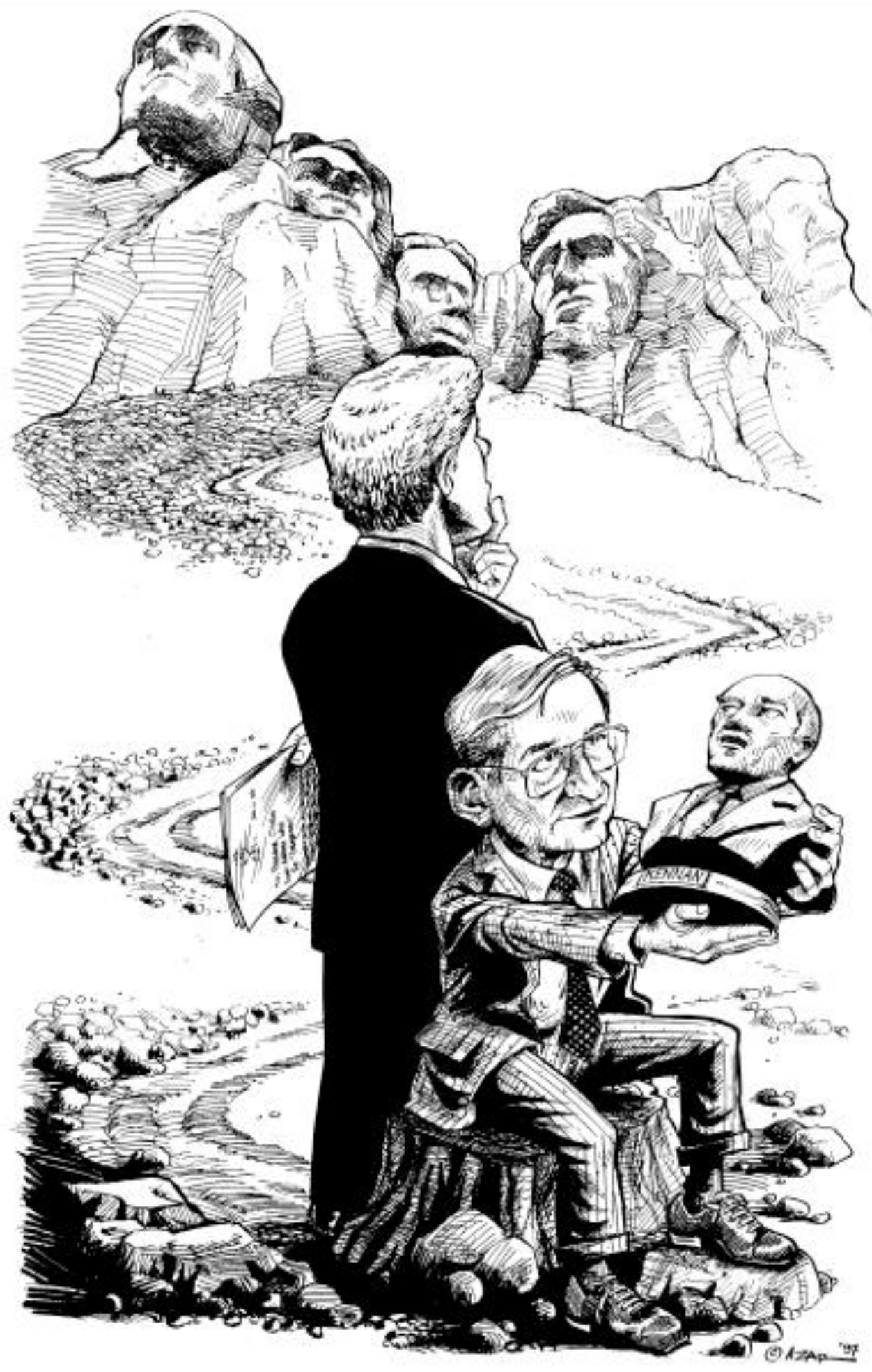

Source: Illustration by Joseph Azar. Foreign Policy, Spring 1997, page 110. ProQuest accessed December 22, 2013. [Used with permission of illustrator] 


\section{INTRODUCTION}

The cartoon on the preceding page, published in 1997, captures President William (Bill) Clinton contemplating his legacy as his National Security Advisor, Anthony Lake, yearningly looks to a bust of George Kennan for wisdom and direction. The cartoon and accompanying article showed that Kennan, a former Foreign Service officer thirty-five years into retirement, still possessed a reputation of near mythical proportions amongst those responsible for national security policy in the United States (U.S.). According to this reputation, Kennan was the intellectual force behind the national security policy of containment adopted by the Truman Administration and continued by his successors throughout the Cold War. Kennan found what others after him sought — the grand idea that captured the imagination of a nation, guided its national security activities, and enshrined its creator in the annals of history. In contrast, twentyfive years after the Cold War ended, the search—for the next man and the new idea—continues. ${ }^{1}$

At least one national security expert believes the search continues because the United States suffers from a "deficit of strategic thinking." According to this argument, rather than adapting to an environment in which it lacks a peer competitor on which it can focus its energies, the United States continues to struggle with a host of vague challenges and fleeting opportunities. Furthermore, as concerns over domestic economic security and the federal debt have grown, policymakers conditioned to a relatively unconstrained fiscal environment now find their options

\footnotetext{
${ }^{1}$ On February 5, 2014, an article about the Obama Administration's pursuit of a path to peace in the Middle East identified Stephen Walt, a Harvard University Professor, as the new Kennan. See Lee Smith, “As Kennan Inspired Truman's Foreign Policy, Now Stephen Walt Inspires Obama's," Tablet (February 5, 2014), http://www.tabletmag.com/jewish-news-and-politics/161815/stephen-walt-the-newkennan (accessed February 6, 2014). The article included a "picture" of President Barak Obama sitting with Kennan. Ironically, in 1994, Kennan warned Secretary of State Warren Christopher to avoid "searching for a single grand strategy concept." Warren Christopher, In the Stream of History: Shaping Foreign Policy for a New Era (Stanford, CA: Stanford University Press, 1998), 242. The myth is flawed. It is unfair to other members of the Truman Administration-Truman, Secretary of State George Marshall, Undersecretary of State Dean -Acheson, and countless others - by crediting Kennan alone for containment and Kennan would reject credit assigned him for the Truman Doctrine. See next chapter.
} 
limited in ways in which they are not familiar or comfortable. These men and women, formerly able to rely on overwhelming advantages in military and economic power, must now be more creative, discerning, and deliberate to achieve more with less. Unfortunately, these traits clash with a senior leader preference to manage by crisis across the domestic and foreign environments. Situational problem solving at best, delay and indecision at worst, seem more prevalent than reflective thinking, considered debate, and perseverance. ${ }^{2}$

Others, including Alexis de Tocqueville, the nineteenth century French observer of American democracy, suggest the United States and other democracies are permanently disadvantaged in national security affairs because the constant pressure of domestic politics inhibits effective statecraft. Anthony Lake seems to share this perspective. Several years before the cartoon appeared, Lake co-authored a book that claimed, "American foreign policy is in a perpetual state of crisis" for which the polarization of ideas, theatrics of domestic politics, and drastic swings in public sentiment—hallmarks of a vibrant democracy — are partly responsible. The very nature of bureaucratic and electoral politics, especially the influence of public opinion, interest groups, and the media who inform them, molds — not always positively — every aspect of policymaking from the selection of staff, the deliberation and implementation of new concepts, and the organization of resources. As a result, policymakers typically fail in their pursuit of a unifying grand strategy and as a result, default to no effective strategy at all. ${ }^{3}$

\footnotetext{
${ }^{2}$ In a meeting attended by the Advanced Strategic Leadership Studies Program (ASLSP) Senior Students in July 2013, a prominent expert not affiliated with the government used the phrase "deficit of strategic thinking" to describe the state of American foreign relation and national security policymaking. Comments were not for attribution. On the preference for crisis management, "Crisis Management: A Primer" (1998) by Carnes Lord and "The Lie That Screwed Up 50 Years of U.S. Foreign Policy" (2012) by Leslie Gelb serve as useful references. An alternative to doing more with less is doing the same or less with less, but that never seems to be the norm.

${ }^{3}$ George F. Kennan and John Lukacs, George F. Kennan and the Origins of Containment, 19441946: the Kennan-Lukacs Correspondence (Columbia, MO: University of Missouri, 1997), 6; I. M. Destler, Leslie H. Gelb, and Anthony Lake, Our Own Worst Enemy: the Unmaking of American Foreign Policy
} 
Given these dynamics, several questions emerge. How has the United States formulated its national security strategy? If the Kennan legend is accurate, how did the United States achieve policymaking success in the aftermath of World War II? What obstacles and advantages exist in its policymaking process? Who are the key players and in what forums do they exchange and contest ideas? Finally, can and should the United States seek a single grand, strategic idea?

Before continuing, a comment on word choice is important. The terms grand strategy, national security strategy, and foreign policy mean different things to different people. To this author, grand strategy is "the art and science of synchronizing and integrating the elements of national power to further the aims of the state in peace and war." Grand strategy articulates a view of the domestic and international environments, describes how they should look to serve the state's interests, and then establishes a path to reconcile differences between present and desired conditions. It rarely resolves the gap between present and desired circumstances immediately; rather, grand strategy purchases time for deliberation, the steady advancement of interests, and gradual change. Historical experience, religions and cultures, traditions and doctrines, and interests, both vital and national, inform grand strategy, but a grasp of context, a recognition of the feasible and infeasible, an acknowledgment of allied, neutral, and enemy interests, and an assessment of risks delineate limits and objectives. Grand strategy is holistic, with diplomatic or foreign, economic, military, and communication policies nested and subordinate. ${ }^{4}$

(New York: Simon and Schuster, 1984), 261, 266-271; Christopher, In the Stream of History: Shaping Foreign Policy for a New Era, 74n; Stephen D. Krasner, "An Orienting Principle for Foreign Policy," Policy Review (October-November 2010): 4.

${ }^{4}$ Krasner, 4 . The author's definition of grand strategy first appeared in a writing assignment for ASLSP. It relies heavily on classroom discussion, a review of joint military doctrine, and two books, Everett C. Dolman, Pure Strategy: Power and Principle in the Space and Information Age (New York: Frank Cass, 2005) and Lamont Colucci, The National Security Doctrines of the American Presidency (Santa Barbara, CA: Praeger Security International, 2012). The Goldwater-Nichols Act of 1986 establishes the requirement for the President to provide an annual report on the National Security Strategy. Ideally, policies flow from grand or national security strategies and national security strategies flow from doctrines 
When the President fulfills his statutorial obligation to publish an annual report on the National Security Strategy (NSS), in essence, he has the opportunity to make a statement on grand strategy. For this reason, the author adopted the term "national security" in lieu of "grand" strategy for use in this monograph. The "grand idea" refers to a sustainable, guiding concept or related concepts that ideally transcend a single four- or eight-year presidential cycle, underpin national security strategy, and provide focus and direction for the nation. ${ }^{5}$

To study the pursuit of grand ideas, this monograph presents and compares two case studies inclusive of three Administrations_-Truman (1945-1953), George H.W. Bush (19891993), and Clinton (1993-2001). These Administrations overlap two of the three most dramatic periods in modern U.S. history - the transition from World War II (WWII) into the Cold War as a superpower and the end of the Cold War marked by the collapse of the Soviet Union. The third period - that occurring after the terrorist attacks of September 11,2001-is recent enough in time to make it a contemporary, not quite historical, event. This complicates its utility as a case study now, but in time, offers itself an area for future research. Similar in some respects, the case studies highlight stark differences in the willingness and ability of the key players to isolate and promote a dominant national security strategy. ${ }^{6}$

or organizing principles. In many cases, the U.S., as an established great power, seeks nothing more than maintenance of or managed change within the status quo. An emergent or frustrated power is more likely to act aggressively and seek change in the status quo. As President George H.W. Bush showed in 1989-1991, this abundance of caution by established great powers can be a positive or negative trait.

${ }^{5}$ For a list of commonly presidential doctrines, see Appendix B: National Security Doctrines. Lord similarly adopts "national security" to encapsulate the diplomatic and military sides of the same coin. He acknowledges, but rejects, the argument that the term is ideologically laden with greater emphasis on military over diplomatic solutions. See Presidency and the Management of National Security, 35.

${ }^{6}$ In The Superpowers: The United States, Britain and the Soviet Union-Their Responsibility for Peace (1944), William T.R. Fox, an American foreign policy expert and the first Director of Columbia University's Institute of War \& Peace Studies, described a superpower as a state capable of challenging others on a global scale. As the title suggests, he believed there were three. In the postwar years, as the U.S. and Soviets developed substantial nuclear arsenals and the British lost their empire (i.e., India, colonies in Asia and Africa) and their prestige (i.e., Suez Crisis in 1956), the number dwindled to the two primary 
Whatever their merits or faults, historians and political scientists almost universally acknowledge Truman and his advisors, including Kennan, brought into being ideas that outlasted their time in government. Those who followed may have deviated from them from time-to-time but generally, the Truman-era approach provided the building blocks on which seven successive Administrations based national security actions. Because the Bush and Clinton Administrations, like Truman, presided over a transformative period, but unlike Truman, failed to establish a recognized and sustainable doctrine or strategic concept, they serve as a useful contrast.

The American-Soviet/Russian relationship dominates this paper as it does many studies of these three presidencies. This does not mean there were no other issues of import to the United States, but merely recognizes that economic, military, and political competition with the Soviets influenced them all. American attempts to expand foreign markets, deconstruct colonial empires, and empower the United Nations (U.N.) all occurred in the shadows of a titanic struggle between two hostile ideologies and economic models. The public and historians judge presidential legacies from Truman through Ronald Reagan (1981-1989) on their perceptions of ground gained or lost relative to the Soviets. The belief that the "will and ability of the leaders of the [Soviet Union] to pursue policies which threaten the security of the United States constitute the greatest single danger to the United States within the foreseeable future" was indeed a powerful motivator. In a

competitors of the Cold War. Of note, Dwight D. Eisenhower established the Institute of War \& Peace when he was President of Columbia University (1948-1953, with breaks in service as Chairman of the Joint Chiefs and Supreme Allied Commander-Europe). In 2005, newly appointed Secretary of State Condoleezza Rice wrote, "Soon after arriving at the State Department I hung a portrait of Dean Acheson in my office. Like Acheson and his contemporaries, we live in an extraordinary time - one in which the terrain of international politics is shifting beneath our feet and the pace of historical change outstrips even the most vivid imagination." It suggests continued fascination with the Truman Administration and frustration the United States had, fourteen years after the Cold War ended, was still searching for a new idea to replace the Truman Doctrine and containment as America's grand idea. The G.W. Bush Administration will likely look more like the previous two than Truman's were one to study it in the context this paper follows. 
similar sense, the disintegration of the Soviet Union and its sphere directly contributed to the trials and opportunities Bush and Clinton encountered. ${ }^{7}$

Some thoughts on the structure of this paper may be useful for the reader. First, the case studies are similar in content. Each contains a short introduction, reviews actions by the Administration(s) from the perspective of the President, introduces some of the major ideas from the period, and ends with an assessment of others - the Congress, the bureaucracy, think tanks, and media amongst them—who influenced the policymaking process. This paper necessarily simplifies Congress, with includes 535 independently minded members, to just a few members and broad trends. Similarly, to conserve space, a sample of think tanks and media must suffice.

Second, where possible, references from the period were preferable to those written later because they reveal thinking at the time, not reflection in hindsight. Unfortunately, limitations in time and lack of access to diaries, personal papers, and government documents did not broadly support this preference. As the bibliography and other resources list show, there is no shortage of material on the Truman Administration, the start of the Cold War, and American policies of that period. Accessible material on the Bush and Clinton Administrations was adequate, but not nearly as voluminous or supportive of this approach. The main text contains only essential biographical data; biographical sketches of key individuals are included in Appendix A.

Third, it was not the goal of this monograph to assess thoughts, ideas, or policies these men and women generated. It quickly became clear, in a way the author did not expect, that

\footnotetext{
${ }^{7}$ United States Department of State, Foreign Relations of the United States, 1948: General, The United Nations. Vol. I, Part 2. (Washington, DC: U.S. Government Printing Office, 1948), 663. This quote is from National Security Council (NSC) 20/4, titled, "U.S. Objectives with Respect to the USSR to Counter Soviet Threats to U.S. Security." See closing paragraphs of the "A Cold War Begins" section of this paper. Cold War revisionists dispute this assessment of the Soviets and suggest the United States was as much or more to blame for the onset of the Cold War. There is perhaps some truth to this argument, but that debate is outside the scope of this paper. This paper focuses on how the U.S. government dealt with threats and opportunities, as it perceived them. See Other Reference Materials and Note 8.
} 
competent historians and political scientists disagree on truths commonly held by the American people about the start and nature of the Cold War. The argument between traditionalists and revisionists, while fascinating and worthy of study, is not the focus of this project. Similarly, there was no shortage of perspectives at the end of the Cold War. The author sought to understand how roles and relationships aid or hinder pursuit of "the" idea, not the wisdom of the idea itself. ${ }^{8}$

Finally, the underlying assumption behind this monograph is that a single grand idea, articulated in national security documents and statements, is desirable. It seems intuitive that such an idea would focus senior Foreign Service and military officers and improve their effectiveness. Nebulousness may appeal to politicians attempting to be all things to all people, but the diplomat and soldier tend to prefer simplicity, boundaries, and direction. Similarly, clarity of purpose and direction reassures allies and informs enemies. For better or worse, Truman, in his March 1947 address to Congress, made explicit American intentions and in doing so, he galvanized a people, their government, their friends, and their enemies in a manner ambiguity could not have achieved.

At the end of this project, the author arrived at several conclusions that should become clear in the words that follow. First, the circumstances that enabled George Kennan and others to achieve what they did within the Truman Administration were unique. Victory in not one, but two wars, inspired action by men who possessed a palpable fear of communism, smaller doses of the naïve innocence held by their predecessors, and less cynicism than that which plagued their successors. Second, there are significant structural obstacles to effective policymaking in the United States. No one ever said, however, that democracy would be easy or efficient. Domestic traditions, attitudes, and election cycles do indeed influence—-for better and worse-American

${ }^{8}$ Traditional or post-revisionist interpretations of the Cold War argue the United States was right to assume the Soviet Union was a threat. John Lewis Gaddis is the most prominent contemporary author who takes this position. Revisionists argue the United States was equally or more responsible for the onset of the Cold War. They suggest the Truman Administration was either misguided or disingenuous in its intentions. William Appleman Williams, Walter LeFeber, and Melvyn Leffler make these arguments. 
statecraft. Finally, given the first two conclusions, the pursuit of a single grand idea may be difficult, but in some form, it is necessary to provide focus and prioritize resources. The alternative is an exhausted nation, unable to protect its people and guarantee its prosperity, as it struggles to find balance between what it must do and that which it wishes to do. 
The United States stands at this time at the pinnacle of world power. It is a solemn moment for the American Democracy. For with primacy in power is also joined an aweinspiring accountability to the future ... To reject it or ignore it or fritter it away will bring upon us all the long reproaches of the after-time ...

- Winston Churchill, The Sinews of Peace ${ }^{9}$

\section{A COLD WAR BEGINS}

When Winston Churchill, former Prime Minister of the United Kingdom spoke in Fulton, Missouri in early 1946, he issued a call to action to Americans. Europe and Asia lay burdened with an unimaginable "sum of human pain" and yet, he warned, despite victories over Germany and Japan, the twin scourges of war and tyranny were as threatening in 1946 as they had been in 1935. Churchill believed it likely, should the United States retreat into isolationism as it had following WWI, the peace for which the Allies had sacrificed would not survive. He insisted the United States and its English-speaking allies had an obligation to stand united and firm, to bring order and effectiveness to the United Nations, and to "preach what we practice"-freedom and the rights of man. In opposition, Churchill made clear, loomed the Soviet Union. ${ }^{10}$

Today, few Americans question how their forbearers reacted to this call to action. Their study of history and maturation during a period when conflict with the Soviets, sometimes "hot," more often "cool" or "cold," was normal convince them it was inevitable that the United States would remain engaged internationally following World War II (WWII). The Cold War touched nearly every aspect of their life and fashioned their perspective on the past. As economic and political circumstances changed at home, popular support for foreign aid and intervention waxed

\footnotetext{
${ }^{9}$ Winston Churchill, “The Sinews of Peace” (Westminster College, Fulton, MO, March 5, 1946), http://www.nato.int/docu/speech/1946/s460305a_e.htm (accessed September 3, 2013).

${ }^{10}$ Churchill, "The Sinews of Peace”; Jeremy Isaacs, "Episode 2: Iron Curtain, 1945-1947," disc 1, Cold War: The Complete Series, DVD, directed by Vivian Schiller et al. (Time Warner, 1998). Numerous historical references document the relative strengths and weaknesses of the Allies after their victory; they are unanimous in their description of the United States as the only power stronger at the end of the war than it had been at the start. Curt Cardwell, NSC 68 and the Political Economy of the Early Cold War (New York: Cambridge University Press, 2011), 38-40.
} 
and waned, but never did it evaporate as it had after World War I (WWI). Instead, between 1950 and 1990, the United States stationed at least one fifth of its armed forces overseas. It organized coalitions against the Soviets and their allies in all corners of the world, joined collective security agreements for the first time, and founded organizations like the Peace Corps and the Agency for International Development to improve the quality of life for millions. ${ }^{11}$

That the United States would bind itself to such commitments, however, was not so obvious immediately after WWII. When Churchill spoke, the American people were focused on "go[ing] to movies and drink[ing a] Coke," not on new threats to a hard won peace. Americans were ambivalent toward foreign affairs historically, but even more so in postwar periods. When polled, postwar Americans supported a generically active international role for the United States. The Senate echoed this sentiment when it voted, 89-2, in favor of the United Nations charter in July 1945. On the other hand, when asked about specific issues, like "dealing with Russia" or providing aid to Europe, Americans were decidedly less enthusiastic and poorly acquainted with the details. The 69-17 Senate vote to pass the Economic Recovery (i.e., Marshall) Plan in March 1948, closer than the vote on the U.N. charter and uncertain until the end, shows the relative lack of enthusiasm for concrete initiatives was not limited to the people. ${ }^{12}$

\footnotetext{
${ }^{11}$ U.S. Department of Commerce Census Bureau, Statistical Abstract of the United States: 2012 (Washington, DC: U.S. Government Printing Office, 2012), Sec 1 Table 7; Tim Kane, "Global U.S. Troop Deployment, 1950-2005," http://www.heritage.org/research/reports/2006/05/global-us-troop-deployment1950-2005 (accessed December 22, 2013). In 2010, there were 40 million Americans over the age of sixtyfive and 82 million under the age of twenty. The former arrived before the Cold War began and the latter after it ended. Almost a third of the population, those under twenty, never experienced the Cold War.

${ }^{12}$ Walter Isaacs and Evan Thomas, The Wise Men: Six Friends and the World They Made (New York: Simon \& Schuster, 1986), 19; Martin Gilbert, Churchill: a Life (New York: Holt Paperbacks, 1992), 865, 867-868; Isaacs, "Episode 2: Iron Curtain, 1945-1947," disc 1, Cold War: The Complete Series; Gabriel Almond, The American People and Foreign Policy (New York: Frederick A. Praeger, 1960), 7879; Walter A. McDougall, Promised Land, Crusader State: The American Encounter with the World Since 1776 (New York: Houghton Mifflin Co., 1997), 153; Harold L. Hitchens, "Influences on the Congressional Decision to Pass the Marshall Plan," The Western Political Quarterly 21, no. 1 (1968): 51-52, 56-57. The Marshall Plan vote may seem comfortably in favor, but the debate was close. The Soviet-sponsored communist coup d'état in Czechoslovakia (March 5, 1948) was the deciding motivator for many Senators.
} 
This lack of enthusiasm had three roots. First, having just ended a costly war, many Americans were uninterested in new conflicts. In fact, most were optimistic the United States would be at peace for a quarter century or more. After all, if not for lasting peace, for what had their men died? Second, Americans favored broad ideals, like "world peace," but demonstrated little interest in specific national security issues that were complex and frustrating. Finally, because the sacrifices of the Soviet people were a prominent theme of American wartime domestic propaganda it was initially difficult for the American people to view postwar relations pessimistically. In a January 1945 poll, more than seventy percent believed American-Soviet relations after the war would be better than they had been before the war. Most thought Soviet aims in Eastern Europe were defensive or humanitarian in nature; only twenty-five percent thought them malevolent. Most simply were not ready to consider the Soviets, an erstwhile and hardy ally, a vital threat. ${ }^{13}$

By early 1948, optimism about peace had faded into the pessimism that characterized the Cold War and inspired America's engagement in the world. A relentless stream of bad news and misunderstandings contributed: disagreements over Polish self-determination (1945), threats over the delayed withdrawal of Soviet forces from Iran (1946), limited progress on the conclusion of a permanent peace treaty (1945-1948), civil unrest in Greece, Italy, and France (1946-1949), and in February 1948, shock over a Soviet-sponsored communist coup d'état in Czechoslovakia. In a March 1948 poll, nearly three-quarters of those polled anticipated a major war, most likely between the United States and Soviet Union, within the next ten years. ${ }^{14}$

${ }^{13}$ Almond, 89 and 93-95; John E. Mueller, "Public Expectations of War During the Cold War," American Journal of Political Science 23, no. 2 (May 1979): 304.

${ }^{14}$ Ibid. In 1948, Italy was home of the largest communist party outside of the Soviet Union. The Czech coup was particularly upsetting to Washington and, coming as it did during the debate on the Marshall Plan legislation, was a factor in its successful passage. See Isaacs, Cold War: The Complete 
As the mood of the people changed, so too did that of the Truman Administration. How Truman managed this transition from war to peace to Cold War determined his foreign policy legacy. By mid-1948, there was consensus and a concept that would guide the United States for many years, but in the interim, there had been "intellectual and organizational agonies" to endure as policymakers "sought to understand and explain the changes taking place in the world." There were equally compelling arguments, made by men of great influence, for and against varying degrees of cooperation or confrontation with the Soviets. This chapter looks at those making those arguments and responsible for the final policy. ${ }^{15}$

\section{National Security during the Harry S. Truman Administration}

When Harry S. Truman became President eighty-two days into the fourth Roosevelt Administration, he was unacquainted with the details of the challenges facing the United States as the end of WWII approached. He possessed two decades of political experience, first as an elected judge in his home state of Missouri, briefly as an administrator for a federal works program, and most recently, ten years as a U.S. Senator, but he had barely had time to settle into his newest position - Vice President, when the President died. Unfortunately, Roosevelt, who largely managed foreign affairs on his own, had not seen fit to include Truman in the brief time they had together. Furthermore, Truman, described as lacking inquisitiveness, creativity, and decisiveness, apparently made no effort, despite Roosevelt's deteriorating health, to request briefings, form his own foreign policy team, or study emergent issues. Truman took office, "a parochial, ill-informed, impatient man ... [and] replaced a cosmopolitan, knowledgeable

Series, Episode III. A message from General Clay, Commander, U.S. Forces-Europe, on the coup d'état struck some as a "war warning." See Council of War: A History of the Joint Chiefs of Staff, page 74.

${ }^{15}$ Peter Grose, Continuing the Inquiry: The Council on Foreign Relations from 1921 to 1996 (New York: Council on Foreign Relations, 1996), 29. 
Roosevelt" precisely when the international system, recovering from six years of war, was evolving in dramatic and fundamental ways. ${ }^{16}$

What he lacked in experience, Truman made up for in conviction. An admirer of Woodrow Wilson, Truman took his oath of office under a portrait of the twenty-eighth president and sounded Wilsonian in his view of foreign affairs. He voted for the Neutrality Acts, but soon regretted those votes and argued against isolationism. He thought the Senate had been wrong to reject the League of Nations, and told voters in 1940 that the Fourteen Points were "just as good today as ever." He considered the Second World War an extension of the first and was determined that the United States, which he believed possessed moral superiority over other nations, could not retreat into isolationism. In 1943, Truman was the inspiration behind a Senate resolution calling upon the "United Nations to maintain world peace and stability after the war" and, in a multi-state tour, he advocated continued U.S. engagement and an international military force after the war. In this regard, his resolution predated Roosevelt's support for a standing international body. ${ }^{17}$

\footnotetext{
${ }^{16}$ Wilson D. Miscamble, From Roosevelt to Truman: Potsdam, Hiroshima, and the Cold War (New York: Cambridge University Press, 2007), ix-x, 10-11, and 30. Truman addresses Roosevelt's management style briefly in his Memoirs, first volume, pages 55-6. Others do as well. To offer a modicum of defense, the pair were inaugurated on January 20, 1945, Roosevelt almost immediately departed for Yalta to meet with Churchill and Stalin, did not return until late February, left for Warm Springs, Georgia in late March, and died several weeks later. Even if Roosevelt had wanted to work closely with Truman, and there is no indication he did, the two men were not physically together long enough to do anything substantive. It does not seem reasonable to assume that anyone thought Roosevelt would survive much longer. The war had aged him, Truman and others noticed the changes; in fact, changes were noticeable enough that the Inaugural Committee moved the swearing in venue to accommodate the ailing President. Both men should have done more to prepare for a transition.

${ }^{17}$ Miscamble, From Roosevelt to Truman: Potsdam, Hiroshima, and the Cold War, 14-15, 20-22, 32, and 39-40; Harry S. Truman, Memoirs by Harry S. Truman: Year of Decisions (Garden City: NY: Doubleday \& Company, 1955), 8 and 21. From Roosevelt to Truman: Potsdam, Hiroshima, and the Cold War is an interesting read on the transition from Roosevelt to Truman, focused on Truman. The Fourteen Points, proposed by Wilson in 1918, was a broadly idealistic statement of U.S. war aims in WWI. They established a policy of democracy, free trade and markets, transparency and open agreements between governments, and self-determination. Europe rejected most provisions. Even if having the Wilson portrait
} 
An ardent anti-communist, Truman nevertheless intended initially to adopt Roosevelt's foreign policy, including continued cooperation with the Soviets. His closest advisors, however, differed in their assessments of Soviet intentions and the future of American-Soviet relations. Some, like Ambassador Averell Harriman warned that Europe faced a "barbarian invasion" from the east while others, including Harry Hopkins, the Special Assistant to President Roosevelt, Ambassador Joseph Davies, and former Vice President Henry Wallace believed cooperation not only possible, but desirable. Truman favored Hopkins and Davies, but disagreements over the composition of the Polish government, structure and rules at the United Nations (U.N.) and the withdrawal of Soviet forces from Iran were "ominous," foreshadowing "more difficult times ahead." To Truman, it gradually became clear "that the whole world structure and order that we had inherited ... was gone and that the struggle to replace it would be directed from two bitterly opposed and ideologically irreconcilable power centers." 18

In February 1947, after a particularly harsh winter in Europe, events came to a head. With rationing at levels more severe than during the war itself, high unemployment, and daily electrical blackouts, industrial production in the United Kingdom seized. Until then, the United Kingdom had done its best to aid continental Europe, particularly the Germans, Greeks and Turks, but with

in the background was unintentional, it seems to have meant something to Truman; he mentions it in his Memoirs, page 8.

${ }^{18}$ John Lukacs, 1945: Year Zero (Garden City, NY: Doubleday and Co., 1978), 136-137; Truman, Memoirs by Harry S. Truman: Year of Decisions, 22-26; Wilson D. Miscamble, "Harry S. Truman, the Bomb, and the Transformation of U.S. Foreign Policy" (lecture, Florida Atlantic University, Boca Raton, FL, 2008), http://www.fau.edu/osullivan/images/Wilson_D__Miscamble_pub.pdf (accessed September 27, 2013); Dean Acheson, Present at the Creation: My Years in the State Department (New York: W.W. Norton \& Co., 1969), 726; Averell W. Harriman, America and Russia in a Changing World: A Half Century of Personal Observation (New York: Doubleday \& Co., 1971), 31-44. When the Germans invaded the Soviet Union, Truman said, "If we see that Germany is winning we ought to help Russia and if we see Russia is winning we ought to help Germany." Though not entirely serious, this comment reflected Truman's feeling towards the Soviets. Davies had been the Ambassador in Moscow from 1936-1938; Harriman served in the same position from 1943-1946. Wallace was extreme in his views, considered by many to be pro-communist, and though he served briefly as Secretary of Commerce for Truman, he became a vocal critic and departed government service embittered. 
gold reserves exhausted and its economy on the brink of collapse, the British informed the State Department they could no longer provide economic aid to Greece and Turkey. This was particularly worrisome for the Greek government was then fighting a civil war with communist militants. Without aid, the United States and United Kingdom feared the communists would overwhelm the freely elected Greek government as they had others throughout Eastern Europe. Stunned, the Truman Administration realized that with this announcement the British had "handed the job of world leadership, with all its burdens and glory, to the United States."19

Over the next four months, U.S. foreign policy undertook a "complete conversion" that represented "democracy working at its finest, with the executive branch of the government operating far beyond the normal boundaries of timidity and politics, the Congress beyond usual partisanship, and the American people as a whole beyond selfishness and complacency." Truman and his primary staff seized upon the seriousness of the situation, immediately reached out to Congressional leadership, and took their proposals to the public. Previously, Secretary of State George C. Marshall had described the American people as "relaxed"; now they began the most expansive and expensive national security initiative the United States had taken outside of war. ${ }^{20}$

${ }^{19}$ Acheson, Present at the Creation: My Years in the State Department, 212 and 219-220; Joseph M. Jones, The Fifteen Weeks (New York: Viking Press, 1955), 139-142. In late 1946, for example, the British provided \$1 million per day to feed, clothe, and heat the Germans, their former enemies. Jones' Fifteen Weeks is an exceptional accounting of the period from February 21 to June 5, 1947.

${ }^{20}$ Jones, 8; George C. Marshall, "Alumni Day Message” (speech, Princeton University, Princeton, NJ, February 22, 1947), http://blogs.princeton.edu/paw/files/import/i-4a2781582f2ac16b06e4b70ee1363f4george_marshall_AlumniDay.pdf (accessed March 9, 2014). The day after the British note arrived, Marshall said: "Now that an immediate peril is not plainly visible, there is a natural tendency to relax and to return to business as usual .... But I feel that we are seriously failing in our attitude toward the international problems whose solution will largely determine our future .... The war years were critical . . . but I think the present period is, in more respects, even more critical ... the more serious aspect is the fact that we no longer display that intensity, that unity of purpose, with which we concentrated on the war task and achieved the victory." For a discussion on how popular opinion influenced passage of the Marshall Plan, see Hitchens, "Influences on the Congressional Decision." 
On March 12, 1947, Truman addressed a Joint Session of Congress. Quickly getting to the point, he told his audience the United States had received a request for immediate financial and economic assistance from the Greek Government. Its peoples had endured invasion, a brutal occupation, and deprivation only to find at liberation a "militant minority, exploiting human want and misery" to create chaos when there should be peace. The Greeks had neither the ability to sustain themselves nor the funds to import basic goods essential to their survival. Their army, small and ill equipped, could not preserve order. Saying the United States alone could help, he told Congress the British were ending their aid and the U.N. would not be able to act in time. The situation was dire. ${ }^{21}$

After describing a similar, if less severe, situation in Turkey, Truman made a clear statement on U.S. national security objectives. The United States, he said, had just fought a war against two countries who sought to impose their will on others. It had taken a leading role in establishing the United Nations (U.N.) to secure that peace. It could not realize its objectives, however, unless the American people were "willing to help free people to maintain their free institutions." Aggressive movements that sought to impose their will on free peoples, like the Greeks, "undermine the foundations of international peace and hence the security of the United States." Already, in the last year, the United States had lodged protests over coercion and intimidation in Poland, Romania, and Bulgaria as each had their sovereignty violated and minority systems of government imposed. It could not let the same happen to Greece; if it did, Turkey could be next and then "disorder might well spread throughout the entire Middle East." "It must be," Truman continued, "the policy of the United States to support free peoples who are

\footnotetext{
${ }^{21}$ Harry S. Truman, “Aid to Greece and Turkey,” Vital Speeches of the Day 13, no. 11 (1947): 322323, http://vsotd.com/speech-archive (accessed March 9, 2014). Four events define the Truman national security legacy. They are: this speech (and subsequent Marshall Plan); the establishment of the modern national security apparatus (discussed in a later section); the fall of Nationalist China to the communists; and the Korean War.
} 
resisting subjugation ... primarily through economic and financial aid which is essential to economic stability and orderly political processes."22

Before Congress could complete its debate and act, the Administration realized the crisis in Europe extended well beyond Greece and Turkey. To set the stage for a larger aid package, one to help the whole of Europe, Undersecretary of State Dean Acheson travelled to Mississippi on behalf of the President to deliver "a major foreign policy speech" that foreshadowed the keynote speech Secretary of State George Marshall delivered a month later. Saying U.S. aid "[was] only in part suggested by humanitarianism," Acheson acknowledged that lasting peace and prosperity for the United States was not possible until Europe overcame the grim circumstances in which it found itself. It could not sustain itself, yet could not generate sufficient exports to match the rate at which it imported American goods. Already poor economic conditions were on the verge of collapse and the lack of confidence would likely sink any attempt free Europe made to recover. ${ }^{23}$ Acheson proposed that the United States remove trade barriers to increase imports, increase financing of foreign purchases, revive agricultural and industrial capabilities so countries could sustain themselves, rebuild the economic engines of Europe and Asia (i.e., Germany and Japan), and extend wartime emergency powers granted the President to manage the sale, transportation, and exportation of some goods. Only these steps, he argued, could broaden the narrow margins of economy, dignity, freedom and democratic institutions then present across

${ }^{22}$ Ibid, 323. Greece, Turkey, then Middle East, a hint perhaps of the domino theory "introduced" by the Eisenhower Administration in 1954. Truman argued that the $\$ 400$ million he requested was a wise investment against the $\$ 341$ trillion spent during WWII. If a small amount of aid preserved that victory and prevented the larger expense of a future war, it was wise.

${ }^{23}$ Dean Acheson, "The Requirements of Reconstruction," Vital Speeches of the Day 13, no. 16 (1947): 485-486, http://vsotd.com/speech-archive (accessed March 9, 2014); Acheson, Present at the Creation: My Years in the State Department, 229. Congress passed the aid package for Greece and Turkey on May 22, two weeks after Acheson spoke about more to come. Senator Arthur Vandenberg anticipated a new request and was not supportive so Marshall promised he would not introduce it during that session of Congress. At the Creation, 230. 
Europe. He concluded, "[they are] necessary if we are to preserve our own freedoms and our own democratic institutions. It is necessary for our national security. And it is our duty and our privilege as human beings. ${ }^{24}$

Then, on June 5, at Harvard University, Marshall introduced Americans, Europeans, and the Soviets to the ideas that became the Economic Recovery Plan (ERP), i.e., the Marshall Plan. Echoing a radio address given after his visit to Europe that spring and drawing on a pessimistic description of European recovery written by the State-War-Navy Coordinating Committee, Marshall said Europe lay trapped in a cycle of misery that sapped its confidence and belief in the future. Without U.S. assistance there could be no economic recovery, "no political stability and no assured peace." Avoiding the anti-communist rhetoric he found disagreeable in the Truman speech, Marshall said this initiative targeted "hunger, poverty, desperation, and chaos" not a specific country or ideology. Any country, he insisted, willing to assist the recovery effort, would find itself aided by the American people. On the other hand, "political parties or groups which seek to perpetuate human misery" for political profit or to disrupt the "emergence of political and social conditions in which free institutions can exist" would find the United States in opposition. Marshall never mentioned the Soviets or communism, but the implication was clear. ${ }^{25}$

\footnotetext{
${ }^{24}$ Acheson, "The Requirements of Reconstruction," 487. Human suffering and political freedom in Europe were powerful motivators behind the Marshall Plan, but multiple authors make a compelling argument that American economic security and prosperity, the "dollar gap" between American industrial capacity and the ability of others to pay, were equally compelling reasons to put dollars into European hands. See Jackson, "Prologue to the Marshall Plan," and Cardwell, NSC 68 and the Political Economy of the Early Cold War.

${ }^{25}$ United States Department of State, Foreign Relations of the United States, 1947: The British Commonwealth; Europe, Vol. III (Washington, DC: U.S. Government Printing Office, 1947), 204-219; George C. Marshall, "European Unity," Vital Speeches of the Day 13, no. 18 (July 1, 1947): 553-554. In his radio address, Marshall told the public "the patient is sinking while the doctors deliberate ... action cannot await compromise through exhaustion." It was time for the United States to do more to assist in Europe's recovery. See Acheson, Present at the Creation, 228. Marshall told the White House he opposed the anticommunist tone of the Truman speech, they told him that Truman believed the legislation to support Turkey and Greece would only pass if Congress and the people were scared. See Bryan, 492. Though ERP
} 
The reaction to the speech was largely positive. According to a poll taken several weeks later, the American people were amenable to helping countries still suffering the effects of the war. In Europe, British Foreign Secretary Ernest Bevin and French Foreign Minister Georges Bidault embraced the opportunity to develop a plan the United States could support. They assembled a conference of sixteen nations to assess the needs of each and presented a request for $\$ 22$ billion. The Soviets initially attended the conference, but withdrew over opposition to political and economic reforms they believed the United States expected in exchange for loans or grants it provided. Eastern European nations, under pressure from the Soviets, also declined to participate and joined the Soviet Union in an alternative program — the Council for Mutual Economic Assistance. ${ }^{26}$

The legislation Truman submitted to Congress was $\$ 5$ billion less than the European request, but that did little to ease the opposition it faced. How Truman overcame this opposition is a topic for a later section, but overcome it he did. When ERP became law in April 1948, the United States embarked on a five-year program that committed over $\$ 12$ billion to Western Europe within a larger $\$ 44$ billion global aid program. A commitment this substantial, executed to fulfill the broader objectives of the Truman speech, now known as the Truman Doctrine, firmly placed isolationism in the past and marked a commitment to engagement and leadership not

did not exclude any country, the State Department never believed the Soviets would accept or allow their neighbors to accept.

${ }^{26}$ Ferald J. Bryan, "George C. Marshall at Harvard: A Study of the Origins and Construction of the 'Marshall Plan' Speech," Presidential Studies Quarterly (Summer 1991): 499; Isaacs, "Episode 3: Marshall Plan, 1947-1952," disc 1, Cold War: The Complete Series. Czechoslovakia and Poland accepted the invitation to the conference and wanted to accept aid, but Stalin ordered them to decline. Hungary, Bulgaria, and Romania immediately rejected invitations to the conference and for aid. Finland was inclined to accept, but though it was not a communist state, declined to avoid upsetting the Soviets. 
seriously questioned for four decades. It was only one of several paths the United States could have chosen at the time. ${ }^{27}$

\section{Major Ideas of the Post-War Period}

Truman and Marshall leant their names to the major initiatives they promoted, but the origins of their ideas lay with other men. Amongst these, George F. Kennan is the most prominent. Kennan entered the foreign service in 1925 and then studied Russian literature, history, particularly constitutional and legal history, and economic geography at the University of Berlin. Upon completion of his studies, he received a posting in the American Legation in Riga, Latvia, the office that managed Soviet-American affairs since the United States had not yet established relations with the Soviet Union. Exposed to "prolonged and incessant ... hammerblow impressions" of Stalinist tyranny, "each more outrageous and heartrending than the other," Kennan viewed the Soviets with suspicion long before the State Department in general shared those feelings. When Roosevelt recognized the Soviet Union in 1933, largely to offset growing concern about Germany and Japan, Kennan disagreed, saying he did not then "nor at any later date ... consider the Soviet Union a fit ally or associate, actual or potential, for this country." 28

\footnotetext{
${ }^{27}$ United States Department of Commerce, Statistical Abstract of the United States: 1954 (Washington, DC: Government Printing Office, 1954), 899. ERP, i.e., the Marshall Plan, only provided aid in the form of loans, grants, or credits to Western Europe. Simultaneously, the United States had aid programs supporting other regions of the world. It is also worth noting the United States had spent $\$ 15$ billion on European recovery before the Marshall Plan. Admittedly, American commitment to engagement waxes and wanes, but generally, those referred to as isolationists of the last sixty years are not in pursuit of the same type of isolationism sought by some in the interwar years.

${ }^{28}$ George F. Kennan, Memoirs: 1925-1950 (Boston: Little \& Brown, 1967), 23, 30-33, 57, and 6870. Kennan is the source of numerous books, monographs, and research papers. Amongst these, George F. Kennan: An American Life, by John Lewis Gaddis, is the only biography authorized by the subject. Walter Isaacson and Evan Thomas, in their book The Wise Men, relate the story of four other key players - Charles Bohlen, Averell Harriman, Robert Lovett, and John McCloy - bound by common experiences as youth, in college, and in the Foreign Service. They formed, with Acheson and Kennan, a team of individuals uniquely familiar with each other. They were the "architects of the American century" responsible, as future Secretary of State Henry Kissinger would say, for a "burst of creativity [which] is one of the glorious moments of American history."
} 
In late 1936, Kennan, posted to the new U.S. Embassy in Moscow, wrote his first paper on the Soviet Union and described its pursuit of peace with non-communist governments as a "provisional abnormality — an armistice or breathing space between conflicts." Stalin, he argued, would let others - Germany, France, and Britain — fight and then gather what remained. About a year later, Kennan observed that Americans had a great deal in common with the Russian people, but the Soviet government was so fearful it would lead to a future of "misunderstandings, disappointments, and recriminations on both sides." Before the war, he supported Ambassador James Bullitt's firm stance with the Soviets, believing strength and force was what the Soviets appreciated, and thought Bullitt's successor, Joseph Davies possessed sympathies that unjustifiably fed optimism about American-Soviet relations. Even wartime cooperation did not allay his concerns; Kennan believed there were simply far too many areas in which the Allies had little in common for the alliance to survive the peace. ${ }^{29}$

In February 1946, when the Treasury Department asked why the Soviets were not supporting the World Bank and International Monetary Fund initiatives, Kennan, frustrated earlier messages had apparently fallen on deaf ears, sent a carefully constructed response later known as the "Long Telegram." He described the Soviet outlook and its origins, how they influenced Soviet policies, officially and unofficially, and how the United States should respond. The Soviets, he wrote, were ideologically motivated opportunists, not adventurists, and though not subject to reason, were vulnerable to vigorous, united political opposition. The task of dealing

\footnotetext{
${ }^{29}$ Kennan, Memoirs: 1925-1950, 70-74, 80-83, 175-179, 225, 253, and 255-256; United States Department of State, Foreign Relations of the United States, 1944, Europe. Vol. IV (Washington, DC: U.S. Government Printing Office, 1944), 902-914. His papers included "War Problem of the Soviet Union" (1936-1937), "Russia-Seven Years Later" (1944), and "Russia's International Position at the Close of the War with Germany" (1945). Kennan predicted the United States and Soviet Union would disagree on a wide array of issues including reparations, war crimes tribunals, denazification, and administration of liberated territories. He was convinced American postwar plans were reliant on "dangerous misreadings of the personality, the intentions, and the political situation of the Soviet leadership."
} 
with the Soviets, who did not themselves believe cooperation with the United States was possible, was "undoubtedly [the] greatest task our diplomacy has ever faced and probably greatest it will ever have to face.” Kennan advocated a response built upon setting an example for the world, public education, and strengthening of liberal democratic values lest "we shall allow ourselves to become like those with whom we are coping." 30

Arriving in Washington two weeks after Stalin himself had said confrontation between the Soviet Union and the West was "inevitable," the Telegram resounded within the Truman Administration. Stalin's speech had been "grim news," depressing "even the ebullient spirits of Secretary [of State James] Byrnes.” Kennan's telegram “depressed [the mood] even further" and had a "deep effect on thinking within the government." Truman immediately ordered Clark Clifford, the White House Counsel, to conduct a whole-of-government study called American Relations with the Soviet Union. Finished in September 1946, it too painted a dim view of future relations. Truman had not yet lost all hope he could find compromise with the Soviets, so he ordered it suppressed saying, "This is so hot ... it could have an exceedingly unfortunate impact on our efforts to try to develop some relationship with the Soviet Union." 31

With the Telegram raising his profile to a level noted by senior government officials, Kennan soon found himself reposted from the Embassy to Washington, D.C. He served at the National War College for a year until Marshall selected him as Director of the newly formed

\footnotetext{
${ }^{30}$ Kennan, Memoirs: 1925-1950, 293; George Kennan, "Telegram to the Secretary of State" in Foreign Relations of the United States, 1946. Eastern Europe, the Soviet Union, by the United States Department of State (Washington, DC: Government Printing Office, 1946), 696-709. The "Long Telegram" earned its name precisely because, at five thousand words, it was an exceptionally long cable. Kennan seems to have preferred the United States be a "promised land" rather than a "crusader state," to steal a phrase from Walter McDougall. Truman disagreed.

${ }^{31}$ Acheson, Present at the Creation: My Years in the State Department, 151; U.S. Office of the Special Counsel, White House, American Relations with the Soviet Union, by Clark Clifford (Washington, DC, 1946); James Schnabel, History of the Joint Staff: The Joint Chiefs of Staff and National Policy 19451947, Vol. 1 (Washington, DC: Office of the Joint Historian, 1996), 50; Margaret Truman, Harry S. Truman (New York: William Morrow \& Co., 1973), 347.
} 
Policy Planning Staff (PPS). Marshall charged Kennan to draft a plan for the recovery of Europe and relied on his counsel as he prepared for his address at Harvard. Their close working relationship — their offices were adjoining—-fed speculation that Kennan's first public work, an essay entitled "Sources of Soviet Conduct" [hereafter "Sources"] represented official policy. ${ }^{32}$

Published under a pseudonym in the July 1947 volume of Foreign Affairs, "Sources" largely reiterated in the public domain arguments made privately by Kennan in the past. They were arguments with which Truman and Marshall could relate, but which they were not ready to state so unequivocally. Congress had approved aid for Greece and Turkey only two months before, it was not ready to consider more aid. Marshall himself promised there would be no more requests for aid that Congressional session. "Sources," however, described a policy of "long-term, patient but firm and vigilant containment of Russian expansive tendencies" that suggested the Administration held grandiose plans for the future. Inadvertently, Kennan gave the Truman Doctrine another name — containment — and fueled criticism by notable public figures. ${ }^{33}$

First amongst those was Walter Lippmann a widely read and respected journalist for the New York Herald Tribune. Lippmann was a former Wilsonian idealist who by the end of WWII

\footnotetext{
${ }^{32}$ Kennan, Memoirs: 1925-1950, 354-357; Acheson, Present at the Creation: My Years in the State Department, 214; United States Department of State, Foreign Relations of the United States, 1947: The British Commonwealth; Europe, 220-223 and 223-230. At the National War College, Kennan was Deputy [to the Commandant] for Foreign Affairs and a lecturer on international policy. George F. Kennan, Measures Short of War: The Kennan Lectures at the National War College, 1946-47 (Washington, DC: Sold by the Supt. of Docs., U.S. G.P.O, 1991) is a collection of his lectures. Marshall formed the PPS to "look ahead, not into the distant future, but beyond the vision of the operating officers . . . to see the emerging form of things to come and outline what should be done." It is a lasting organizational impact of Marshall's service in the Department. As for Kennan representing policy, it is important to note that Kennan rejected those portions of the Truman Doctrine that implied a global commitment. He never agreed that "Sources" and the Truman speech together represented the same policy; technically, he is correct, as containment is a policy subordinate, not equal, to the notion behind the Truman Doctrine. "Sources" began as a private memorandum, "The Psychological Background of Soviet Foreign Policy," Kennan wrote for Secretary of the Navy James Forrestal. Kennan spoke on the same topic at the Council on Foreign Relations and when they requested he publish his speech, he revised this memorandum for publication.

${ }^{33}$ George F. Kennan "Source of Soviet Conduct," Foreign Affairs 65, no. 4 (Spring 1987): 861; Hitchens, 64. Kennan relates Marshall's firm, but calm reaction to "Sources" in his Memoirs.
} 
had embraced foreign policy positions decidedly more accepting of balance of power, spheres of influence, and realpolitik than the Fourteen Points had allowed. By the time Kennan "introduced" the term containment in "Sources," Lippmann had already written two books calling for post-war cooperation with the Soviets and rejecting a return to the "cordon sanitaire" policy of the interwar period. That policy, initiated by French Prime Minister Georges Clemenceau in 1919, attempted to isolate the fledgling Soviet Union geographically with a belt of anti-Soviet states in Eastern Europe. Lippmann believed it "not only unavoidable but eminently proper that each great power does have a sphere in which its influence and responsibility are primary." For the Soviets, this sphere lay in Eastern Europe and the United States, Lippmann argued, was not respectful enough of Soviet interests if it resisted the establishment of a sphere that would alleviate Soviet fears. Spheres of influence were normal, Lippmann thought, the United States having "its own - not only in Latin America, where undemocratic regimes thrived, but also in Japan, where it had locked out the Soviets [of planning for post-war occupation]." 34

Lippmann had no special affinity for the Soviets and favored aid for Europe, but he felt the Administration had set upon a policy that tied it too closely to the British, marginalized the United Nations, and set the United States on an unsustainable and dangerous path. Diversity, he had once said, demanded mutual respect and an "equilibrium of power" enforced by international law, embodied in the United Nations. Neither key policy statements made by the Administration

\footnotetext{
${ }^{34}$ Mark A. Stoler, Allies and Adversaries: The Joint Chiefs of Staff, the Grand Alliance, and US Strategy in World War II (Chapel Hill, NC: University of North Carolina Press, 2000), 32 and 57; Ralph E. Weber, ed. Talking with Harry: Candid Conversations with President Harry S. Truman (Wilmington, Delaware: Scholarly Resources, 2001), 270n; Ronald Steel, Walter Lippmann and the American Century (Boston: Atlantic Monthly Press, 1980), 405, 408-409, and 426. Lippmann organized the Inquiry, a postWWI advisory group to President Wilson and Colonel Edward M. House, and helped draft the Fourteen Points. Marshall read Lippmann, acknowledging his views on troop concentrations before the war. According to Acheson, Truman offered Lippmann a position in the State Department public affairs division; Lippmann declined. See Present, 120. It is just as well for Truman, in Talking with Harry, 266-8 and 270, expresses negative feelings towards Lippmann. Conservative estimates places the reach of his column at nearly 38 million Americans, one fourth of the population. Clearly, he was well known. The books referred to are U.S. Foreign Policy: Shield of the Republic (1943) and U.S. War Aims (1944).
} 
about aid to Europe nor "Sources" articulated a role for the United Nations. Truman alone mentioned the U.N. and then only to discredit its ability to work at the pace he required. Shortly after Lippmann learned that Kennan had written "Sources," he began a series of columns later republished in a book, The Cold War: A Study of U.S. Foreign Policy. ${ }^{35}$

Lippmann agreed the Soviets posed a threat, but called the Truman Doctrine "fundamentally unsound" and infeasible, warning "the attempt to make it work will cause us to squander our substance and our prestige." He rejected Kennan's optimism that the United States could contain the Soviet Union until it collapsed or changed on its own, alleged containment ceded the initiative to the Soviets, and argued that it could not work unless the United States and its allies "get all the breaks." Suggesting neither the State nor Defense Departments had then or ever would have the resources to execute containment globally, Lippmann said it would be essential to build a costly broad coalition of friendly satellite states, but cautioned that such a coalition could not survive long enough to complete a "lengthy siege of the Soviet Union." The United States, Lippmann wrote, had made guarantees, particularly to Eastern Europe, it could not enforce by any means. The only solution was to conclude the treaties required to formally end the war and then use those treaties to exert pressure on the Soviets or expose their intentions. ${ }^{36}$

Senator Robert A. Taft (Ohio) also opposed the new Truman Doctrine, albeit for different philosophical reasons. Nicknamed "Mr. Republican," Taft, a one-time and future presidential

\footnotetext{
${ }^{35}$ Scott Jackson, "Prologue to the Marshall Plan: The Origins of the American Commitment for a European Recovery Plan," The Journal of American History 65, no. 4 (March 1979): 1051; Steel, 429; Walter Lippmann, "One World of Diversity," Vital Speeches of the Day 13, no. 5 (December 15, 1946): 138-40; Walter Lippmann, The Cold War: A Study in U.S. Foreign Policy (New York: Harper Brothers Publishers, 1947), 9-10. Lippmann had concerns about the Soviets, particularly their unwillingness to reduce the size of their military presence in Eastern Europe. He also distrusted the British, telling his readers after the Churchill speech in March 1946, "British Imperial interest and the line of American vital interest are not regarded as identical." Lippmann felt the Churchill speech would trigger a hostile response from the Soviets and an arms race between the United States and Soviet Union.
}

${ }^{36}$ Lippmann, The Cold War: A Study in U.S. Foreign Policy, 10, 21-23, and 44. 
candidate, led a conservative, anti-interventionist wing of his party that consistently challenged Roosevelt and Truman on domestic and foreign policy issues. Incorrectly labeled an isolationist, Taft held a complex array of views that were simultaneously continentalist, internationalist, and grounded in respect for justice. He believed defense of the United States began and ended in the Western Hemisphere, understood the economy needed foreign markets, and felt peace was reliant on the institutionalization of international law in a global body and world court. Above all, however, he fiercely protected American sovereignty and repeatedly said the United States fought not to spread democracy or free other peoples, but to "secure the blessing of liberty to ourselves and our posterity." ${ }^{37}$

Accordingly, Taft consistently opposed grants and unsecured aid to the Allies before the United States entered the war, voted for the United Nations Charter despite misgivings that its charter established an "arbitrary force of great powers and looks away from international justice," and supported some direct loans to Europe because they stabilized those economies for U.S. exports. Similarly, Taft rejected the Truman Doctrine and his support for the Marshall Plan was lukewarm. He thought military aid to Greece, a component of the package Truman requested, would incite the Soviets to increase support to communists in Western Europe. He took issue with the ERP on three points. First, he thought the cost to high and lacking consideration for the taxpayer, second, he expected the loans would fail to stimulate production, and third, he disagreed

\footnotetext{
${ }^{37}$ Acheson, Present at the Creation: My Years in the State Department, 95-96; Clarence E. Wunderlin, Robert A. Taft: Ideas, Traditions, and Party in U.S. Foreign Policy (Lanham, MD: Rowman \& Littlefield Publishers, 2005), 4; Robert A. Taft, "A Post-War Peace Organization of Nations," Vital Speeches of the Day 10, no. 16 (June 1, 1944): 492. Taft told Acheson, "the purpose of an opposition is to oppose." Acheson reflected, "oppose he did." Taft could have been Senate Majority Leader in the Eightieth Congress (1947-1949), but declined, choosing instead to serve as Chairman, Republican Policy Committee; this decision allowed Vandenberg to become Majority Leader. Taft was the leading candidate for the Republican nomination for president in 1952, but his lack of support for the North Atlantic Treaty Organization convinced Dwight D. Eisenhower to run. Eisenhower ultimately won the nomination and the general election, becoming President in 1953. Wunderlin, 159-160.
} 
with provisions of the program that encouraged political reform. The United States, he argued, should promote democracy by its example, not by exporting institutions and values to others. ${ }^{38}$

If Lippmann occupied the center of dissent and Taft the right, Henry Wallace occupied the left. Harshly labeled a "radical appeaser," but preferring the title "progressive" himself, Wallace, a former Vice President (1941-1945) and sitting Secretary of Commerce, strenuously and publicly challenged Truman's new approach to American-Soviet relations. On September 12, 1946, Wallace expressed suspicion of the British beyond what Lippmann voiced, warning if the United States were not careful, it would find itself in a new war between these "false friends ... [who] have no real love of the U.S." and the Soviets. Wallace rejected "balance of power manipulations," economic nationalism, and "get tough with Russia" policies the Administration adopted. Cooperation with the Soviets was preferable and possible, Wallace thought, once the United States established itself not as a defender of the United Kingdom, but as an unbiased arbiter between all. The choice, he said, was not whether the America would live in one world or two, but whether it would live at all. A week later, Truman asked Wallace to resign. ${ }^{39}$ An outsider throughout the critical year of 1947, Wallace was no less critical of Truman and the path he had chosen. The day after Truman spoke to Congress on aid to Greece and

${ }^{38}$ Wunderlin, 4, 33-34, 36, 109, 123, and 125-126; Hitchens, 56. Taft supported the Neutrality Acts of 1935, 1936, 1937, and 1939, opposed the Lend-Lease Act that effectively ended neutrality in 1941, and vigorously opposed the decision in 1946 to waive British repayments of wartime loans. He was supportive of deals in which the U.S. received cash or raw materials in exchange for aid. Anything else was a gift. His affinity for the rule of law and equal application of justice cannot be understated. Despite his conservative credentials, he questioned the legality of the steps President Theodore Roosevelt took to secure the Panama Canal Zone and was in the minority who opposed the internment of Japanese-Americans after Pearl Harbor. Fiercely partisan, he was a man of strong principles whether they be popular or not.

${ }^{39}$ Almond, 195-197; Henry Wallace, “The Way to Peace," Vital Speeches of the Day 12, no. 24 (October 1, 1946): 738-41; John M. Blum, ed., The Price of Vision: The Diary of Henry A. Wallace (19421946) (Boston: Houghton Mifflin Co., 1973), 558. Even Roosevelt, a quintessential liberal, but a politician first, understood Wallace represented a part of the Democratic Party too liberal for the electorate so swapped Truman for Wallace before the 1944 election. This decision is significant. It seems likely, had Wallace become President when Roosevelt died, American-Soviet relations would have looked different. 
Turkey, Wallace spoke out against it. Similarly, though he favored humanitarian aid to Europe, he thought the Marshall Plan would divide Europe between two warring camps. Wallace insisted the Truman approach, reliant on American relief agencies, not the U.N., sought the isolation, not inclusion of the Soviet Union and could not succeed. His sense that there were no real differences between Truman and the Republicans, both of whom stood for policies which opened the door to war, led him to run for President in 1948 on a third party ticket. He did not win-acceptance of an endorsement offered by the American Communist Party in the midst of the Berlin crisis did not help — but the small percentage of voters he received show that at least some portion of the electorate shared his views. ${ }^{40}$

No study on prominent ideas of the period would be complete without noting the role of think tanks. Operating outside the government, the Council on Foreign Relations (CFR) and its peers are not a part of official policymaking. Despite this lack of status and to the discomfort of critics, the relative influence of think tanks grew steadily from the onset of WWII well into the Cold War years. Who these organizations were, how they perpetuated influence and how they shaped decisions are important questions to the study of American policymaking. ${ }^{41}$

The Council on Foreign Relations (CFR) emerged in 1921 from a group of academics, nicknamed the Inquiry, gathered by President Woodrow Wilson to study the post-WWI international order. Led by Colonel Edward House, a close Wilson advisor, and organized by

\footnotetext{
${ }^{40}$ Jones, 174-178; Acheson, Present at the Creation: My Years in the State Department, 224; Henry Wallace, "I Shall Run in 1948," Vital Speeches of the Day 14, no. 6 (January 1, 1948): 172-74. Ironically, Acheson believed, when Wallace spoke against the Marshall Plan from his London office and not from within the United States, he did more harm than good for his cause. Granted, Wallace ran on a platform containing domestic and national security positions, but in announcing his candidacy in late 1947, he focused on national security policy.

${ }^{41}$ For a critical perspective on think tanks see Laurence H. Shoup and William Minter, Imperial Brain Trust: The Council on Foreign Relations and United States Foreign Policy (Lincoln, NE: Authors Choice Press, 2004). Those sharing the perspective of this book believe think tanks are elitist, opaque, and in possession of an unjustifiably substantial degree of influence. They would not be entirely wrong.
} 
Walter Lippmann, the President had charged the Inquiry to conduct a "systematic study ... to guide the statecraft of policymakers." This pool of "sheer, startling genius" drafted the Fourteen Points championed by the President and accompanied him to the Peace Conference in 1919. Wilson was unsuccessful convincing Europe to adopt the Fourteen Points in toto, but influence achieved by the Inquiry foreshadowed the future of the CFR. ${ }^{42}$

After the war, Elihu Root, a respected statesman and then Chairman of the Carnegie Endowment for International Peace, gathered a group of 108 lawyers and financiers who met in New York periodically to host dinners and meet foreign dignitaries. Interest waxed and waned until the group formally organized itself as the CFR and adopted as its mission the enabling of a "continuous conference on international questions affecting the United States." Holding nonattributional meetings, they believed the "right public opinion was mainly produced by a small number of people in real contact with the facts, who had thought out the issues involved." The men saw themselves as that "small number" and carefully selected its members from business, civic, and political elites. Proud of its religious, ethnic, and professional diversity, for years the Council included no women or African-Americans. ${ }^{43}$

In addition to hosting speakers and conducting quiet debates on issues of national and international import, the CFR published a quarterly, Foreign Affairs. In the lead article of the first edition, published in September 1922, Root, an internationalist, told his readers the United States

\footnotetext{
${ }^{42}$ Grouse, Continuing the Inquiry, and Wala, The Council on Foreign Relations and American Foreign Policy in the Early Cold War, are the primary sources of historical information on the CFR. Some of the more recognized think tanks, by date of establishment with ranking (media citations), and orientation include: The Carnegie Endowment for International Peace (1910, \#18, centrist), Brookings Institution (1916, \#1, centrist), Hoover Institution (1919, \#14, conservative), Century Foundation (1919), CFR (1921, \#5, centrist) American Enterprise Institute (1938, \#3, conservative), Rand Corporation (1946, \#10 centrist), Center for Strategic and International Studies (1962, \#9, conservative) and Heritage Foundation (1973, \#2, conservative). Source: Fairness and Accuracy in Reporting, Think Tank Spectrum 2012, dated July 02, 2013, at http://fair.org/extra-online-articles/fair\%e2\%80\%88study-think-tank-spectrum-2012/.

${ }^{43}$ Grose, 9 and 226-227. Council members were predominately from the East Coast (62\%), Ivy League alum (about 50\%), and members of the social register, i.e., the upper social strata (37\%).
} 
could not return to its isolationist past. It was time, he wrote, for Americans to recognize the nation had international responsibilities and to discover where their interests lay. To that end, he called for greater "popular education in international affairs." Root sought to provide this education indirectly, providing "information, solidly based opinion, and analysis" to those who formed public opinion and political debate. Foreign Affairs exposed its readers to a steady stream of prestigious contributors - statesman, dissidents, and political figures from home and abroadwhile simultaneously, if unofficially, promoting internationalism. ${ }^{44}$

While Foreign Affairs helped shape the policy debate outside the government, the Council influenced debate within government in two key ways - relationships and research. Because it and the government recruited from the same universities and social circles, inevitably they also recruited from each other. John McCloy said, "Whenever we needed a man, we thumbed through the roll of Council members and put in a call to New York." In 1945, fourteen of one hundred twenty-two senior Administrations officials were members of the Council; by 1955, the number had increased to forty-six of one hundred twenty-two. Former government officials rotated into the CFR routinely. McCloy himself followed a distinguished tour in government with one as Council Chairman. Dwight Eisenhower, between tours as Chief of Staff of the Army and Supreme Allied Commander Europe, was on the Council and led a study group that Joseph Kraft, a prominent journalist, believed taught the future president everything he understood about economics. $^{45}$

${ }^{44}$ Elihu Root, "A Requisite for the Success of Popular Diplomacy," Foreign Affairs 1, no. 1 (1922): 1; Michael Wala, The Council on Foreign Relations and American Foreign Policy in the Early Cold War. (Providence: Berghahn Books, 1994), 17-18 and 20-22. In 1927, Foreign Affairs had 11,000 subscribers. Today, it has about 170,000 subscribers. See Alliance for Audited Media, accessed December 18, 2013 at http://abcas3.auditedmedia.com/ecirc/magtitlesearch.asp. Members tended to define internationalism as an active engagement abroad, free trade, and secure access to materials and markets.

${ }^{45}$ Wala, 126-127 and 236. McCloy, Assistant Secretary of War under Henry Stimson, was, after the war, the second President of the World Bank and the U.S High Commissioner for Germany. 
Even if unintentional, the Council benefited from the relationships in place between members and government officials to gain "inside information." The State Department, meanwhile, used the CFR to test new ideas that "acting officially, itself would have been entirely too cautious to permit." In at least two notable cases-in opposition to the neutrality laws and in favor of the Marshall Plan-Council members advocated for a government unable to do so aggressively itself. In the latter, CFR members raised funds, held public meetings, formed local Committees of the Marshall Plan, and paid for radio broadcasts designed to inform the American people and motivate them to support the recovery effort. ${ }^{46}$

Equally useful were studies conducted by the CFR. Reflective of its roots in the Inquiry, at the outset of WWII, the Council began a "War and Peace Studies" initiative with the specific goal of assisting the Department of State. Though many members mobilized into the Department of State or Office of Strategic Services when the United States entered the war, War and Peace study groups met regularly throughout the war and secretly produced more than 600 policy memoranda for the State Department. In just one example, Secretary of State Edward Stettinus deemed Council advocacy, assistance, and participation in the Dumbarton Oaks and San Francisco Conferences on the United Nations “extremely important," even “very essential." 47

After accumulating more than 21,000 service hours during the war, the CFR reconfigured its study groups to focus on postwar issues-American-Soviet relations, reconstruction in Europe, and the effectiveness of policymaking processes. It recognized that "transformation did not occur without intellectual and organizational agonies" and it sensed the challenge Truman faced in dealing with the Soviets. Its Soviet Study Group led a contentious debate between members sympathetic to the Soviets and those more pessimistic. To its credit, it invited the Soviets to

\footnotetext{
${ }^{46} \mathrm{Ibid}, 36,64,173$, and 186-194.

${ }^{47}$ Grose, 23 and 39; Wala, 36.
} 
participate, but the Kremlin refused. Ultimately, the Group drafted a paper calling for "firmness coupled with moderation and patience." A majority of the group favored publication of the paper, but international events rapidly outpaced the debate and by late 1946, "all sympathy for a conciliatory stance" amongst Council members was dead. ${ }^{48}$

\section{The Congress and National Security Reorganization}

Wide-ranging opinions like those described above remained powerful ideas until they entered the policymaking structure, survived the rigors of internal debate and politics, bent to the necessities of compromise, and reemerged as policy in the form of a keynote speech, statement, or act of legislation. Just as the world these ideas sought to influence was changing, so too was the structure they navigated. Under Roosevelt, who lead the United States for twelve years, domestic and foreign policy resided in the hands of one man — the President — in possession of a substantial political mandate. Few believed the government could sustain this approach as it assumed a mantle of global leadership. Instead, the Congress, which took seriously its constitutional obligation for oversight, funding, and consent, legislated new national security organizations to help Truman and his successors lead the country into a new future. ${ }^{49}$

When the Eightieth Congress (January 1947-December 1948) took office, it marked the first time in fourteen years that Republicans controlled either house; now, they had control of both the Senate and the House of Representatives. The November 1946 election repudiated an unpopular president and empowered Republicans to repeal, defund, or restrain New Deal initiatives they had long opposed. Seeking less government, lower taxes and reduced spending, Republicans hoped to "get things done, go home, and give the people a breather." Time predicted,

\footnotetext{
${ }^{48}$ Grose, 29 and 32-35; Wala, 75 and 153-161.

${ }^{49}$ Roosevelt ran for president four times, winning all four, never by less than an eight percent advantage and never with less than 432 (of 531) electoral votes.
} 
on issues of foreign aid, the "Republican hand will not be as wide open as the hand of the last Democratic Congresses." The prediction was valid for only four months into the first session. ${ }^{50}$

The Congress contained views on foreign policy as diverse as those previously described so it would not be possible to detail them all. To describe the uniquely cooperative nature of the Eightieth Congress with the White House on national security issues, this section focuses on one of its more influential voices, Senator Arthur Vandenberg. He is notable for three reasons. First, Vandenberg was the senior Republican, a member of the opposition party who ascended to the Chairmanship of the Senate Foreign Relations Committee when his party gained control of the Senate. Second, Vandenberg, an isolationist most of his Senate career, abandoned those views during WWII. Finally, his peers, the legislative staff, the Administration, and the press respected Vandenberg for his leadership and nonpartisan approach to foreign policy. ${ }^{51}$

Vandenberg, a lawyer who spent his private career as a newspaper journalist, editor and publisher, initially entered the Senate in 1928 to fill a vacancy created by the death of his predecessor. He easily won election to a full term eight months later. He was studious and active in opposition to New Deal initiatives of the second Roosevelt Administration. By 1946, with seventeen years' experience on the Foreign Relations Committee, he was the spokesman for his Party on foreign affairs. Recognized and respected nationally, Vandenberg received votes towards nomination as a presidential candidate in 1940 and 1948, both times finishing fourth. ${ }^{52}$

${ }^{50}$ Time Editorial Board, “The Eightieth Congress,” Time (January 6, 1947): 19. The New Deal was a series of domestic initiatives, laws, and executive orders President Franklin Roosevelt supported to provide "relief, recovery, and reform" during the Great Depression (1929-1941).

${ }^{51}$ Harold L. Hitchens, "Influences on the Congressional Decision to Pass the Marshall Plan," Western Political Quarterly 21, no. 1 (March 1968), provides an excellent summary on the Congressional debate on Economic Recovery Plan legislation in early 1948. Proponents and opponents of the legislation made a variety of arguments based on politics, economics, and philosophy. Some disapproved of any aid, some thought it too generous, and others thought it inadequate.

${ }^{52}$ Office of the Historian. "Vandenberg, Arthur Hendrick (1884-1951)." Biographical Directory of the U.S. Congress, http://bioguide.congress.gov/scripts/biodisplay.pl?index=V000025 (accessed November 
Vandenberg, who supported the League of Nations and voted for the World Court, was not initially an ardent isolationist, but a visit to Europe in 1935 and service on the Nye Committee investigating the WWI-era munitions industry hardened his views against intervention in the emerging European crisis. He voted for the Neutrality Acts of 1935, 1936, 1937 and 1939 and fought the Roosevelt Administration on every initiative Vandenberg thought might lead to involvement in the emerging European and Asian crises. Drawing on George Washington's Farewell Address, which cautioned against indulging habitual hatred or favor towards any other nations lest the United States become a slave to them, Vandenberg rejected aid for Britain and France because, as the country had learned in 1917, "preliminary aid to one belligerent is calculated to finally precipitate alliance with that same belligerent." On the Senate floor, he said providing aid was an act "short of war" that would lead to war. He abhorred fascism and communism, but would "have America mind her own business," remaining "wholly neutral" until the people, expressing their will through Congress, called for war. ${ }^{53}$

War did come to the United States and with it, Vandenberg gradually turned against isolationism. By early January 1945, when Vandenberg made remarks later known as the "speech heard around the world," his conversion to internationalism was complete. He insisted the country should preserve the relationships made between the Allied Powers during the war, but simultaneously called for candor and an appeal to them, primarily the Soviet Union and the

13, 2013); Francis O. Wilcox interview by Donald Ritchie, Senate Oral History Program (February-March 1984) http://www.senate.gov/artandhistory/history/oral_history/Francis_O_Wilcox.htm (accessed March 9, 2014); Richard C. Bain, Convention Decisions and Voting Records, 2d ed. (Washington, DC: Brookings Institution, 1974).

${ }^{53}$ United States Senate Historian, "Merchants of Death,” U.S. Senate Art \& History, http://www.senate.gov/artandhistory/history/ minute/merchants_of_death.htm (accessed October 19, 2013); Arthur S. Vandenberg, "Peace or War for America," Vital Speeches of the Day 5, no. 12 (April 1, 1939): 354-57. The Nye Committee investigated greed in the munitions industry, the "merchants of death," and the decision to go to war in 1917. The Committee, which included members seeking to nationalize the armaments industry as punishment for leading the nation into WWI, ended without issuing a final report, but directly contributed to legislation that would become the Neutrality Acts of 1935, 1936, 1937 and 1939. 
United Kingdom, to reject the "old ways" that had led to two destructive world wars. Most concerned about the Soviet Union, Vandenberg believed the Soviets could choose, as they seemed to have done, to unilaterally occupy and establish a ring of satellite states as a buffer against aggression or they could work within a multilateral, collective security arrangement. Vandenberg believed the latter paved a road to lasting peace. ${ }^{54}$

The world, he said, "cannot tolerate unilateral privilege in a multilateral peace" and while he had always insisted on American self-reliance, technology had made the world smaller such that no "nation hereafter can immunize itself by its own exclusive action." He threw his support behind the Dumbarton Oaks Conference - an international forum on the future United Nationssaying, "I want maximum cooperation, consistent with legitimate American self-interest, [and] with constitutional process ... to make the basic idea of Dumbarton Oaks [an organization to maintain peace and security] succeed. I want a new dignity and a new authority for international law." Roosevelt, who had been bracing himself for what he expected to be stiff resistance from a vocal critic, seized on the opening offered by Vandenberg and appointed him to the American delegation at the United Nations Conference. ${ }^{55}$

Acceptance of the United Nations, a key postwar initiative of the Roosevelt Administration, did not signal a willingness by Vandenberg to cede what he believed was the Senate's constitutional obligation to remain active in foreign affairs. In this context, he qualified his support for Dumbarton Oaks by insisting it remain "consistent with legitimate American selfinterest [and] with constitutional process. ” It reflects Vandenberg's frustration, shared by others in the Senate and many in the Administration, that American postwar policy seemed adrift,

\footnotetext{
${ }^{54}$ Arthur S. Vandenberg, "The Need for Honest Candor," Vital Speeches of the Day 11, no. 8 (February 1, 1945): 226-30.

${ }^{55}$ Ibid. The Conference met in San Francisco from April 25 to June 26, 1945 to draft an initial charter for the United Nations.
} 
largely because Roosevelt had rarely included others in its development. In fact, almost half of the "speech heard around the world," known primarily for its renouncement of isolationism, is a call for Roosevelt to make a statement of U.S. interests. By implication, Vandenberg assigned to the President the lead on defining interests and policies on which Congress could deliberate. ${ }^{56}$

Cooperation between the White House and the Senate improved significantly when Truman, a former Senator himself, took office. Still, when political scientists and historians refer to the period between 1946 and 1949 as uniquely bipartisan — on foreign policy issues - in character, they largely credit Vandenberg. According to Francis Wilcox, first Chief of Staff for the Foreign Relations Committee (1947-1955), Vandenberg sought equal access to information for committee members regardless of party or position they represented. When he served as Chairman, even if he had the votes to proceed, Vandenberg always "wanted to make sure that all the members were with him, and he took great pride in developing a feeling of unity and a spirit of unanimity" across party lines. Similarly, Vandenberg had several opportunities to criticize the Administration, but invariably, he placed nation before party, believing the debate on national security issues should be rational and politics “ought to stop at the water's edge." Later, Acheson wrote that Vandenberg's first response was "no" to every suggestion, but with time to consider details, his final position would typically improve upon the initial proposal and be nonpartisan. ${ }^{57}$

Wilcox estimated that Vandenberg and Senator Tom Connally (Democrat-Texas), the ranking minority member on the Foreign Relations Committee, spent more than 200 days with

\footnotetext{
${ }^{56}$ Ibid. Emphasis added by the author. Vandenberg had similarly expressed frustration with Roosevelt's unwillingness to engage the Senate on foreign policy in the "War or Peace for America" speech in 1939. In January 1945, Vandenberg was particularly disturbed because while the United States had remained largely silent on several key postwar issues, the Soviet Union and United Kingdom appeared more active. The phrase "constitutional process" would appear again in the Vandenberg Resolution (see Note 7); it was a recurring reference to Vandenberg's insistence on a Senate role in foreign policy.

${ }^{57}$ Almond, xi-xiv; Wilcox, 50 and 55; Acheson, Present at the Creation: My Years in the State Department, 219.
} 
Secretary of State James Byrnes negotiating the U.N. charter and other treaties related to the end of the war. Truman selected Vandenberg as a delegate to two United Nations General Assembly meetings and as an advisor for three meetings of the Council on Foreign Ministers in 1946. In 1947, Vandenberg was one of the Members of Congress invited to the White House to discuss aid to Greece and Turkey. It was Vandenberg, having heard an impassioned pitch from Acheson, who guaranteed support should the President deliver the same message to the American people in a joint session of Congress. After Truman did so, Vandenberg guided the legislative debate for the relief of Greece and Turkey, the Marshall Plan, and the North Atlantic Treaty on behalf of the Administration. Vandenberg is the most prominent official, outside of the Administration, in histories written in this period; clearly, in him, a willing nonpartisan on national security issues, Truman had found someone with whom he could work. ${ }^{58}$

The Economic Recovery Plan (ERP) was not the only major piece of national securityrelated legislation Truman and the Eightieth Congress were able to complete. Aware that the "administrative chaos" common to Roosevelt policymaking was unsustainable as the country assumed greater international responsibilities, Truman, members of his cabinet, and Congress collaborated — with varying degrees of enthusiasm — to enact the National Security Act of 1947. The Act merged the Army, Navy, and new Air Force into a single Department of Defense (DoD),

\footnotetext{
${ }^{58}$ Wilcox, 28; United States Senate Historian, “Arthur Vandenberg: A Featured Biography,” U.S. Senate Art \& History, http://www.senate.gov/artandhistory/history/common/generic/Featured_Bio_ Vandenberg.htm (accessed October 19, 2013); Arthur Vandenberg, "Soviet Pressure, A World Peril," Vital Speeches of the Day 13, no. 13 (April 15, 1947): 391-396; Arthur Vandenberg, "Bipartisan Foreign Policy," Vital Speeches of the Day 15, no. 1 (November 1, 1948): 11-15. The Vandenberg Resolution, passed by the Senate on June 11, 1948 came after everal months of discussions between the Administration, represented by Under Secretary of State Robert A. Lovett, and Vandenberg. It authorized Truman to pursue a collective security agreement consistent with the U.N. Charter, but outside the Security Council. The 82-13 vote in favor was a clear indication of internationalist sentiment in the Senate and empowered the President to negotiate the North Atlantic Treaty. One of the more interesting histories written on the period between delivery of the British notes in late February 1947 through the Marshall address at Harvard University on June 5, 1947 is Fifteen Weeks, by Joseph M. Jones. Written in 1955, he captures the essence of dialogue and debate in this transformative period.
} 
created the Central Intelligence Agency, and established the National Security Council (NSC). Many years later, when former Secretary of State James Baker (Bush, 1989-1992) said, "men like Truman and Acheson were above all . . institution builders," he was referring to international institutions built to secure peace. Given that the U.S. national security apparatus today looks very much as it did in 1948, one could say the same about this domestic accomplishment. ${ }^{59}$

The ability of these organizations to survive, however, belies the controversy that existed at their inception. The final legislation was a compromise that made few happy. Truman, Marshall, and Secretary of the Navy James Forrestal all believed reform necessary, but they disagreed on how. Truman and Marshall wanted to establish a single military department; Forrestal objected, fearing the Army and Air Force would routinely outvote the Navy. Forrestal, on the other hand, wanted to establish a cabinet-level coordinating council; Truman objected, arguing Congress could not tell him how to organize his staff and Marshall objected because he felt State alone was responsible for foreign relations. In the end, to get one, they got both. To show his displeasure, Truman attended the first NSC meeting, primarily to assert his authority to do so, before essentially ignoring it until the Korean War started several years later. ${ }^{60}$

Thus handicapped, the NSC soon had its first major opportunity to fulfill its statutory mission of advising the President on the "integration of domestic, foreign, and military policies

\footnotetext{
${ }^{59}$ Anna Kasten Nelson, "President Truman and the Evolution of the National Security Council." Journal of American History 72, no. 2 (1985): 361; National Security Act of 1947, Public Law 80, § 253, U.S. Statutes at Large 61 (1947): 495-510, codified at U.S. Code 50 (1947), § 401; Baker and DeFrank, 605. Other useful references on the complicated origins and effectiveness of the NSC include: "President Truman and the Evolution of the National Security Council," Richard A. Best, Jr., National Security Council: An Organizational Assessment (New York: Novinka Books, 2001), John Prados, Keeper of the Keys: A History of the National Security Council from Truman to Bush (New York: William Morrow \& Co., 1991), Dale R. Herspring, The Pentagon and the Presidency: Civil Military Relations from FDR to George W. Bush (Lawrence: University Press of Kansas, 2005), and Amy Zegart, Flawed by Design: the Evolution of the CIA, JCS, and NSC (Stanford: Stanford University Press, 2000). The National Security Act of 1947 actually refers to a "National Military Establishment," not a Department of Defense.

${ }^{60}$ Nelson, 360-363; Richard A. Best, Jr., National Security Council: An Organizational Assessment (New York: Novinka Books, 2001), 1-11.
} 
relating to national security so as to enable ... [agencies within] the Government to cooperate more effectively." The coup d'état in Czechoslovakia, the passage of the ERP, and the start of the Berlin crisis led Forrestal, now the first Secretary of Defense, to suggest that it was time the Administration articulated a "comprehensive statement of national policy" that identified risks to U.S. interests and reviewed possible responses. Doing so, he argued, would create unity of effort and was "fundamental to decisions concerning the size of ... [the] national budget." Kennan and the PPS had already begun such a document so the NSC reviewed, debated, and revised their drafts over the course of several months. In November 1948, the NSC approved and the President accepted the final draft titled "U.S. Objectives With Respect to the U.S.S.R. to Counter Soviet Threats to U.S. Security," also known as NSC 20/4. ${ }^{61}$

Reviewing interests, threats, and potential war aims, NSC 20/4 warns that the "immediate purposes and the ultimate objective of the Soviet leaders are inimical to the security of the United States" and would remain so indefinitely. Furthermore, Soviet domination of Eurasia, by aggression or subversion, was "strategically and politically unacceptable." In concluding that political subversion was more likely than war, it proposed initiatives to strengthen the United States economically, politically, and morally while developing also its allies, improving relations with non-aligned countries, and exploiting dissension amongst communists. The country should maintain, it argued, a degree of military readiness to deter the Soviets, embolden allies, and allow for rapid mobilization, when required. Finally, it warned decision makers that, as important as these proposals were, none should permanently damage the economy or American way of life. ${ }^{62}$

\footnotetext{
${ }^{61}$ National Security Act of 1947, Public Law 80, § 253, U.S. Statutes at Large 61 (1947): 495, codified at U.S. Code 50 (1947), § 401; United States Department of State. Foreign Relations of the United States, 1948: General, The United Nations (in Two Parts), 589-592, 599-601, and 662-669.

${ }^{62}$ United States Department of State. Foreign Relations of the United States, 1948: General, The United Nations (in Two Parts), 662-669.
} 
NSC 20/4, the "first comprehensive strategy study to be adapted as national policy," was the culmination of a three-year debate on American-Soviet affairs. It reflected activist internationalism favored by Truman, the political containment proposed by Kennan, and the warnings about overextension put forth by Vandenberg and Lippmann. It benefited from an unusual set of circumstances surrounding capable men—sometimes wise, sometimes foolish, and typically prudent according to Melvin Leffler-uniquely able to work through new challenges and new organizations. It is for others to debate the merits of the policy adopted and institutions created, but there can be little doubt that what these men built laid the cornerstone of American national security affairs for forty years. ${ }^{63}$

${ }^{63}$ Melvyn. Leffler, A Preponderance of Power: National Security, the Truman Administration, and the Cold War (Stanford, CA: Stanford University Press, 1992), 264-265 and 495-511; Almond, xiv. None of this is to suggest that U.S. foreign policy perfectly mirrored what these men thought or that it has been unchanging. Every president who followed Truman modified or contributed to U.S. foreign policy in some way, none strictly adhered to any one line of thought. Kennan, for example, was vigorous in his assertion that he was misunderstood and that Truman and his successors distorted his message. See his Memoirs, page 320-324, and "George Kennan: A Life in the Foreign Service," by Wilson Miscamble. 
New realities are changing the entire world ... differences and contradictions inherited from the past are ... being displaced.

- Mikhail Gorbachev, General Secretary, Soviet Union, December 7, $1988^{64}$

\section{POST COLD WAR}

Columnist George Will referred to 1989 as the "most startling, interesting, promising, and consequential year ever." While hyperbole, dramatic events around the world - the withdrawal of Soviet forces from Afghanistan, violent demonstrations in China, multiparty elections in Poland and Hungary, the collapse of communist regimes in Czechoslovakia and Romania, and the fall of Berlin Wall—created a great deal of hope and foreshadowed the end of the Cold War. Two years later, the Soviet Union disintegrated, President George H.W. Bush declared the Cold War over, and the United States found itself, forty years after introducing the Truman Doctrine and containment, a victor with no clear vision of the peace. ${ }^{65}$

In the decade following 1991, the United States was without peer, preeminent beyond comparison, "in terms of power and influence, to anything known in modern history." It used this influence to lead a coalition against Iraqi aggression, to enable the reunification of Germany, to expand NATO, to conduct humanitarian, peace enforcement, and peacekeeping missions in Somalia, Bosnia, Haiti, and Kosovo, and to strengthen trade relationships through a variety of regional and global agreements. Repeatedly, it was the "indispensable nation," without whose leadership few other countries acted. There seemed, however, to be no unifying purpose, like that established by Truman, because there was no agreed upon vision of the future, its threats and opportunities, and potential policies and strategies with which to proceed. ${ }^{66}$

\footnotetext{
${ }^{64}$ Seyom Brown, The Faces of Power: U.S. Foreign Policy from Truman to Clinton (New York: Columbia University Press, 1994), 504.

${ }^{65}$ George F. Will, “Europe's Second Reformation,” Newsweek 114, no. 21 (November 1989): 90.

${ }^{66}$ G. John Ikenberry, After Victory: Institutions, Strategic Restraint, and the Rebuilding of Order After Major Wars (Princeton, NJ: Princeton University Press, 2001), 270 and 277-281; Warren Christopher, "International Peace," Vital Speeches of the Day 59, no. 13 (April 15, 1993). Quote by French Foreign
} 
That economic considerations were paramount was clear. The cost of waging forty-five years of cold war had contributed to the collapse of the Soviet Union and threatened the economic security of the United States. From 1948-1973, U.S. defense spending was never less than thirty percent of federal outlays - it was well over half during the Korean and Vietnam War yearsbefore dropping to the $25-29 \%$ range from 1974-1989. The federal debt, stable for most of the Cold War, grew dramatically during the defense build-up led by the Reagan Administration (1981-1989). Debt is a function of revenues and spending on a variety of programs, not just defense, but it is difficult to deny the impact $\$ 34$ million per hour spent on defense had in $1988 .{ }^{67}$

The United States was in a class of its own, but to outlast the Soviets, it had mortgaged its future. Soviet Foreign Minister Eduard Shevardnadze and Ambassador Thomas Watson, in a joint press conference acknowledged that, "by taking the brunt of the arms race on ourselves, the U.S. and U.S.S.R. are beginning to lose the competition in other areas." Other nations, "freed from this burden, surged ahead of us ... [in the end] both of us lost the arms race ... the victors thus become losers." To what then would the United States be willing and able to commit? What were its national security interests? How would it handle its role as sole superpower? ${ }^{68}$

Minister Hubert Vedrine in 1999. In 1996, the U.S. spent $\$ 195$ billion more on defense than Russia, placing it comfortably in first place, and it was second on the "correlates of war" index behind China. For more on the "correlates of war," see J.D. Singer and Paul Diehl, eds. Measuring Correlates of War. The U.S. has led the world in gross domestic product since before 1910. Between 1985 and 1996, it expanded, in real dollars, its lead over every other leading industrialized nation. German unification was not a foregone conclusion as the Soviets, British, and French objected; U.S. support and leadership in the negotiations mollified their concerns. Clinton and members of his Administration used the phrase "indispensable nation" to describe America's obligation to lead because others do not.

${ }^{67}$ Office of Management and Budget, Historical Tables: Budget of the United States Government, Fiscal Year 2009 (Washington, DC: Government Printing Office, 2008), Table 3.1, 47-52.

${ }^{68}$ Thomas G. Paterson, "Superpower Decline and Hegemonic Survival," in Major Problems in American Foreign Relations, edited by Thomas G. Paterson \& Dennis Merrill (Lexington, MA: D.C. Heath and Company, 1995), 727-728. 
Most writers immediately recognized the "new world order" was more complex and potentially less stable than had been the old. In late 1989, Deputy Secretary of State Lawrence Eagleburger said it would be more difficult in the future "to tell the good guys from the bad guys." Less than a year later, international relations theorist John Mearsheimer penned an article, "Why We Will Soon Miss the Cold War," in which he argued the United States might not miss the violence of the Cold War, but would miss the order it gave to the "anarchy of international relations." Whether the future would prove his arguments valid or not, the term "anarchy" seemed an apt description of the breadth of problems facing policy makers at this time. ${ }^{69}$

Late in the twentieth century, the world was full of contradictions. It was both "smaller," its states increasingly interdependent, yet more fragmented with modernization, unevenly shared across wealthy and poor nations, clashing with traditionalism. As the accomplishments listed earlier show, cooperation between major states was possible, but without a looming threat, former friends and allies were more willing to define their interests independently of each other and to focus on concerns long ignored. The list was lengthy. A March 1990 poll of Americans listed drugs, chemical and nuclear weapons proliferation, violent crime, increasing costs of health care, the deficit and economic competition, terrorism, climate change and nuclear power plant accidents as greater concerns than conflict in the Middle East, Central America, or with the Soviets. As a start point for prioritization, the poll's results are both everything and nothing, inclusive and yet so expansive traditional understandings of security no longer applied..$^{70}$

\footnotetext{
${ }^{69}$ John Prados, Keeper of the Keys: A History of the National Security Council from Truman to Bush (New York: William Morrow \& Co., 1991), 557; John Mearsheimer, "Why We Will Soon Miss the Cold War," The Atlantic Monthly 266, no. 2 (August 1990): 35-50.

${ }^{70}$ John P. Lovell, The Challenge of American Foreign Policy: Purpose and Adaption (New York: Macmillan Publishing Company, 1985), 302-316; Gregory F. Treveton and Barbara A. Bicksler, "Conclusion: Getting from Here to Where?" in Rethinking America's Security: Beyond Cold War to the New World Order, edited by Allison Graham and Gregory F. Treveton, 407-433 (New York: W.W. Norton \& Company, 1992), 420. There were occasional rough patches, but U.S. relations with its European and
} 
There was no shortage of attempts to redefine security, though typically by policy experts, academics, and theorists and less so from government officials. The Center for Strategic and International Studies (CSIS), Council on Foreign Relations (CFR) and others published collections of essays reflecting on the past, making predictions for the future, and proffering recommendations on how the United States should chart its path in the new normal. New voices—-such as Francis Fukuyama, John Mearsheimer, Robert D. Kaplan, and Paul Kennedy— joined the familiar - Henry Kissinger, Zbigniew Brzezinski, Samuel Huntington, and Alvin Toffler-but noticeably absent was a voice from within the government. No figure emerged to capture the imagination for a new era in the way George Kennan had four decades earlier. Before turning to the government's effort to chart a course, a review of several perspectives illustrate the breadth of ideas swirling amongst academics, journalists, and prominent think tanks. ${ }^{71}$

\section{Major Ideas of the Post-Cold War Period}

In 1989, Francis Fukuyama, an academic and political scientist with service in the Rand Corporation and on the Policy Planning Staff at the State Department, wrote that the growing success of liberal democracies over communism signaled the "End of History." Inspired by

Asian allies were never in serious danger during the Cold War. By 1990, however, the lingering effects of Vietnam, tension over the deployment of nuclear weapons into Europe, maturation of the European Union, and optimism about Soviet reforms all provided Europeans confidence and impetus to weaken gradually their commitment to the U.S. See Thomas G. Paterson, "Superpower Decline and Hegemonic Survival."

${ }^{71}$ Rethinking America's Security was a collaborative effort between the CFR and The American Assembly, a non-partisan think tank started by Dwight D. Eisenhower and affiliated with Columbia University. In The Rise and Fall of the Great Powers, Kennedy wrote that the relative distribution of economic and military strength shape relationships between great powers and predicted the U.S. was in a period of decline. He also wrote Preparing for the Twenty-First Century (1994) on global population growth and resource scarcity. Kissinger and Brzezinski, veterans of the Nixon, Ford and Carter Administrations, were mentors to many of the policymakers of the Bush and Clinton Administrations. See David Rothkopf, Running the World. These veterans wrote on the changing nature of international affairs and what the U.S. should do about it. Kissinger was a balance of power realist and Brzezinski stressed multilateralism grounded in international institutions like the U.N. See Diplomacy (1994), Does America Need a Foreign Policy (2001), Out of Control (1993), Grand Chessboard (1997) as well as their journal articles. Alvin Toffler, a futurist, wrote Future Shock (1970) and The Third Wave (1980) to describe the impact of technology, modernization, and globalization on society. 
glasnost, perestroika and reform-minded demonstrations in Eastern Europe and China, Fukuyama observed that "unmistakable changes in the ... world's largest communist countries" coupled with the rapid expansion of Western culture signaled the end of man's ideological evolution. History, he wrote, ended with the "universalization of Western liberal democracy ... [as] the final form of human government." He acknowledged that issues of religion and nationalism might remain unresolvable and democracies still had their injustices, but he envisioned conflict isolated to states who had not reached the end of history, wars of nationalism, and unique ethnic struggles. Conflict between post-historical states bound by a common form of governance, culture, and economics would cease to exist. ${ }^{72}$

Fukuyama was not completely optimistic. In his closing, he almost lamented the end of history, suggesting the challenges of a great ideological struggle had inspired men to greatness and at the end of history, the boredom of "economic calculation ... endless solving of technical problems, environmental concerns, and the satisfaction of sophisticated consumer demands" could destroy art and philosophy. Perhaps in the ideal he would be correct, but within a decade the principles of democratic peace theory, which his writing essentially reflected, became justification for nation-building efforts in the Balkans and the Middle East. As of this writing, Fukuyama's prediction that liberal democracies could avoid violent conflict between themselves has proven accurate, but indirectly, it inspired them to export their values in the hope they could bring other countries to the end of history. The boredom he predicted has not materialized. ${ }^{73}$

\footnotetext{
${ }^{72}$ Francis Fukuyama, “The End of History,” The National Interest 16 (Summer 1989): 3-18. Fukuyama wrote before the fall of most communist regimes in Eastern Europe and several years before the Soviet Union collapsed, but it was evident - liberalization in Poland, glasnost and perestroika in the Soviet Union, demonstrations in China - that something was taking place. What the end of that "something" would look like was the question. Glasnost and perestroika, openness in governance and restructuring of institutions and markets, are Russian terms for the major domestic initiatives instituted by Gorbachev.

${ }^{73} \mathrm{Ibid}, 18$. The idea of perpetual peace between post-historical states or liberal democracies did not originate with Fukuyama. The German philosopher Immanuel Kant (1724-1804) made common a term first
} 
John Mearsheimer, an international relations theorist and political science professor at the University of Chicago, offered a different perspective than did Fukuyama. Beginning in 1990, Mearsheimer published a series of articles and a book that asserted his theory of "offensive realism," which argued that states value their security above all else. Mearsheimer rejected those who said competition between states was outdated and economic interdependence led to peace. In his view, shared forms of government, cultures, and economies were less important than each state's irresistible drive for survival and therefore each sought greater security, typically by gaining and exerting influence at the expense of others. The root cause of conflict between great powers, he argued, lay in the distribution — or perceived distribution—of power and influence; "small gaps foster peace; large gaps promote war." The United States would miss the Cold War, because bipolarity between two relatively equal, nuclear-equipped superpowers who reduced the influence of hyper-nationalism and maintained a degree of order had created a "long peace" whose end might be found in the collapse of the Soviet Union. ${ }^{74}$

Mearsheimer offered the following suggestions to U.S. policymakers. First, the United States must prevent great power wars by balancing potential aggressors quickly and forcefully

used by French author Charles-Irénée Castel de Saint-Pierre (1658-1743) when he published his essay "Perpetual Peace: A Philosophical Sketch" in 1795. The body of thought started with these two and continued to its contemporary adherents asserts that states that meet certain criteria including republicanism, transparent foreign relations, open markets and borders, and membership in international bodies are more peaceful not only with each other, but with states not meeting those criteria. The 2002 and 2006 National Security Strategies published by the George W. Bush Administration (2001-2009) suggest this line of thinking explains some of its foreign policy. Furthermore, Paul Wolfowitz was very close to Fukuyama until the latter withdrew his support for the wars in Afghanistan and Iraq over concerns the Administration had failed to reconcile realism (i.e., what it could accomplish) with idealism (i.e., democratic peace theory). See Andrew Bast's review of Fukuyama's book Origins of Political Order at http://www.newsweek.com/francis-fukuyama-book-origins-political-order-66555.

${ }^{74}$ John J. Mearsheimer, "Back to the Future: Instability in Europe After the Cold War," International Security 15, no. 1 (Summer 1990); John J. Mearsheimer, "Disorder Restored," in Rethinking America's Security, edited by Graham Allison, \& Gregory F. Treverton, 213-237 (New York: W.W. Norton \& Co., 1992); Mearsheimer, "Why We Will Soon Miss the Cold War." Mearsheimer published The Tragedy of Great Power Politics, a detailed explanation of offensive realism theory in 2001. Though it was not part of the debate in the 1990s, it is a useful summary of his thoughts. 
even if this meant enabling the proliferation of nuclear weapons to friendly states. Second, it should avoid intervention in the undeveloped world, a region he saw as posing no threat to U.S. vital interests and which offer its enemies no advantage. Intervention in these regions, he argued, prolonged rather than shortened conflict, caused unnecessary casualties and damage to U.S. prestige, and solved nothing. Third, the United States must continue to tamp down hypernationalism at home and abroad. Finally, the United States and its closest allies, the British, must counter aggression actively and effectively where their shared interests are at risk. ${ }^{75}$

Perhaps the most widely discussed and controversial writer at the end of the Cold War was Samuel Huntington, an academic, author, and briefly, member of the National Security Council (NSC) staff during the Carter Administration (1977-78). In 1991, Huntington wrote "Third Wave" to describe the phenomena of democratization seen in more than sixty countries in the previous seventeen years. Some rejected his premise because many of these countries were democratic only superficially; others embraced his observations. They agreed that a lack of legitimacy amongst authoritarian states and growing emphasis by the United States and its allies to tie economic and political support to human rights had advanced democracy. Huntington warned that imbalances in many countries, particularly in Africa, may retard or even set back its spread, but was cautiously optimistic that with the right mix of economic development, political leadership, and patience, democracy would be the system of choice globally. ${ }^{76}$

${ }^{75}$ Mearsheimer, "Why We Will Soon Miss the Cold War"; Mearsheimer, "Disorder Restored." The U.S. continues to wrestle with is relationship with China, uncertain whether it is a threat to be balanced or a friendly competitor with whom it can coexist. It has repeatedly found itself enmeshed in the Third World and had almost no success tamping down nationalist-driven self-determination efforts in multiple regions. It remains to be seen whether American and British efforts to counter aggression in the Middle East and on the Korean Peninsula will succeed.

${ }^{76}$ Samuel Huntington, “Democracy's Third Wave," Journal of Democracy 2, no. 2 (Spring 1991): 12-34. 
Two years later, Huntington seemed to turn on this optimism. In "Clash of Civilizations," the article and book for which Huntington is probably best known to contemporaries, Huntington wrote that "world politics is entering a new phase, and intellectuals have not hesitated to proliferate visions of what it will be - the end of history [i.e., Fukuyama], the return of traditional rivalries [i.e., Mearsheimer] ... decline of the nation state.” All, he wrote, were wrong. History had seen wars between princes, peoples, and then ideologies; the next phase, he argued, was wars along the physical and conceptual fault lines of the world's seven or eight major cultural groups. The differences between them, he wrote, were real, basic, and absolute. Where the ideological conflict between capitalism and communism, shadowed by the threat of nuclear holocaust, had bound disparate cultures together, the end of the Cold War and the absence of ideological hegemons who could enforce order allowed cultural differences to emerge as predominant sources of conflict. Huntington wrote, "the Velvet Curtain of culture has replaced the Iron Curtain of ideology." 77

In the short term, Huntington wrote, states in the Western group - the United States, Canada, Western Europe, Australia, and New Zealand—should find accommodation and cooperation with other cultures to which they can most closely relate, Latin America and Eastern Europe. At the same time, they must take action to strengthen themselves, prevent disruption or conflict within their group, and limit the expansion and influence of civilizations - Confucian and Muslim — with whom they have very little or nothing in common. Over the long term, they needed to retain their economic and military advantages, but must also develop a deeper understanding of the basic assumptions under which other cultures operate. Coexistence in a

\footnotetext{
${ }^{77}$ Samuel Huntington, "Clash of Civilizations," Foreign Affairs 72, no. 3 (Summer 1993): 22-23, 25-28, and 31. Huntington built his reputation with The Soldier and the State (1957) and Political Order in Changing Societies (1968).
} 
world divided between "us" and "them" was prone to conflict that only strength and diplomacy could diffuse. ${ }^{78}$

Finally, in 1994, Robert D. Kaplan, a journalist for The Atlantic Monthly, wrote an equally pessimistic article. Insisting Western policy makers had overlooked the new " $\mathrm{X}$ " article, Kaplan highlighted the work of a Canadian academic, Thomas Fraser Homer-Dixon, who combined conflict and environmental studies to paint a dim view of the future. Homer-Dixon imagined an air-conditioned limousine, its insides containing post-industrial, secure, and comfortable North America, Europe, and a few other isolated regions, travelling on potholed streets through a filthy city where the rest of the world resided. The "rest," roughly $95 \%$ of humanity, lacked fresh water and clean air, endured a variety of social ills, and suffered under corrupt, inefficient, and unresponsive governments. Outside the limousine, where life is "poor, nasty, brutish, and short," democracy was absent or at risk and totalitarianism, fascism, and warlordism were far more likely. Leaders of post-industrial states had ignored their physical surroundings for too long, Homer-Dixon wrote, and "nature is coming back with a vengeance." 79 In this environment, Kaplan wrote, many of the insecure see war and violence both as a means to a better end and an end itself. Furthermore, Kaplan, citing renowned military writer

\footnotetext{
${ }^{78}$ Ibid, 48-49.
}

${ }^{79}$ Robert D. Kaplan, “The Coming Anarchy,” The Atlantic Monthly 273, no. 2 (1994): 44-76; Thomas F. Homer-Dixon, "On the Threshold: Environmental Changes as Causes of Acute Conflict," International Security 16, no. 2 (Fall 1991): 76-116. Thomas Fraser Homer-Dixon was, Chair, Peace and Conflict Studies, University of Toronto and he wrote "On the Threshold: Environmental Changes as Causes of Acute Conflict" in 1991. Neither Kaplan nor Homer-Dixon would embrace the label of environmentalist, but both argued there were environmental and societal issues that demanded attention sooner rather than later. In his conclusion, Homer-Dixon wrote: "We must in particular look for intervening variablesincluding institutions, technologies, and market mechanisms - that humankind might influence in order to change the course of environmental-social systems. We may learn that there are real opportunities for intervention; hardship and strife are not preordained. But it seems likely that, as environmental degradation proceeds, the size of the potential social disruption will increase, while our capacity to intervene to prevent this disruption decreases. It is therefore not a reasonable policy response to assume we can intervene at a late stage, when the crisis is upon us. Developing countries, in concert with the North, should act now to address the forces behind environmental degradation." 
Martin Van Creveld, argued conflict would become increasingly fanaticized and primitive with modernization and globalization absent in some places and exploited for criminal and war-like purposes in others. State power, such as it is, will fade as families and communities seek improvement through private armies and gangs. Kaplan, whom the Clinton Administration took seriously, saw growing instability, greater transnational crime and violence, and dangers to the United States not just in the chaos these bring themselves, but in its own social fabric and in its inability to manage special interests demanding action in each crisis. The United States ignored, he wrote, these places and sources of conflict, at its own peril. The question Kaplan prompted was, "What can and should we do when violence breaks out in countries far from our borders?" 80

The degree to which these men, individually or collectively, influenced dialogues within the government cannot be clear. While the available memoir literature rarely singles out individual authors from this period, the above figures give a sense of the discourse in the early 1990s. Still, it is difficult to believe members of the Bush and Clinton national security teams were ignorant of the ongoing conversations taking place between these and other prominent academics, think tanks, and journalists. Clinton was himself an avid reader and his staff credits another of Kaplan's works, Balkan Ghost, for justifying his reluctance to intervene in Bosnia. Ironically, in that case Clinton drew a conclusion to which the author objected. Regardless, the

\footnotetext{
${ }^{80}$ Kaplan, The Coming Anarchy, 1994, 72-73; David Lipsky, “Appropriating the Globe," The New York Times. November 27, 2005. http://www.nytimes.com/2005/11/27/books/review/27lipsky.html?ex= 1178078400\&en=2931d7 d8ea0d5e62\&ei=5070\&_r=0 (accessed February 2, 2014); Robert D. Kaplan, The Coming Anarchy (New York: Random House, 2000), xv; Geoffrey Dabelko, "The Environmental Factor," The Wilson Quarterly 23, no. 4 (Autumn 1999): 14-19. According to Dabelko, Gore directed the Central Intelligence Agency (CIA) "to oversee a systematic investigation of the causes of 'state failure' it [The Coming Anarchy] described." Samuel R. Berger, then deputy national security adviser, scheduled a hurried meeting to address the issues Kaplan had raised. Homer-Dixon became a regular on flights between Washington and Toronto." See next paragraph for the role another Kaplan book played in Clinton's decisions on Bosnia.
} 
real test of the new world order was not what theorists postulated, but how politicians, diplomats and legislators acted. ${ }^{81}$

\section{National Security during the George H.W. Bush Administration}

George H.W. Bush, the last member of the "Greatest Generation" to become President, had been a combat pilot, business executive, politician, and diplomat. He served in the U.S. House of Representatives (1967-1971), as an Ambassador, first to the United Nations (1971-73), then to the People's Republic of China (1974-75), and as Director of the Central Intelligence Agency (CIA, 1976). Failing to gain the Republican nomination for President in 1980, he joined the Reagan ticket and became Vice President (1981-89). With two decades of government service, the experience in national security affairs he brought to the White House outclassed all other post-WWII presidents save Dwight Eisenhower and Richard Nixon.

When he announced his campaign for the presidency in 1987, George H.W. Bush, then the Vice President, told the American people, "I am a practical man. I like what's real. I'm not much for the airy and abstract: I like what works ... I do not yearn to lead a crusade.” Bush never shied from viewing his pragmatism as a strength—a book co-written with Brent Scowcroft makes much of their "prudence"-but in the rapid pace of events then shaping the world, his critics saw prudence not as a virtue, but untimely vice. Despite carrying impressive credentials, particularly

\footnotetext{
${ }^{81}$ Michael T. Kaufman, “The Dangers of Letting a President Read,” The New York Times, May 22, 1999 http://www.nytimes.com/1999/05/22/books/the-dangers-of-letting-a-president-read.html (accessed February 3, 2014); Christopher, In the Stream of History: Shaping Foreign Policy for a New Era, 347. According to Les Aspin and Warren Christopher, Clinton came away from Balkan Ghosts convinced the legacy of violence in Bosnia meant U.S. intervention would lead to an unsolvable quagmire. Interestingly, Baker, Christopher, Talbott, etc. memoirs mention George Kennan and other Truman-era officials more than they do thinkers, legislators, etc. of their own time.
} 
in foreign relations, the traits he emphasized in October 1987 haunted the Bush Administration, provided fuel for critics, and became his legacy. ${ }^{82}$

Bush understood the world was evolving, largely because of reforms within the Soviet Union, but was initially skeptical of Soviet intentions. Ironically, Bush, who had recoiled at Reagan's anti-communist rhetoric several years earlier, entered office with less faith in Mikhail Gorbachev than Reagan had come to possess. When Bush ordered a review of national security policies, he told his staff to seek boldness, yet urged caution. Expressing confidence in the "broad elements of our current strategy," he sought new ideas that considered Soviet reforms, but was not ready for a wholly "new strategy." He remained mindful that previous attempts at reform within the Soviet bloc had ended in brutal crackdowns (i.e., East Germany, 1953; Hungary, 1956; Czechoslovakia, 1968; and Poland, 1981) so wished to proceed with caution. He pondered difficult questions. Were glasnost and perestroika sincere initiatives or was Gorbachev merely more cunning than were his predecessors? Could Gorbachev control Soviet hardliners and enact sustainable reforms? Without answers, it was "foolish to assume that all dangers have disappeared" and important for the United States to remain patient and preserve its strength. ${ }^{83}$ Initially eschewing dynamic action, Bush observed and assessed, at times appearing to prefer the stability of the status quo to the uncertainty of rapid and dynamic change. He made continued commitments to defense spending, albeit not at the levels seen in the early Reagan Administration, and he resisted calls for economic aid to Eastern Europe and the Soviet Union. He offered some ideas on disarmament, but constantly seemed a step behind proposals offered by

\footnotetext{
${ }^{82}$ Peter W. Rodman, Presidential Command: Power, Leadership and the Making of Foreign Policy from Richard Nixon to George W. Bush (New York: Alfred A. Knopf, 2009), 202.

${ }^{83}$ George H.W. Bush and Brent Scowcroft, A World Transformed (New York: Alfred A. Knopf, 1998), 39-43; The White House, National Security Review 12, by George H.W. Bush (Washington, DC, 1989); George H.W. Bush, “Commencement Address” (Texas A\&M University, College Station, TX, Mat 12, 1989), http://millercenter.org/president/speeches/detail/3421 (accessed March 9, 2014);
} 
Gorbachev. Disappointed moderates in Congress, American diplomats and allies in Europe saw opportunities that might slip away. These groups sought statements, policies, and actions on aid, disarmament, and other issues that would signal American support of Gorbachev and Eastern European reformers. Several months into Bush's policy review, Margaret Thatcher told Secretary of State James Baker, III that she was getting impatient for Bush to establish a sense of direction and she was sure Gorbachev was as well. In time, even Bush recognized he was "getting beat up day after day for having no vision" as Gorbachev, "in cowboy fashion," offered one new proposal after another, each more dramatic than its predecessors. ${ }^{84}$

By the end of his first year in office, two events-Soviet acceptance of U.S. terms on several disarmament initiatives and the peaceful fall of the Berlin Wall—convinced Bush the Soviets were in trouble and Gorbachev must "be serious - more serious than I realized." While committed to a policy that was "very deliberate: encouraging, guiding, and managing change without provoking backlash and crackdown ... [that created] no losers, only winners," he became more assertive. He sought advantage on a variety of issues - disarmament, self-determination, political and economic reform, unification of Germany_-but avoided actions and comments that might embarrass the Soviets or appear exploitative as their sphere dissolved. As an example,

${ }^{84}$ Norman A. Graebner, Richard D. Burns, and Joseph M. Siracusa, American and the Cold War, 1941-1991 (Praeger Security International, 2010), http://psi.praeger.com/doc.aspx?d=/books/gpg/A2979C/ A2979C-1379.xml (accessed December 30, 2013); Brown, 513-515; Bush, "Commencement Address." Ambassador John Matlock, who witnessed Soviet reforms in person in Moscow, titled a chapter in his memoirs on this period, "Washington Fumbles" and Anatoly Chernyaev, a Gorbachev advisor, referred to 1989 as the "lost year." Perhaps, Thatcher thought Bush would be more prepared to articulate what he hoped to achieve and how because he had been Vice President for eight years immediately prior. Bush, however, was not merely a continuation of Reagan and the world he inherited was not the same as the one in which most of his Vice Presidency had taken place. Notably, thirty-nine months elapsed between the end of WWII (August 1945) and adoption of NSC 20/4 (November 1948). No one had the patience to wait that long for Bush to publish a strategy to guide the United States beyond the Cold War. 
Bush's position on the independence of former Soviet Republics reflected his desire for peaceful change, though at a pace acceptable to and respectful of Soviet sensitivities. ${ }^{85}$

As confidence in the irreversibility of change grew, Bush embraced the opportunity to establish a "new world order" in which U.S. leadership was indispensable, but international organizations played deciding roles. Bush relied heavily on the United Nations (U.N.), finally "playing the role dreamed of by its founders ... orchestrating and sanctioning collective action," to organize the coalition which reversed the Iraqi occupation of Kuwait. When the Soviets, British, French and smaller European states opposed German reunification, fearful a unified Germany would become aggressive, Bush championed that country's continued membership in NATO, an organization led by the United States, as a check on potential German ambition. On the economic front, Bush sought new trade agreements, particularly in South America, and ensured the "Group of Seven" (G-7), a recurring meeting of the seven largest economies, extended an invitation to the Soviets to participate as an associate member. In tying the world together, Bush sought to institutionalize stability just as Truman had done before. ${ }^{86}$

\footnotetext{
${ }^{85}$ Brown, 512; Michael R. Beschloss and Strobe Talbott, At the Highest Levels: The Inside Story of the End of the Cold War (New York: Little Brown \& Co., 1993), 132; George H.W. Bush, "The President's News Conference," Public Papers - 1989 - December, http://bushlibrary.tamu.edu/research/ public_papers.php?id=1298\&year=1989\&month=12 (accessed March 9, 2014); James A. Baker III and Thomas M. DeFrank, The Politics of Diplomacy: Revolution, War and Peace (New York: Putnam's Sons, 1995), 203 and 238-245; Bush and Scowcroft, 215, 226, and 228. Lithuania serves as a useful illustration. In January 1990, soon after the Lithuanian government asserted its independence, Baker met with Shevardnadze and privately suggested the Soviets allow the Lithuanians to hold a referendum on independence. As the situation worsened, Bush kept most of his comments with Gorbachev private. Bush clearly supported Lithuanian independence - the U.S. had for forty-five years - but cautioned the Lithuanians to be patient lest they experience what had befallen the Hungarians in 1956. In 1991, tired of Soviet heavy handiness, Lithuania would be the first former Soviet Republic the U.S. recognized before the Soviet Union had done so. In August 1991, many criticized Bush for suggesting to the Ukrainians, who were preparing to vote on independence, that they avoid "suicidal nationalism" and seek a federation with the Russians. William Safire (International Herald Tribune, December 7, 2004) called it the "Chicken Kiev Speech," the Boston Globe (August 3, 1991) said it was "Bush League [in Kiev]." This speech haunted Bush through his reelection campaign the following year.
}

${ }^{86}$ The White House, The National Security Strategy of the United States, by George H.W. Bush (Washington, DC, 1990); The White House, The National Security Strategy of the United States, by George 
Comparing Reagan and Bush National Security Strategies (NSS) highlights a change in the way Bush viewed national security. Increasingly, subsequent NSSs dedicated space to broader issues such as global economic imbalances, competitiveness and debt, weapon proliferation, illicit drugs, energy. Doing so did not mean Bush, who had made clear he was not looking for crusades to wage, was anxious for the United States to get involved everywhere, every time. As crises in Bosnia, Somalia, and Haiti emerged, he reverted to his preference for "wait and see," carefully measuring the cost and benefits of intervention against American interests. He balanced principled beliefs in the righteousness of democracy with constrained expectations of what the country could and should do to affect change. To Bush the pragmatist and realist, relations between states, not events within states, mattered. This was a distinction between Bush, his successor, William (Bill) Clinton, and others expecting the United States to use its newfound status as the sole superpower to improve the human condition worldwide. ${ }^{87}$

\section{National Security during the William (Bill) J. Clinton Administration}

Unlike his predecessor, Clinton entered the Oval Office in 1993 without practical experience in the federal government or in foreign affairs. Furthermore, born after WWII, his election marked a generational change in the leadership of the United States. A product of the 1960s, memories of the Cuban Missile Crisis, erection of the Berlin Wall, the Soviet crackdown in Czechoslovakia, and the Vietnam War informed Clinton's view of the world while President

H.W. Bush (Washington, DC, 1991); Ikenberry, 232-233; Baker and DeFrank, 605-606. The Bush Administration supported efforts to "institutionalize" the new world order through cooperative agreements and forums, but opposed attempts to establish international control, governance, or regulations. This is most evident in the Administration's rejection of the Conventions on Biodiversity and Climate Change. See Brown, Faces of Power, 574-6. For the role of institutionalization, see Ikenberry, After Victory.

${ }^{87}$ The White House, The National Security Strategy of the United States, by Ronald Reagan (Washington, DC, 1988); Bush, The National Security Strategy of the United States, 1990; Bush, The National Security Strategy of the United States, 1991; The White House, The National Security Strategy of the United States, by George H.W. Bush (Washington, DC, 1993); Brown, 556-557 and 563-565; Richard N. Haass, "Fatal Distraction: Bill Clinton's Foreign Policy," Foreign Policy 108 (1997): 112-123. 
John F. Kennedy and Martin Luther King, Jr. inspired him to pursue public service. In college, he interned for Senator J. William Fulbright, a multi-lateralist and the longest serving Chairman of the Senate Foreign Relations Committee; Fulbright became a lifelong mentor to Clinton. Clinton, who opposed the Vietnam War, never served in the military, instead attending Oxford as a Rhodes Scholar and ultimately graduating from Yale Law School. Subsequently, he returned to Arkansas, taught law briefly and won his first elections, the Attorney Generalship in 1976 and Governorship in 1978. He remained Governor for all but two of the next fourteen years. ${ }^{88}$

Bush was enormously popular following the defeat of Iraq in early 1991, but by the time of the general election in 1992, his popularity had plummeted. The American people, satisfied they had won the Cold War, found themselves enmeshed in recession and deeply unhappy with a President who had promised "no new taxes," ultimately violated that pledge, and then seemed unable to resolve a lingering economic recession. Under the simple slogan—“"The Economy, Stupid"-Clinton largely kept the election focused on domestic issues, avoiding discussion on foreign affairs except to occasionally criticize Bush for not acting to quickly enough to assist the Russians in their transition, for failing to arrest ethnic violence in Bosnia and for ignoring the humanitarian crisis in Somalia. In a three-way race, Clinton won without gaining a majority. ${ }^{89}$

\footnotetext{
${ }^{88}$ William J. Clinton, My Life (New York: Random House, 2004); Strobe Talbott, The Russia Hand (New York: Random House, 2002), 5, 11, and 13. Biographical data from My Life, a memoir written by Clinton. Until 1986, Arkansas held gubernatorial elections biennially. Clinton won in 1978, lost in 1980, then won again in 1982, 1984, 1986, and 1990. Fulbright was Chair for sixteen years, a record standing today. While Clinton lacked real world experience in foreign affairs, he was highly educated and a significant portion of his education focused on international affairs and took place in Europe. He had also travelled extensively as a student and sought foreign markets for Arkansan goods while Governor. In 1968, while at Oxford, he had even written a paper on "Political Pluralism" that predicted democracy was in the Soviet Union's future. See The Russian Hand, 5 and 13.

${ }^{89}$ Michael Kelly, "The Democrats - Clinton and Bush Compete to Be Champion of Change; Democrat Fights Perceptions of Bush Gain," The New York Times, October 31, 1992, http://www.nytimes. com/1992/10/31/us/1992-campaign-democrats-clinton-bush-compete-be-champion-change-democratfights.html (accessed January 29, 2014); Talbott, The Russia Hand, 23-25. Ross Perot, running as an independent candidate, was the third major candidate for President in 1992. He collected 19 million votes, a
} 
Following his election, Clinton was determined to focus on the domestic agenda he believed his election validated and desperately sought to avoid international issues. In a transition meeting with the House Foreign Affairs Committee, Clinton told Lee Hamilton, the Chair, "I just went through the whole campaign and no one talked about foreign policy at all, except for a few members of the press." If the American people were not interested, neither was Clinton. According to one advisor, previous presidents, particularly those from the Cold War era, might spend $60-70 \%$ of their time on international matters, Clinton intended to spend less than a quarter. He chose an unassuming Secretary of State, Warren Christopher, nominated him late in the transition — after he had nominated his domestic advisors — and charged him with keeping international issues on the back burner. He even told Stobe Talbott, a close friend and advisor, no formal approach to foreign relations was necessary, as he would follow Roosevelt and Truman who just "made it up as they went along." Wrong in his understanding of both men, Clinton soon learned he could not escape issues from abroad..$^{90}$

Shortly after his inauguration, Islamic terrorists conducted an ambitious bombing attack against the World Trade Center in New York City. The attack killed six Americans and though it did not achieve the mass killings hoped for by the terrorists, it signaled a dramatic new threat against the American people. Over the summer and fall, crises in Haiti and Somalia intensified, the latter costing eighteen soldiers their lives and leading Secretary of Defense Les Aspin to offer his resignation. Ethnic violence in Bosnia, for which Clinton had criticized Bush, continued unabated. As it gained attention in the news, Clinton lamented that the media was trying to force him into a war he did not want. By mid-1994, none of these crises had faded away and two new

tremendous showing for a third party candidate. "The Economy, Stupid," was one of three things James Carville listed on an office sign to focus campaign workers. One also sees it as: "It's the economy stupid!"

${ }^{90}$ Rodman, 203 and 205; Talbott, The Russia Hand, 5 and 131; Fraser Cameron, U.S. Foreign Policy After the Cold War: Global Hegemon or Reluctant Sheriff. 2d. (New York: Routledge, 2005), 22. 
ones_-genocide in Rwanda and nuclear tensions with North Korea emerged. Clinton learned, as had Truman before him, that though he might want to be a domestic president, foreign affairs were unpredictable, distracting, and not likely to oblige him by staying on the back burner. ${ }^{91}$

Whether criticism about his level of interest is fair or not, Clinton did articulate and actalbeit in reverse order once or twice - in accordance with specific concepts. At his confirmation hearing, Secretary of State-nominee Warren Christopher told Congress three principles would guide U.S. diplomatic efforts in an environment in which "foreign and domestic policy must be addressed simultaneously." First, the United States must sustain its military strength, to "harness force with diplomacy." Second, the Administration would focus on U.S. economic securityimproving competiveness, strengthening the bond between business, labor, and government, and improving access to global markets. Third, the United States should expand the footprint of democracy, generating stability and economic opportunity between like-minded states. The latter two became the foundation of the "engagement and enlargement strategy." 92

In September 1993, Clinton, Christopher, Madeline Albright, and Anthony Lake gave a series of speeches to refine these concepts. Interestingly, Lake, the National Security Advisor, gave the speech most closely associated with the Administration's national security approach. Lake intended his speech to be "Kennan-esque," even holding a "sweepstakes" to construct a catch phrase that could replace "containment." In his speech, entitled "From Containment to Enlargement," he reviewed the challenges then facing the country, spoke of the need to remain engaged, and then defined "enlargement" in broad terms. Lake said the "successor to a doctrine

\footnotetext{
${ }^{91}$ Rodman, 220 and 230. A month before the attack, Aspin disapproved a request to deploy heavy equipment to Somalia. Whether it could have helped is not clear, but Congress held him responsible and Clinton announced Aspin's resignation in December, "for personal reasons" He died a year later.

${ }^{92}$ Christopher, In the Stream of History: Shaping Foreign Policy for a New Era, 24; Douglas Brinkley, "Democratic Enlargement: The Clinton Doctrine," Foreign Policy (Spring 1997): 113. Clinton did not publish a National Security Strategy (NSS) until eighteen months after taking office. There are, however, a series of speeches, starting with this confirmation hearing that provide insight into his vision.
} 
of containment must be a strategy of enlarging the world's free community of market democracies" and, confident the public was ready for "ideapolitik as well as realpolitik," he established a rationale of values-based activism. In time, Clinton proved much more willing than his predecessors had been to intervene to protect human rights and to restore or prop up emergent democracies. As a result, the Clinton Administration found itself, particularly as it led the United States into Haiti (1994), Bosnia (1995), and Kosovo (1999), in a perpetual debate on the role of national values in defining national interests. ${ }^{93}$

Simultaneously, Clinton wrestled with changes in Russia; it seemed, in every overseas issue, Russia was the backdrop. Clinton was anxious to avoid any label that suggested he "lost Russia" - as Truman had "lost China" to the communists in 1949—-but was unsure how he could balance the economic aid the Russians required with the domestic agenda he wished to pursue. Many had made the assumption that a peace dividend, money formerly dedicated to Cold War-era defense and aid programs, was available for domestic programs only to have Christopher tell them, rebuilding Russia "is not less important to our well-being than the need to contain a hostile Soviet Union." Helping them is not charity, "but a security concern of the highest order." Some opponents criticized Clinton for not doing enough; others for the closeness of his relationship with Russian President Boris Yeltsin. There seemed no right answer. ${ }^{94}$

${ }^{93}$ William G. Hyland, Clinton's World: Remaking American Foreign Policy (Westport, CT: Praeger Publishers, 1999), 23; Anthony Lake, "From Containment to Enlargement," Vital Speeches of the Day 60, no. 1 (October 1, 1993): 13-19; Strobe Talbott, "Democracy and the National Interest," Foreign Affairs 75, no. 6 (1996): 47-63; Brinkley, 114-116. Madeline Albright was then Ambassador to the United Nations. Some, including Hyland, believe Lake, Talbott, and other members of the Administration saw the opportunity to improve the world as penance for Vietnam. In one sentence, Lake mixes the words doctrine, policy (i.e., containment), and strategy. Imprecision in words here illustrates part of the challenge in pursuing a grand idea; no one knows what it is they seek as doctrine, policy, and strategy are not the same.

${ }^{94}$ Brown, 591-592; Christopher, "International Peace"; Talbott, The Russia Hand, 8-9 As Truman had "lost China" in 1949 according to his Republican opponents. For another example of there being no right answer, consider that Clinton allies who had condemned his predecessors for using military force excessively criticized him for not using force quickly enough in Bosnia. Then, when Clinton intervened in Bosnia, former President Jimmy Carter implied the Administration was racist for not doing the same in 
As had Bush, Clinton sought solutions in institutions. Though he cautioned the United Nations (U.N.) about trying to be involved in all places, at all times, he believed in its mission and sought ways to support it. During the campaign, he had even endorsed a permanent international rapid reaction force, an idea that never garnered Congressional or Pentagon support. In Europe, the Administration was an early advocate of NATO expansion. The alliance struggled to identify its post-Cold War role and its inability to respond to the crisis in Bosnia had shaken confidence in its ability to do so. Like Helmut Kohl, the German Chancellor, Clinton believed NATO needed to expand as a means of integrating selected former Soviet Republics and former members of the Warsaw Pact with Europe. Should NATO exclude these countries, they reasoned, the division that burdened Europe for forty years would continue. The Russians opposed any expansion and ultimately, the Administration offered a partnership program, "Partnership for Peace" as a temporary compromise. ${ }^{95}$

Clinton also worked towards greater economic integration. He inherited the North American Free Trade Agreement (NAFTA) and Uruguay Round of the General Agreement on Trade and Tariffs (GATT), but revised them, supported both, and navigated them through Congress over opposition in both political parties. He strengthened the Asia-Pacific Economic Council (APEC), expanding its membership by a third and bringing Russia and Vietnam, former

black Africa. Truly, on national security, it seems difficult to satisfy everyone, even in one's own party. See McDougall, Promised Land, Crusader State, page 202.

${ }^{95}$ Brown, 589, 592-593; Talbott, The Russia Hand, 92-101; Brinkley, 112-113; “The Alliance's New Strategic Concept," North Atlantic Treaty Organization Official Texts, http://www.nato.int/cps/en/ natolive/official_texts_23847.htm (accessed February 11, 2014). NATO published a "New Strategic Concept" after a yearlong review. It said the risks against the alliance and its members were "less likely to result from calculated aggression against territories of the Allies, but rather from the adverse consequences of instabilities that may arise from the serious economic, social and political difficulties, including ethnic rivalries and territorial disputes, which faced many countries in Central and Eastern Europe." Still, it offers little to address those issues or that would prepare it for Bosnia, Kosovo, or Afghanistan. The Warsaw Pact was the Soviet-led alliance opposite NATO during the Cold War. It included Bulgaria, Hungary, Rumania, Czechoslovakia, Poland, and East Germany. When it collapsed, these, plus the former Soviet Republics of Lithuania, Estonia, and Latvia, sought NATO membership. 
outliers into the fold. Simultaneously, Clinton ensured the G-7 invited Russia into membership, a step up from associate membership offered by Bush. Domestically, Clinton made a change to the national security structure, creating the National Economic Council, a near-peer counterpart of the NSC to address economic policy and coordination issues within the federal government. Clinton made economic integration a priority, yet even this focus yielded criticism. Leslie Gelb, Council on Foreign Relations President, noted that Clinton had done well, but cautioned, "a foreign economic policy is not a foreign policy and it is not a national security strategy. ${ }^{\circ 6}$

The Clinton Administration began with a clear statement on principles and it ended with a similarly strong, if more wide-ranging, statement on purpose. Later known as the Clinton Doctrine, in 1999 the President gave a speech and published a NSS in which he defined national interests broadly, extending them to unstable areas once or twice removed from American vital or national interests. Neither the speech nor the NSS contained new ideas-Lake introduced them; Clinton used them as justification for intervention in Haiti and Bosnia- but they encapsulated the "progressive internationalist pragmatist" moniker Clinton wished for himself. Under Clinton, the United States would not allow conflicts, ethnic violence and genocide to "fester and spread" so while it could not be all things, in all situations, "where we can make a difference, we must be prepared to do so." The challenge was to deal with problems before they threaten national interests. For example, in Bosnia and Kosovo, not themselves U.S. interests, internal violence threatened the greater security of Europe, an American vital interest, and therefore if the United States and its allies had the means to act they must in an attempt to calm the situation. ${ }^{97}$

\footnotetext{
${ }^{96}$ Brinkley, 112-113.

${ }^{97}$ William J. Clinton, "Remarks on Foreign Policy” (San Francisco, February 26, 1999), https://www.mtholyoke.edu/acad/intrel/clintfps.htm (accessed March 9, 2014); The White House, $A$ National Security Strategy for a New Century, by William J. Clinton (Washington, DC, 1999), 2, 26, and 49; Cameron, 19. A "progressive internationalist pragmatist" is term Clinton used to describe his belief the U.S. must be actively engaged in the promotion of American values, but only within the limits of what it
} 
Doctrines themselves do not constitute policy or strategies, but broad descriptions of how an Administration understands U.S. interests and appropriate actions. Historians, legislators, political scientists, and journalists criticize Bush and Clinton for lacking vision, but both had visions. Bush chose to be practical, to embrace stability and pursue a deliberate path, yet struggled to articulate his choices in a way that resonated with others so seemed inattentive. Clinton weighed idealism with pragmatism, sought to export liberal values where possible, but was slow to make his case emphatically so seemed unfocused. If failing to capture the country's imagination like Truman and Kennan determines the Bush and Clinton legacies, it is reasonable to consider their faults as many have done. It is also important, however, to consider how changes amongst the policy elites, the media, and the Congress shaped their successes and their failures.

\section{The New Elites, Twenty-Four Hour News, and the Congress}

By the time Bush and Clinton had become President, the national security apparatus designed by the Truman Administration and the Eightieth Congress for the Cold War, though it had adapted to some degree, was largely unchanged. The Goldwater-Nichols Department of Defense Reorganization Act of 1986 had strengthened the Chairman of the Joint Chiefs, but structurally, those federal departments and agencies focused on national security looked much the same in 1993 as they did when Truman left office. Congress had attempted to restrict legislatively executive power through passage of the War Powers Resolution of 1973, but few questioned the presidents' role as lead on national security affairs. Outside the halls of government, the media and think tanks continued to affect U.S. policy, albeit more indirectly than the White House and

can practically achieve. It refers to the balance of "realpolitik" and "ideapolitik" Lake and Talbott first spoke about in 1993. 
Congress. Yet, despite appearances of sameness, the policy-making environment in which these two Administrations functioned was different from that of the Truman Administration. ${ }^{98}$

Historians generally credit the Bush Administration for having created the most effective national security team in the contemporary era. A witness to infighting between principals of the Reagan Administration, Bush carefully approached the selection of his team, placing a premium on temperament and ability to work with others. They disagreed on some issues, but the Bush team, the "Gang of Eight," communicated with each other, respected each other, and remained professional throughout their four years together. Their experience in elected and appointed office was valuable, providing them a perspective of the bureaucracy, domestic politics, and Cold War international relations. The team was a strength of the Administration though what the United States needed from 1989-1992 were not Cold War experts, but policymakers ready to respond to and direct the "new world order" about which they spoke. ${ }^{99}$

The task of managing the first years of the post-Cold War period fell on the Clinton Administration and the team of Christopher, Strobe Talbott, Anthony Lake, and Madeline Albright. Like their predecessors, all had experience in government, particularly in the Carter-era

\footnotetext{
${ }^{98}$ Goldwater-Nichols reformed the Joint Staff, removing operational control of forces from the services and investing it in the combatant commanders, creating the Vice Chairman position and formalizing the Chairman's position as the senior military advisor to the President, senior in rank to the Service Chiefs. See http://www.ndu.edu/library/goldnich/goldnich.html. The War Powers Resolution of 1973 intends to limit the ability of the President to deploy troops into combat without the consent of Congress. There is debate on its constitutionality and Presidents have tended to give it as little attention and legitimacy as possible. See http://www.law.cornell.edu/uscode/text/50/chapter-33.

${ }^{99}$ James M. Scott, "Interbranch Rivalry and the Reagan Doctrine in Nicaragua," Political Science Quarterly 112, no. 2 (Summer 1997): 237-260; David Rothkopf, Running the World: The Inside Story of the National Security Council and the Architects of American Power (New York: Public Affairs, 2005), 260-301; Rodman, 180; Baker III and DeFrank, 27; Robert M. Gates, From the Shadows (New York: Simon \& Schuster, 1996), 293-316. Baker, Herspring, Gates, Rothkopf, and Scott discuss problems between the principals of the Reagan Administration. The "Gang of Eight" included Vice President Dan Quayle; Secretary of State James Baker; Secretary of Defense Dick Cheney; National Security Advisor Brent Scowcroft and his Deputy, Robert Gates; John Sununu, White House Chief of Staff; Larry Eagleburger, Deputy Secretary of State; and General Colin Powell, Chairman, Joint Chiefs of Staff. It might have been difficult to sustain this team because rarely do individuals remain in a cabinet position for eight years. In fact, Baker left State to run the White House six months before Bush left office.
} 
State Department and National Security Council. Historians generally give this Administration lower marks than they do its predecessor. Most of this criticism targets Clinton himself on several points. First, Clinton liked to forage around for ideas, a process that prolonged meetings for hours and lent itself to complaints he lacked focus. Second, some questioned the depth or consistency of his decisions, accusing him of placing too much weight on polling data and struggling between an “allergy to military intervention ... and activist interventionism." Finally, critics questioned his initial nominees for Secretary of Defense and State. Aspin and Christopher were capable men, but chosen to avoid overshadowing the President and his domestic agenda. Neither seemed suited to run the bureaucracies placed in their care. ${ }^{100}$

As a matter of style or a reflection of confidence in the strength of his team inside the government, Bush relied less on think tanks than did his successor. Clinton valued the personal contacts he made and the conversations held outside the government and sought them out. After Walter Mondale lost the presidential election in 1984, Clinton joined conservative Democrats to form the Democratic Leadership Council (DLC) to promote "progressive ideals, mainstream values, and innovative, non-bureaucratic, market-based solutions.” In 1989, the DLC formed a think tank, the Progressive Policy Institute. It then published a document, Mandate for Change, which Clinton embraced as the basis for his domestic and national security policies. In addition, Clinton routinely participated in "Renaissance Weekends," "unusually candid ... always provocative" gatherings of "thought-leaders, trend-setters and authorities" from across the

${ }^{100}$ Dale R. Herspring, The Pentagon and the Presidency: Civil Military Relations from FDR to George W. Bush (Lawrence: University Press of Kansas, 2005), 333 and 338; Hyland, 19; Rodman, 205 and 209. Talbott was a Russian expert, close Clinton friend, and Deputy Secretary of State (1994-2001), Lake was National Security Advisor (1993-1997), and Albright was Ambassador to the U.N. (1993-1997), then Secretary of State (1997-2001). 
political and professional spectrum. As mentioned, Clinton enjoyed the intellectual challenge of foraging for ideas; groups like the Renaissance Institute enabled that pursuit. ${ }^{101}$

If membership by key elected and appointed officials reflected degree of influence, the dean of internationally focused think tanks, the Council on Foreign Relations (CFR), had lost no ground. Every member of the Bush and Clinton national security teams were members, some not until after their service in this period, but others, like Warren Christopher, well before this period. Still, the Council had changed since Truman was in office and these changes hint at fundamental differences in the body of people whom determined national security strategies in and out of government. These changes, which some credit to the Vietnam War experience, may have been as significant to the formation of policy as the complexity characterizing the post-Cold War international environment. ${ }^{102}$

In 1984, I. M. Destler, Leslie Gelb, and Anthony Lake published a book, Our Own Worst Enemy [hereafter Worst Enemy], lamenting the lack of consistency and coherence in American policy-making. They observed that shortsightedness, driven in part by the electoral cycle, but also

\footnotetext{
${ }^{101}$ Donald E. Abelson, A Capitol Idea: Think Tanks and US Foreign Policy (Montreal: McGillQueen's University Press, 2006), 36-39; Douglas Jehl, “Clinton, Others Begin 5-Day 'thinking Party'," Los Angeles Times, December 30, 1992, http://articles.latimes.com/1992-12-30/news/mn-2596_1_renaissanceweekend (accessed February 11, 2014); "The Weekends," Renaissance Weekend, http://www.renaissance weekend.org/aboutus/aboutus.htm (accessed February 4, 2014). "Agenda for a New Administration," "Building an Inner Life," and "You'd Never Guess: What Only My Friends Know About Me" are examples of the topics scheduled for the 1992 Renaissance Weekend. There were over 500 guests including Supreme Court Justice Harry A. Blackmun, former White House Communications Director David Gergen, Indiana Gov. Evan Bayh, Control Data Corporation Chairman Lawrence Perlman, former President Bush speech writer Peggy Noonan, Education Secretary-designate Richard W. Riley, U.S. Court of Appeals Judge Patricia Wald, retired Army General Evelyn Foote, Attorney General-designate Zoe Baird, Olympic gold medalist Edwin Moses and theologian Michael Novak.

${ }^{102}$ Destler, Gelb, and Lake, 18-19. These authors are distinguished students of foreign policy. Destler, a professor at the University of Maryland, has been active in several think tanks (Peterson Institute for International Economics, Carnegie Endowment for International Peace, Brookings Institute, and the Council on Foreign Relations) and counseled the Executive Office of the President and the Department of State. Gelb held several policy positions in the Departments of Defense and State during the Johnson and Carter Administrations. When not in government, he was diplomatic correspondent at the New York Times (1973-1977, 1981-1993) and President of the Council on Foreign Relations (1993-2003). See Annex A: Biographical Summaries to learn about Anthony Lake.
} 
by the tendency of the American people to focus on immediate, not long term, issues had always hampered U.S. efforts to develop and implement long-term strategies. In the past, however, good fortune in geography and predominance in military and economic power had masked these weaknesses. Now, they wrote, repercussions from the Vietnam War exacerbated American flaws precisely when "mistakes hurt more, and the wounds are not so easily healed." Recognizing there can be no return to the past, the authors address changes amongst the elite, the media, and the Congress before making a single broad recommendation for the future. ${ }^{103}$

Worst Enemy starts its analysis on the elites of American society responsible for foreign and domestic policy. Early in the Cold War, these elites, drawn from the "Eastern Establishment" of rich, white, Ivy-league educated professionals (Acheson, Harriman, Lovett) and career public servants (Marshall, Kennan), tended to be centrist in their thinking, practical and limited in their approach, and reluctant in their pursuit of public attention. In the years after Vietnam, however, the corps of policymakers looked much different. The "Professional Elite," full time policy experts from academia (Kissinger, Brzezinski, Lake), think tanks and the print media (Talbott), became more influential, and supplanted "Establishment" figures. They may have read more, but they had experienced less; none, for example, could match Kennan in the education he gained living with and studying the Soviets for twenty years. The new elite wrote more, even prolifically, seemed more interested in celebrity, and were disposed to see their environment through ideologically colored lenses. As such, party affiliation mattered more, they rotated in and out of government as the White House changed hands, and continuity suffered. ${ }^{104}$

\footnotetext{
${ }^{103}$ Ibid, 12, 15, and 26-27.

${ }^{104}$ Ibid, 91-93, 98-101, and 123. Marshall does not meet the traditional definition as an "Eastern Establishment" personage, but in conduct and service, he fits the mold.
} 
Even the Council on Foreign Relations (CFR) felt the change. In 1958, Harper's Ferry said the Council played a "special part in helping bridge the gap between parties," but ten years later, it began to fracture over Vietnam. At the same time, Foreign Policy, founded by Samuel Huntington and Warren Manshel, emerged as a competitor to Foreign Affairs. In an attempt to remain viable, CFR expanded its membership beyond its traditional base - the Establishment but at the cost of cohesiveness and confidentiality. Upsetting the extreme left and the right, membership became a stigma as consensus lost its way in stiffening ideological arguments. Think tanks, like the Washington-based Brookings Institute, who professed impartiality, but looked more and more like governments-in-exile for the political party out of power, became the new model and formed the role think tanks played in developing government policy. ${ }^{105}$

Between the Truman and Bush-Clinton eras, the media underwent three major changes. First, broadcast television replaced newspapers as a primary source of news for many Americans. Second, skepticism about the Vietnam War and the impact of Watergate led to changes in the way journalists reported the news. Third, the advent of twenty-four hour news, led by the Cable News Network (CNN) in 1980, rapidly accelerated the news cycle. Many politicians, not the least Bush and Clinton, learned a new golden rule: "better [or more] information for the public does not necessarily mean better decisions by policymakers." Generally, these changes proved to make policymaking more difficult, not easier. ${ }^{106}$

There is speculation on the degree to which the news media shaped policy and policyrelated decisions. Following the troubled intervention in Somalia (1992-1993), the term "CNN

\footnotetext{
${ }^{105}$ Ibid, 107-110. At its founding, Foreign Policy was an international relations-focused academic journal to "question commonplace views and groupthink and to give a voice to alternative views about American foreign policy."

${ }^{106}$ Lawrence Eagleburger, et al., interviewed by Stephen Hess, January 16, 2002, page 13 of transcript.
} 
Effect," suggesting the power of continuous, instantaneous news coverage, emerged. Proponents argued, "CNN got us into Somalia, and CNN got us out." Skeptics point out that news coverage on the humanitarian crisis had been sparse before Bush decided to intervene, rose dramatically immediately afterwards, and the tapered to nothing a month or so later. Lawrence Eagleburger, who succeeded Baker as Secretary of State and was therefore part of the decision to intervene, acknowledged the media's ability to influence the public could not be ignored, but insisted the choice was more complicated than any justification the "Effect" alone could provide. Perhaps Eagleburger is correct for that instance, but it seems likely that images of American soldiers dragged through the streets of Mogadishu had a large role in the decision to end the Somalia mission. Furthermore, as shown earlier, Clinton clearly felt the media was attempting to influence his decision on Bosnia. Perhaps what matters most is not whether the "Effect" exists, but rather the belief many hold that it does. ${ }^{107}$

Unfortunately, shock value and ubiquity might not be the worst impacts television media has on national security and domestic decisions. Whichever comes first - the short attention span of the people or the tendency of television to shorten attention spans - they feed on each other. Television has the unique ability to make its viewers feel as if a thirty- or sixty-second report or "soundbite" contains all of the critical information needed to make an informed decision. They come away impressed that "solutions, often absurdly simple, exist for deeply complex problems" for which there may be no answer, much less a simple one. Moreover, one must ask what impact

\footnotetext{
${ }^{107}$ Jon Western, "Sources of Humanitarian Intervention: Beliefs, Information, and Advocacy in the U.S," International Security 26, no. 4 (Spring 2002): 114; Eagleburger interview, 4. Anecdotes about the media abound. In his memoir, Baker recalls a visit to the Soviet Foreign Ministry when Chief Policy Aide Sergei Tarasenko turned to CNN, not his nation's intelligence services, to get the latest information on Iraq's invasion of Kuwait. Says Eagleburger: "My point is, when you try to manage foreign policy in a democracy you forget at your peril that there are a bunch of people out there that may vote your President out of office and in my case they did. Not for those reasons, I think. But you can't ignore it. You may not always accept it but you can't ignore it."
} 
editors have when, as they did for the Mogadishu story, they air two to three seconds of footage from minutes or hours of videotape. It also seems likely the rush to replace old headlines with new ones "every hour, on the hour," reduces the depth of analysis put into any report. ${ }^{108}$

Television had become an accelerant, impediment, and an agenda-setting agent all at once. In the first case, its images incite emotion, shorten decision-making response time, and magnify the words and actions of its subjects. In the second, it impedes policy- and decisionmaking as key officials wrestle with whether and how the media will cover their action or inaction. In the last case, media coverage, particularly painful images of suffering or injustice, can prompt action. Unlike Somalia, reports of massacres within Bosnia preceded U.S. intervention justifying Clinton's suspicion the media sought action to stop the violence. ${ }^{109}$

As twenty-four news gained traction, it also changed the focus of its coverage. Major newspapers, especially the New York Times and Washington Post, continued to devote considerable effort on national security issues, but television networks did not. Perhaps reflecting the inward focus of their audience, the output of major network foreign bureaus in 2000 was onethird what it had been in 1990. By 2000, mainstream press organizations dedicated only one to two percent of their stories to foreign affairs. CNN Headline News, originator of the "Effect," wrapped its international news into "The Global Minute." CNN told viewers all they needed to know about the world's major challenges in sixty seconds and followed it with the latest from Hollywood. Informed interest had never been a strength of the American people, but television relegated "foreign policy into a subdivision of public entertainment." 110

\footnotetext{
${ }^{108}$ Jay Winik, “Quest for Bipartisanship: A New Beginning for a New World Order,” in U.S. Foreign Policy After the Cold War, edited by Brad Roberts, 311-326 (Cambridge, MA: MIT Press, 1992), 323; Eagleburger interview, 7.

${ }^{109}$ Eagleburger, 5; Destler, Gelb, and Lake, 153.

${ }^{110}$ Cameron, 104-105 and 109; Destler, Gelb, and Lake, 27.
} 
Finally, Congress looked and behaved differently after the Cold War than it did at the onset. The experience in Vietnam, followed so closely by the Watergate scandal, damaged whatever faith existed between the White House and the Congress. To reassert itself, Congress attempted to limit executive power and increase oversight activities. Doing so created more work, to manage this work Congress needed larger staffs, and larger staffs possessed even greater capability to travel, investigate, demand and process more information, reports, and testimony from the Administration. In 1960, the Senate Foreign Relations Committee employed twenty-five staff members; by 1975, this had more than doubled to sixty-two. Very few Senators in 1966 retained a foreign-policy specific staff member, but by 1984, virtually all did and in many cases, the Senator had hired the individual away from the Department of State. ${ }^{111}$

As the White House and executive bureaucracy struggled to maintain pace with the emergent Congressional professional staff, it also found itself attempting to manage an increasingly decentralized Congressional body. The number of committees and subcommittees grew, traditional rules of seniority lapsed, and all 535 members pursue agendas seemingly independent of each other. Congressional leaders Robert Dole, Dick Gephardt, Richard Lugar, Sam Nunn, and Robert Byrd exerted significant influence, but not to the degree exercised by Sam Rayburn or Arthur Vandenberg many years before. When it only took one junior Congressman to stall or derail a key piece of legislation, the absence of veteran legislators complicated any serious effort to build and maintain consensus. ${ }^{112}$

Even as Congress expanded oversight, it seemed unable to sustain its interest and unwilling to accept accountability for its role national security issues. By 2000 , less than half of

${ }^{111}$ Destler, Gelb, and Lake, 136-139, 145-148, and 150; Winik, 316. A list of staff salaries in 2013 lists seventy-seven employees of the SFRC professional staff. See http://www.legistorm.com/office/Senate _Foreign_Relations_Committee/683/189/salary/asc.html (accessed May 5, 2014).

${ }^{112}$ Haass; Winik, 316-317. 
the House and Senate had entered office more than eight years before. Like Clinton, they entered federal office after the Cold War and they shared his focus on domestic, not international issues. Though at one point, all seven subcommittees of the Senate Foreign Relations Committee had first term Chairmen - a sign even veteran Senators had lost interest—most newly elected Senators were more interested in Finance, Banking, Commerce, and Judiciary Committees than Foreign Relations. Congressional leaders travelled less and funded diplomatic efforts sparingly. Senator Pat Roberts, himself new to the Senate, told a Texas audience in 1998 that "not since the 1930s ... has Congress been so insular and isolationist." The internationalist wing of the Republican Party made popular by Vandenberg, Eisenhower, Reagan, and others was "barely represented."113 Baker, Scowcroft, and Christopher recognized the challenges they faced with Congress and expressed interest in improving cooperation between their offices and Congress. Baker and Scowcroft established legislative liaison offices at State and in the NSC as part of an effort to establish "bureaucratic and procedural mechanisms for consultation." Christopher, who as Deputy Secretary of State in the Carter Administration suggested a combat between the Executive and Congress, considered himself, as Secretary of State, "Chief, America Desk" and assigned himself the task of coordinating with Congress and educating the public. His compact had argued that the White House and Congress had complementary, not competitive, constitutional responsibilities demanding cooperation and bipartisanship. ${ }^{114}$

Results varied. With no Congressional support, none of the accomplishments listed earlier would have taken place. As the vote for the use of force against Iraq in 1991 demonstrates however, it was never easy. In this instance, $82 \%$ of the public supported the resolution, yet only

\footnotetext{
${ }^{113}$ Cameron, 69-71 and 78; Haass

${ }^{114}$ Winik, 319-320; Bush and Scowcroft, 31; Christopher, In the Stream of History: Shaping Foreign Policy for a New Era, 16.
} 
ten Democrats (out of fifty-six) did so and the measure barely passed, 52-47. The fight to pass NAFTA in late 1993 was equally hard and the vote much closer than Clinton preferred. On the other hand, issues like formal recognition of Vietnam proved that bipartisanship leadership could make easier a very emotional issue for many Americans. In the balance, however, cooperation was rare. It is perhaps illustrative that Baker's autobiography has less than ten references to the Congressional leadership; Christopher's has slightly more, but also has nearly as many references to Marshall and Kennan as it does to opposition leaders in the Congress. ${ }^{115}$

Our Own Worst Enemy does not explicitly include the American people as part of the problem, though by implication, it is not possible to overlook their responsibility. How Americans select their leaders, whom they select, and how their habits drive media practices makes a difference. Ample polling data suggests Americans lack knowledge, not access to information, on the international community and practice suggests they are satisfied dedicating increasingly shorter amounts of time to the study of major news items and issues that affect their lives. They express poor opinions of elected officials, yet seem disinterested in making personal choices — removing their elected official — that prompt change. Our Own Worst Enemies identifies the worst in the institutional side of policymaking; regrettably, it lets the people themselves off the hook.

Destler, Gelb, and Lake believed "American foreign policy is in a perpetual state of crisis" not simply because the world was more complex, but because of systemic breakdowns in all facets of policymaking. They perceived a government in disarray, its officials polarized by ideology, short of credibility, interested in the quick fix and political theater, and neither able nor

${ }^{115}$ Winik. 315 and 321; Christopher, In the Stream of History: Shaping Foreign Policy for a New Era, 302-303, and 305; Baker III and DeFrank. Winik suggests the "perception of division and weakness at home [on the Senate vote] made the necessity of a military solution almost inevitable." Notably, Truman received bipartisanship support on $2 / 3^{\text {rds }}$ of the foreign policy issues Congress addressed; Reagan received support on only $1 / 7^{\text {th }}$ of those he presented to Congress. 
interested in building compromise. Their indictment, written before the emergence of the most notorious contemporary scandals and the brutal partisan hostility that characterized closures of the government years later, is damning and pessimistic. What then must the United States do to reclaim the success achieved in the post-WWII era? A review of this question and potential answers is the focus of the final chapter in this monograph. ${ }^{116}$

${ }^{116}$ Destler, Gelb, and Lake, 261-272. This book followed the Vietnam War and Watergate (Nixon, 1973-1974), but it preceded Iran-Contra (Reagan, 1985-1987), Savings and Loan (Congress, 1988-1989), Whitewater (Clinton, 1992-1998), government closure (Clinton and Congress, 1995-1996) and Monica Lewinsky (Clinton, 1998) incidents. Considering these, the government offered its constituents ample reason to question the integrity, selflessness, and efficiency of their elected and appointed officials. 
The inconstancy of American foreign policy is not an accident but an expression of two distinct sides of the American character .... . one is the morality of decent instincts tempered by the knowledge of human imperfection and the other is the morality of absolute self-assurance fired by the crusading spirit.

- J. William Fulbright, The Arrogance of Power ${ }^{117}$

\section{CONCLUSIONS}

One needs look no further than the developing crisis in Ukraine, where Russian troops have seized control of the Crimea, to see that many of the same issues described in the preceding chapter continue to plague American national security policymaking. In one recent article, presidential advisors, members of Congress, retired military officers and independent policy analysts each present dissimilar, uncoordinated responses to the same event. Their differences are not solely in degree, but of substance. Some advocate economic sanction against Russia, others argue for the introduction of missile defense systems in Eastern Europe, and one outlier, a retired, former Supreme Allied Commander, Europe, insists a military response must remain an option. It is entirely too early to forecast how the United States and its allies will respond, if they do at all, but this current example highlights how differing perspectives - some better informed than others - on interests, means, and ends complicates adoption of a single idea or policy everyone can embrace. Furthermore, the article contains more than a passing suggestion that many political figures and policy experts hold President Barak Obama, in failing to lead with vision and consistency, partially responsible for the crisis. The article hardly reflects the fiercely debated, but in the end, respectful and closely coordinated, "politics stops at the shore" approach adopted by President Harry Truman and Senator Arthur Vandenberg following WWII. ${ }^{118}$

\footnotetext{
${ }^{117}$ J. William Fulbright, Arrogance of Power (New York: Random House, 1966), 245-246.

118“"UN Ambassador Powers Says Russia Intervention 'Must Stop'; Moscow Defiant," Fox News; Associated Press, March 3, 2014, http://www.foxnews.com/politics/2014/03/03/obama-threatens-to-isolaterussia-on-ukraine-though-few-back-military-option/ (accessed March 3, 2014). Popular disinterest for such events continues. NewsWhip, which tracks news items in social medium (i.e., Twitter, Facebook, etc.), compared major newspaper front pages with what those pages would look like if constructed only with
} 
These very public debates of discordant ideas and sniping at fellow elected officials may be hallmarks of democracy, but they are not necessarily conducive to thoughtful policymaking. No one, least of all this author, advocates adoption of the current Russian model, but there is value in the advantages - opaqueness, unity of effort, and a resolute focus on interests - the Russians enjoy as they take the initiative in the Ukrainian crisis. The Truman Administration benefited from the last two of those advantages, but post-Cold War administrations have not been as fortunate. If then, the United States is to eschew Russian authoritarianism—and it certainly must - what must it do to regain unity of effort and a resolute focus on interests in an increasingly challenging international environment? There are several answers to this question. ${ }^{119}$

First, it should accept what it has been and is ideologically. Though young in comparison to other powers - the United Kingdom, the Russian Federation, the French Republic, and the Peoples' Republic of China inherited legacies established over a millennia or more - the United States possesses a rich collection of national security traditions on which it can rely. Too often, assessments of these traditions insert fashionable moral judgments into poorly understood historical context. As a result, traditions of exceptionalism, unilateralism, and expansionism carry negative connotations so powerful as to complicate their utility. Disgusted by failed or unpopular decisions in Vietnam, the Americas, and the Middle East, Americans lose sight of the purpose of these decisions - to defend American interests - and seem unwilling to make choices that make them uncomfortable. Still, "comfort [in choices] alone, however cannot be the [sole] criterion by which a nation shapes its strategy and secures it safety." Historically flawed, poorly executed,

online articles most frequently shared by readers. With one exception, Wall Street Journal, Washington Post, New York Times, and USA Today national and local stories of greater interest to the public replaced those on the Ukraine. See http://blog.newswhip.com/index.php/2014/03/people-powered-front-pages-rock.

${ }^{119}$ It is possible Russian President Vladimir Putin follows not state, but personal interests in much of what he does; it is not possible to know. This opaqueness, the ability to have conversations behind closed doors without public discourse or media scrutiny, is an advantage to such states. If it is not one worth trading for — and it is not — the United States must determine how to make the best of its challenges. 
misunderstood or morally bankrupt policies legitimize the need to oversee those responsible for policymaking; they should not justify rejection of the traditions inspiring those policies. On the contrary, in these collectively, the United States might find its grand idea. ${ }^{120}$

Second, the United States should undertake organized, deliberate, periodic reviews of its interests, strategies to achieve those interests, and organizations required to implement those strategies. In this regard, the Eisenhower Administration, not the Truman Administration, sets the standard for others to emulate. Soon after taking office, President Dwight Eisenhower questioned whether NSC 20/4 and its successor document, NSC 68, were sufficient to address the questions confronting the United States. He assembled leading national security experts from academia, the Defense Department, and the State Department, organized them into teams around three different strategic approaches, and challenged each to develop fully their assigned course of action in anticipation of defending it before the others. He insisted upon holistic options, measuring Soviet and American strengths and limitations across economic, diplomatic, and military domains. By creating constructive tension between the teams, Eisenhower improved the quality of their work and removed the possibility — likely had one team alone built three options — that he would receive "throwaway" options. After six weeks of work in absolute secrecy, the "Solarium Project" teams made their presentations to Eisenhower and senior national security officials. ${ }^{121}$

${ }^{120}$ John L. Gaddis, Surprise, Security and the American Experience (Cambridge, MA: Harvard University Press, 2004), 32-33. See Appendix C: American National Security Policy Traditions for a list of commonly recognized themes or traditions in American national security policy.

${ }^{121}$ Michele Flournoy and Shawn Brimley, "Strategic Planning for National Security: A New Project Solarium," Joint Forces Quarterly, no. 41 (2d Quarter 2006): 82-83. Eisenhower named it the "Solarium Project" after the White House room in which he conceived the idea. Whether the absence of Congressional leadership in the Project was an issue for Eisenhower in implementation is an area of future research. Perhaps it was of little concern because his party held majorities in the Senate and the House. The NSC captured Eisenhower's decision in NSC 162/2, published in October 1953. For more on Eisenhower, see Robert R. Bowie and Richard H. Immerman, Waging Peace: How Eisenhower Shaped an Enduring Cold War Strategy (New York: Oxford University Press, USA, 2000). 
After the presentations, everyone shared a common understanding of the environment, the options available to the President, and, once Eisenhower chose, the logic behind the option he adopted. It was as remarkable as what Truman accomplished, though more so for the technique than originality of its result because in some regards, the process was more important than the final product. As Daniel Drezner and others have observed, deliberate policymaking not only produces useful outcomes, its forms "patterns of thinking" that match resources to ends and prepares policymakers for new and unanticipated events. Whereas Truman had arrived at his doctrine unintentionally, through this deliberate process, Eisenhower achieved two objectives: a revised approach and, more importantly, improved analytical capability within his staff. ${ }^{122}$

Nearly sixty years after the "Solarium Project," Michele Flournoy and Shawn Brimley, policy experts at the Center for Strategic and International Studies, wrote "Strategic Planning for National Security: A New Project Solarium.” They argued the nation still lacked an interagency process that could ensure "national security decision-making is informed by the long view ... [and lacked] adequate mechanisms ... to ensure that national security resources are actually allocated and spent" according to articulated priorities. The United States, they argued, is "at a crucial point, facing new and challenging threats as well as unprecedented opportunities" it was unprepared to address. It needed a "considered assessment of the future security environment and how the nation can best protect and advance its strategic interests." 123

Championing a recommendation by a post-September 11, 2001 report that called for "routinizing, even bureaucratizing, the exercise of imagination," Flournoy and Brimley proposed several organizational and procedural reforms designed to promote Solarium Project-type work

\footnotetext{
${ }^{122}$ Daniel W. Drezner, ed., Avoiding Trivia: the Role of Strategic Planning in American Foreign Policy (Washington, DC: Brookings Institution Press, 2009), 4. This book, a collection of essays, covers many of the same topics and solutions covered in this paper. It is well worth the read.

${ }^{123} \mathrm{Ibid}, 86$.
} 
within the Executive Branch. These include quadrennial national security reviews supported by an interagency threat assessment process, semiannual "over the horizon" reviews, annual tabletop exercises for senior officials, and biennial publication of a classified national security planning guidance to inform departmental activities. Amongst these ideas is an implicit notion that requirements to produce a National Security Strategy (NSS) annually are excessive, dilute the quality of work, and encourage the White House to ignore them altogether. Equally implicit is the assumption that future presidents, like Eisenhower, can chose the right people to draft these reports as rarely does bureaucratizing a process increase the creativity found in the product. ${ }^{124}$

Flournoy and Brimley also propose creation of a strategic planning cell within the National Security Council (NSC) and mission area reviews, led by the NSC and Officer of Management and Budget (OMB), to identify gaps, seams, duplicated and misaligned efforts in "high priority mission areas." Perhaps these too are useful, but likely, they only scratch the surface of the institutional reform required within the Executive Branch. The reorganization of government led by the Truman Administration was bold, sweeping, and important to the conduct of national security. Except for the Goldwater-Nichols Act of 1986-which reorganized the Joint Staff — and the Homeland Security Act of 2002 — which established the Department of Homeland Security - there have been no substantive efforts to match national security structures to present day challenges. Even the Homeland Security Act, considered the most significant reorganization since 1947, merely rearranged —inadequately many would argue — offices rather than thoroughly reviewing needs, rearranging authorities, and improving structure. ${ }^{125}$

\footnotetext{
${ }^{124}$ Ibid, 85-86. Flournoy, the Under Secretary of Defense for Policy in the Obama Administration, like her predecessors made little progress in bringing about the changes she had advocated from the relative safety and open environment of a private think tank.

${ }^{125} \mathrm{Ibid}, 86$. If Flournoy and Brimley believe a single planning cell can replicate Solarium, they overlook the dynamic Eisenhower created with three independent teams. Still, it might be better than what is currently in place - nothing. In the first ten years after the end of WWII, the government passed the
} 
Enabling institutional reform is daunting and some skeptics doubt substantive change is possible. Amy Zegart, a public policy expert and alum of the Clinton National Security Council staff, believes policymakers face four insurmountable constraints to reform. First, they endure time pressures to satisfy immediate issues at the expense of long-term issues. Second, there are cognitive barriers to anticipating the future. Third, the government favors policymaking "doers" over policymaking "thinkers." Finally, bureaucratic competition for influence frequently carries more weight than doing what is best for the nation even when the solution seems obvious. ${ }^{126}$

As one example, consider the relative size, abilities and influence of the Department of State relative to other tools of national security. Despite widespread recognition that "the most important lessons of the wars in Iraq and Afghanistan is that military success [alone] is not sufficient to win," the United States continues to under resource its soft power capabilities in comparison to more muscular ones. In 2007, former Secretary of Defense Robert M. Gates called for a greater national commitment to "America's ability to engage, assist, and communicate with other parts of the world." He called for broad reconsideration of priorities, with greater focus on a more capable diplomatic corps, improved intelligence capabilities, and greater reliance on unconventional forces able not only to defeat the enemy, but also to prepare friendly states to do the same without American intervention. His speech was a recognition that sixty years after the last sweeping reform of national security organizations it was time to reform them again. Today, however, defense spending continues to dwarf State Department spending by more than twenty

National Security Act of 1947 and asked former President Herbert Hoover to lead two Commissions on Organization of the Executive Branch of the Government (1947 and 1953). The first Commission made 273 separate recommendations; the Truman and Eisenhower Administrations adopted 196 of them. In 2006, Congress created the non-profit, now defunct "Project on National Security Reform" to replicate the Hoover Commissions in the area of national security administration. See its website, http://www.pnsr.org/, to review its achievements most of which are conceptual rather than substantive.

${ }^{126}$ Amy B. Zegart, "Why the Best is Not Yet to Come in Policy Planning," in Daniel W. Drezner, ed., Avoiding Trivia: the Role of Strategic Planning in American Foreign Policy (Washington, DC, Brookings Institution Press, 2009), 113-125. 
times and combatant commanders possess a disproportionate capacity for engagement relative to their Foreign Service counterparts. The system is out of balance for the needs it must address. ${ }^{127}$

Finally, policymakers must recognize, without disparaging, and mitigate, within constitutional limits, the policymaking challenges incumbent in a liberal democracy. Over two hundred years ago, Alexander Hamilton argued that the executive alone possessed the energy and focus to act with "decision, activity, secrecy, and dispatch" in international relations. Yet today, Congress, the bureaucracy, and the media form a formidable obstacle to the White House and prevent the president from exercising the energy Hamilton described. Congressional debate on the use of force in Afghanistan, Iraq, Libya, and Syria suggests that, in the absence of a clear and present danger, the cooperation found between the White House and the Congress during the Truman-era is the exception, not the norm. At the same time, non-governmental actors from the media and prominent think tanks continue to affect the direction, tone, and tenor of debate on most issues, occasionally with their own agenda and not always responsibly. In short, the issues Destler, Gelb, and Lake described are just as prevalent today as they were when their book went to print in 1984 . Their recommendations remain similarly relevant. ${ }^{128}$

${ }^{127}$ Robert M. Gates, “Importance of Soft Power” (speech, Kansas State University, Manhattan, KS, November 26, 2007), http://www.defense.gov/speeches/speech.aspx?speechid=1199 (accessed March 4, 2014). Since Gates' speech, outlays for the Department of State have nearly doubled to $\$ 32$ billion. Defense spending has remained relatively constant at around $\$ 600$ billion. See OMB Historical Table 4.1 at http://www.whitehouse.gov/omb/budget/Historicals/. See Dana Priest's The Mission: Waging War and Keeping Peace with America's Military (New York: W. W. Norton \& Company, 2003) for a detailed look at military diplomacy in the U.S.

${ }^{128}$ Carnes Lord, The Presidency and the Management of National Security (New York: The Free Press, 1988), 8. For comparison, the Congressional vote on the use of force against terrorists and states who harbored them (i.e., Afghanistan), passed the Senate, 98-0, and the House, 420-1, three days after the attacks on September 11, 2001. The vote on the use of force against Iraq still passed by a wide margin in both houses, but saw less Democratic support, particularly in the House. During the Libya crisis in 2011, the Democratic-controlled Senate passed a resolution asking for a U.N.-enforced no-fly zone, but the Republican-controlled House passed three separate resolutions rejecting participation in combat operations against the Libyan regime. In one last example, a scheduled vote on the use of force against the Syrian regime in 2013 never took place because the President failed to muster sufficient support from either party in either the House or the Senate. See https://www.govtrack.us/congress/votes. On the role of the media, 
Relevant, however, does not mean easily adaptable. Patience, discipline, and selflessness, words not commonly used to describe American politics, summarize the recommendations Our Own Worst Enemy offers. First, the authors reject "consensus in the form of . . doctrine[s]," saying the latter are useful for political purposes, but otherwise only stifle debate and limit choice by defining expectations of action when doing so is unhelpful. Second, the United States cannot recover the characteristics that guided it through the post-WWII era, but it can, by exploiting the strengths and limiting the excesses of the professional elite, reorganizing the bureaucracy, and exercising legislative restraint, work towards centrist national security policies reflective of its policy traditions. Third, political leaders and policymakers should approach an increasingly complex international environment with intellectual honesty, recognizing that they do not have and cannot have, all of the answers, and pragmatism. Especially as resources become strained, the United States must understand its own ability to affect change as well as the abilities of other nations. Finally, politicians and policymakers must be sensitive, but not hostage to political interests and posturing. The government can, these authors argue, end the "perpetual state of crisis" in which American foreign policy finds itself, but only if unselfishly led by its elected officials and faithfully served by a professionalized bureaucracy. ${ }^{129}$

Seventeen years after Our Own Worst Enemy, Dr. Henry Kissinger echoed some of these points. In a critique of the Clinton era, Kissinger rejected Congressional attempts to legislate international codes of conduct, criticized the media for trivializing national security issues, and

one need only study on media coverage of the murder of Ambassador J. Christopher Stevens in Benghazi, Libya to see that different editorial agendas influence the extent and substance of coverage. As for responsible coverage, during the Ukraine crisis in late February 2014, multiple news organizations carried "breaking headlines" that the Russian Federation had recalled their ambassador from the United States when in fact, its parliament had merely requested its president do so. Misleading headlines like these are inflammatory and unhelpful.

${ }^{129}$ Destler, Gelb, and Lake, 261, and 272-285. How interesting that Lake argued against pursuit of a single doctrine in 1984, yet when in a position to lead as National Security Advisor to President Clinton, violated his own council. 
lambasted Clinton's reliance on economic policy alone as national security policy. The United States, he argued, having conducted no serious debate on national security issues since the end of the Cold War, had been more lucky than good. Even worse, he continued, the debate, such as it was, focused on weighing the merits of idealism versus realism rather than seeking a balance between the two as complementary principles. Kissinger feared the extremes of realism doomed the United States to stagnation and that of idealism to adventurism. He argued the country was less in need of a "specific policy than of a long-range concept." Without such a concept, the “United States will drain its psychological and material resources . . [unable to] distinguish between what it must do, what it would like to do, and what is beyond its capabilities."130

Domestic resource constraints, challenging relations with an emergent Peoples' Republic of China and resurgent Russian Federation, globalization, violent extremism, failed and failing states, and weapons proliferation argue in favor of Kissinger's admonition. There are simply more problems in the world than solutions the United States can devise through happenstance and crisis management. It needs not doctrines or catch phrases, but a substantive long-range concept based on its national security traditions around which to focus its energies. Without focus, the United States risks dashing itself against competing and conflicting initiatives, not all of which address vital, national interests. The American post-WWII experience suggests, with the right mix of leadership, nonpartisanship, and reform, the United States can articulate and employ a unifying national security statement to guide it through the turbulent times in which it finds itself.

${ }^{130}$ Henry Kissinger, Does America Need A Foreign Policy? (New York: Simon \& Schuster, 2001), 19-20, 27, 30, 283. In response to the crisis in Ukraine, Kissinger wrote an article that is a useful illustration of how he balances idealism and realism. See Henry A. Kissinger, "How the Ukraine Crisis Ends," Washington Post, March 6, 2014, http://www.washingtonpost.com/opinions/henry-kissinger-tosettle-the-ukraine-crisis-start-at-the-end/2014/03/05/46dad868-a496-11e3-8466-d34c451760b9_story.html (accessed March 15, 2014). 


\section{APPENDIX A: BIOGRAPHICAL SUMMARIES ${ }^{131}$}

\section{Harry S. Truman Era (1945-1953)}

Acheson, Dean (born April 1893, died October 1971): Bachelors, Yale (1915); Juris Doctorate, Harvard University (1918); National Guard, stateside service during WWI; law clerk at U.S. Supreme Court (1919-1921); law practice (1921-1932, 1934-1941); Undersecretary of the Treasury (Roosevelt, 1933); Commission on Government Reform (1939-1940); Assistant Secretary of State (Roosevelt, 1941-1945); Undersecretary of State (Truman, 1945-1947); Secretary of State (Truman, 1949-1953)

Forrestal, James (born February 1892, suicide May 1949): attended Dartmouth College and Princeton University; U.S. Navy aviator during WWI with duty in Washington, DC; bond salesman, later partner, vice-president, and president at William A. Reed \& Company (19161940); Special Administrative Assistant to the President (Roosevelt, 1940-1943); Secretary of the Navy (Roosevelt, 1944-1947); Secretary of Defense (1948-1949)

Kennan, George F. (born February 1904, died March 2005): Bachelors, Princeton University (1925); Foreign Service Officer with multiple posts in Eastern Europe, Germany, and the Soviet Union (1926-1946); Professor, National War College (1946-1947); Director, Policy Planning Staff, U.S. Department of State (1947-1950); Ambassador to the Soviet Union (1951-1952); Ambassador to Yugoslavia (1961-1963)

Lippmann, Walter (born September 1889, died December 1974): Bachelors, Harvard University (1910); founding editor of The New Republic magazine (1913); U.S. Army (1918) with service in France; advisor to President Woodrow Wilson and Colonel Edward M. House and organizer of the Inquiry (1919-1920); author and syndicated journalist for The New York Times (1910-1967); two time Pulitzer Prize Awardee $(1958,1962)$

Marshall, George C. (born December 1880, died October 1959): Virginia Military Institute (1901); U.S. Army (General of the Army, 1901-1945) including Chief of Staff of the Army (1939-1945); Secretary of State (Truman, 1947-1949); Secretary of Defense (Truman, 19501951); Nobel Peace Laureate (1953); Time Magazine Man of the Year $(1943 ; 1947)$

Taft, Sr., Robert A. (born September 1989, died July 1953): Yale College (1910); Harvard Law School (1913); law practice (1913-1917); Food and Drug Administration (1917-1919); Ohio House of Representatives (1920-1930) and Senate (1930-1932); U.S. Senate (Ohio, 19381953) including Majority Leader (1953); one of seven U.S. Senators enshrined in the Senate Reception Room (1957)

Vandenberg, Arthur (born March 1884, died April 1951): Bachelors and Juris Doctorate, University of Michigan (1901); journalist, editor and publisher for Collier's and the Grand Rapids Herald (1901-1928); U.S. Senate (1928-1951) including Majority Leader (1947-1949)

\footnotetext{
${ }^{131}$ Various sources include autobiographies, biographies, and online sources.
} 
Wallace, Henry (born October 1888, died November 1965): Bachelors, Iowa State (1910); editor, then chief editor of Wallaces' Farmer (1910-1929); agricultural businessman (1926-1933); Secretary of Agriculture (Roosevelt, 1933-1940); Vice President (Roosevelt, 1941-1945); Secretary of Commerce (Truman, 1945-1946); Progressive Party nominee for President (1948)

\section{George H.W. Bush Era (1989-1993)}

Baker III, James A. (born April 1930): Bachelors, Princeton University (1952); Juris Doctorate, University of Texas Law School (1957); Marine Corps (1952-1954); law practice (19571969; 1973-1975); White House Chief of Staff (Reagan, 1981-1985; Bush, 1992-1993); Secretary of the Treasury (Reagan, 1985-1988); Secretary of State (Bush, 1989-1993)

Cheney, Richard (born January 1941): attended Yale, Bachelors and Masters Degrees from University of Wyoming, participated in doctoral program at University of Wisconsin; White House Chief of Staff (Ford, 1975-1977); U.S. House of Representatives (Wyoming, 19791989); Secretary of Defense (Bush, 1989-1993); Vice President (Bush, 2001-2009)

Scowcroft, Brent (born March 1925): U.S Military Academy (1944-1947); Lieutenant General, U.S. Air Force (1947-1975); Masters and Doctorate, Columbia University (International Relations, 1953 and 1967); National Security Advisor (Ford, 1975-1977; Bush, 1989-1993)

\section{William (Bill) Jefferson Clinton Era (1993-2001)}

Albright, Madeline (born May 1937, Czechoslovakia): permanent emigration to U.S. in 1948; Bachelors, Wellesley College (Political Science, 1959); journalist, mother, occasional student of Russian and international relations (1959-1966); Masters and Doctorate, Columbia University (International Relations, 1968 and 1975); campaign organizer for Edmund Muskie (1972); Chief Legislative Assistant (1976); Congressional Liaison, NSC (1978-1981); researcher and academic Woodrow Wilson Center for Scholars and Georgetown University (1981-1992); foreign affairs advisor to Geraldine Ferraro (1984) and Michael Dukakis (1988); Ambassador to the United Nations (1993-1997); Secretary of State (1997-2001)

Christopher, Warren (born October 1925, deceased March 2011): University of Southern California (1945); Stanford Law (1946-1949); U.S. Navy Reserve (1943-1946, service in Pacific Theater); law clerk at U.S. Supreme Court (1949-1950); law practice (1950-1967, 1970-1977); Deputy Attorney General (1967-1969); multiple leadership positions with local and state bar associations; President, Board of Trustees, Stanford University and other leadership positions involving education in California; Vice Chair, Governor's Commission on Watts Riots (1965-1966); Director and Vice Chairman, Council on Foreign Relations; Deputy Secretary of State (Carter, 1977-1981); Secretary of State (Clinton, 1993-1997)

Lake, Anthony (born April 1939): Bachelors, Harvard University (1961); Masters, Trinity College, Cambridge (International Economics); Doctorate, Princeton University (International Affairs, 1974); Foreign Service Officer (1962-1970); campaign worker for Edmund Muskie (1972); Director, Policy Planning Staff (Carter, 1977-1981); academic, multiple universities (1981-1992); National Security Advisor (1993-1997) 
Talbott, Strobe (born April 1946): Bachelors, Yale University (1968); Rhodes Scholar, University of Oxford (1968-1972); campaign worker for George McGovern (1972); author on disarmament and diplomatic correspondent for Time Magazine (1973-1991); three time Overseas Press Club Awardee; Ambassador-at-Large and Special Adviser to the Secretary of State (1993); Deputy Secretary of State (Clinton, 1994-2001) 


\section{APPENDIX B: NATIONAL SECURITY DOCTRINES OF U.S. PRESIDENTS ${ }^{132}$}

Monroe Doctrine (1823): established separate spheres of influence between Europe and the Americas, each eschewing intervention and colonization in the other [Monroe, James. “Seventh Annual Message,” Address to Congress, December 2, 1823]

Roosevelt Doctrine (1904): a corollary to the Monroe Doctrine; United States would intervene as a last resort to ensure other nations in the Western Hemisphere fulfilled their obligations to international creditors, and did not violate the rights of the United States or invite "foreign aggression to the detriment of the entire body of American nations" [Roosevelt, Theodore. "Fourth Annual Message," Address to Congress, December 6, 1904]

Polk Doctrine (1845): statement on American unilateralism, exceptionalism, and expansion, collectively known as Manifest Destiny [Polk, James. "First Annual Message," Address to Congress, December 2, 1845]

Wilson Doctrine (1918): expresses universal nature of democracy and ultimate victory of democracy around the world; advocated peace of equals, peace without revenge, selfdetermination for all peoples, establishment of League of Nations (i.e., strengthening of international law) [several sources, but culminates in Wilson, Woodrow. "Fourteen Points Speech," Address to Congress, January 8, 1918]

\footnotetext{
${ }^{132}$ Lamont Colucci, The National Security Doctrines of the American Presidency: How They Shape Our Present and Future [2 Volumes] (Santa Barbara, CA: Praeger, 2012). Speeches at Presidential Speech Archive, The Miller Center, University of Virginia, http://millercenter.org/president/speeches; narratives, documents, and speeches found on The Office of the Historian, United States Department of State, http://history.state.gov/milestones. Colucci catalogues sixteen presidential doctrines, but believes only six succeeded (Washington, Lincoln, T. Roosevelt, Truman, Reagan, Bush), four were constructive (Monroe, Polk, Roosevelt, Eisenhower), and six failed (Wilson, Hoover, Nixon, Carter, Clinton, Obama). Colucci, 500-501. While insightful, there seems to be an ideological bias in his work.
} 
Truman Doctrine (1947): the United States would provide financial aid, material, and military force to "support free peoples who are resisting subjugation by armed minorities or by outside pressures” [Truman, Harry S. “Truman Doctrine,” Address to Congress, March 12, 1947]

Eisenhower Doctrine (1957): any country could request American economic and/or military aid if threatened by armed aggression from another state [Eisenhower, Dwight D. “Eisenhower Doctrine," Address to Congress, January 5, 1957]

Johnson Doctrine (1965): the United States “will not permit the establishment of another Communist government in the Western Hemisphere"; revolutions are internal matters that become hemispheric matters "when the object [of that revolution] is the establishment of a communistic dictatorship." [Johnson, Lyndon. "Report on the Situation in the Dominican Republic," Address to the Nation, May 2, 1965]

Nixon Doctrine (1969): United States expected allies to assume primary responsibility for its defense; United States would honor its treaty obligations, provide a nuclear shield to defend vital interest, and shall provide aid to those who request it but expects that nation to be the primary source of manpower in its defense [Nixon, Richard. "War in Vietnam," Address to the Nation, November 23, 1969]

Carter Doctrine (1980): the United States would use military force to defend its interests in the Persian Gulf; U.S. would not allow an outside party to gain control of the Gulf [Carter, James E. "State of the Union," Address to Congress, January 23, 1980]

Reagan Doctrine: the United States would provide overt and covert aid to anti-communist guerrillas and resistance movements in an effort to "roll back" Soviet-backed communist governments in Africa, Asia, and Latin America [various sources, see Colucci]

Clinton Doctrine (1999): the United States would act "where our values and our interests are at stake, and where we can make a difference, we must be prepared to do so." Added Clinton, "genocide is in and of itself a national interest where we should act ... if somebody comes after 
innocent civilians and tries to kill them en masse because of their race, their ethnic background or their religion, and it's within our power to stop it, we will stop it." [Clinton, William J. "Remarks on Foreign Policy," Speech in San Francisco, California, February 26, 1999]

Bush Doctrine (2002): the United States would act against those providing aid to terrorists, it would act preemptively against potential threats, it sought the spread of democracy to defeat extremism, and it would act unilaterally [various, including: Bush, George. The National Security Strategy of the United States. Washington, DC: The White House, 2002] 


\section{APPENDIX C: AMERICAN NATIONAL SECURITY POLICY TRADITIONS}

Promised Land, Crusader State, by Walter A. McDougall

- Liberty, or Exceptionalism

- Unilateralism, or Isolationism

- The American System, or Monroe Doctrine

- Expansionism, or Manifest Destiny
- Progressive Imperialism

- Wilsonianism, or Liberal Internationalism (so called)

- Containment

- Global Meliorism

The National Security Doctrines of the American Presidency: How They Shape Our Present and Future. Volumes 1 and 2, by Lamont Colucci

- Exceptionalism

- Manifest Destiny and Expansionism

- Empire of liberty and promotion of liberal democracy

- Free trade and commerce

- Unilateralism

Surprise, Security and the American Experience, by John Lewis Gaddis

- Preemption: react swiftly and forcibly to attacks, enlarge sphere of responsibility to shape

- Unilateralism: reject alliances requiring response to unforeseeable developments involving other nations

- Hegemony: predominate in the Western Hemisphere
- Internationalism

- American way of way

- Geography, geostrategy, and geopolitics

- Primacy 


\section{APPENDIX D: UNCITED REFERENCES FOR ADDITIONAL RESEARCH ${ }^{133}$}

Best, Jr., Richard A. National Security Council: An Organizational Assessment. New York: Novinka Books, 2001.

Bohlen, Charles E. The Transformation of American Foreign Policy. New York: Norton, 1969. . Wtiness to History: 1929-1969. New York: Norton, 1973.

- Summary of the activities of an American ambassador assigned to key countries and recollections of the evolution of U.S. policy toward the Soviet Union from the closing years of World War II through the depths of the Cold War

Bowie, Robert R., and Richard H. Immerman. Waging Peace: How Eisenhower Shaped an Enduring Cold War Strategy. New York: Oxford University Press, USA, 2000.

Gurman, Hannah. The Dissent Papers : The Voices of Diplomats in the Cold War and Beyond. New York: Columbia University Press, 2012.

- Beginning with the Cold War and concluding with the 2003 invasion of Iraq, Hannah Gurman explores the overlooked opposition of U.S. diplomats to American national security policies in the latter half of the twentieth century.

Lebow, Richard N. and Janice G. Stein. We All Lost the Cold War. Princeton, N.J.: Princeton University Press, 1994.

- Hypothesizes that deterrence prolonged rather than ended the conflict between the United States and the Soviet Union.

Leffler, Melvyn. For the Soul of Mankind. New York: Hill \& Wang, 2007.

- Study of how the Cold War began and ended.

McCormick, James M. (ed.) The Domestic Sources of American Foreign Policy: Insights and Evidence. Lanham, MD: Rowman \& Littlefield, 2012

- Introduction to the broad array of domestic factors influencing U.S. policymakers.

Mueller, John. Retreat from Doomsday: the Obsolescence of Major War. New York: Basic Books, 1989.

- Offers a detailed history of public policies and attitudes to war in modern times. The author sets out to show that major war as a policy option among developed nations has gradually passed out of favor. He also contends that nuclear weapons have not had an

\footnotetext{
${ }^{133}$ Other useful references not specifically cited in this text. Summaries from www.amazon.com.
} 
important impact on this trend, neither making a crucial contribution to nor severely threatening post-war stability. Similar to End of History?

Nottberg, Tyler. "Once and Future Policy Planning: Solarium for Today." The Eisenhower Institute at Gettysburg College. 2003.

http://www.eisenhowerinstitute.org/about/living_history/solarium_for_today.dot (accessed March 3, 2014).

Priest, Dana. The Mission: Waging War and Keeping Peace with America's Military. New York: W. W. Norton \& Company, 2003.

- Account of America's growing dependence on the military to manage world affairs. It describes a clash of culture and purpose through the eyes of soldiers and officers themselves. In the aftermath of September 11, this trend has only accelerated, as the country turns to its warriors to solve the complex international challenges ahead.

Roberts, Brad (ed). U.S. Foreign Policy After the Cold War. Cambridge, MA: MIT Press, 1992.

Tocqueville, Alexis de. Democracy in America. New York: Penguin Putnam, 2004.

- Published in 1835, French political scientist-philosopher's view on democracy in the United States, with emphasis on its strengths, weaknesses, opportunities and challenges

Toffler, Alvin. Future Shock. New York: Random House, 1970.

- Examines the effects of rapid industrial and technological changes upon the individual, the family, and society. . The Third Wave. New York: William Morrow, 1980.

- Sequel to Future Shock; describes transition in developed countries from Industrial Age society, which he calls the "Second Wave", to Information Age "Third Wave" society. 


\section{BIBLIOGRAPHY}

Abelson, Donald E. A Capitol Idea: Think Tanks and US Foreign Policy. Montreal: McGillQueen's University Press, 2006.

Acheson, Dean. "The Requirements of Reconstruction." Vital Speeches of the Day 13, no. 16 (May 1947): 485-487.

. Present at the Creation: My Years in the State Department. New York: W.W. Norton \& Co., 1969.

Almond, Gabriel A. The American People and Foreign Policy. New York: Frederick A Praeger, 1960.

Bain, Richard C. Convention Decisions and Voting Records, 2d ed. Washington, DC: Brookings Institution, 1974.

Baker III, James A., and Thomas M. DeFrank. The Politics of Diplomacy: Revolution, War and Peace. New York: Putnam's Sons, 1995.

Beschloss, Michael R., and Strobe Talbott. At the Highest Levels: The Inside Story of the End of the Cold War. New York: Little Brown and Co., 1993.

Best, Jr., Richard A. National Security Council: An Organizational Assessment. New York: Novinka Books, 2001.

Blum, John Morton, editor. The Price of Vision, the Diary of Henry a Wallace 1942-1946. Boston: Houghton Mifflin, 1974.

Brinkley, Douglas. "Democratic Enlargement: The Clinton Doctrine." Foreign Policy (Spring 1997): 110-127.

Brown, Seyom. The Faces of Power: U.S. Foreign Policy from Truman to Clinton. New York: Columbia University Press, 1994.

Bryan, Ferald J. "George C. Marshall at Harvard: A Study of the Origins and Construction of the 'Marshall Plan' Speech.” Presidential Studies Quarterly (Summer 1991): 489-502. http://www.jstor.org/discover/10.2307/27550768?uid=3739744\&uid=2\&uid=4\&uid=373 9256\&sid=21103694767723 (accessed March 9, 2014).

Bush, George H.W. "Commencement Address.” Texas A\&M University, College Station, TX, March 12, 1989. http://millercenter.org/president/speeches/detail/3421 (accessed March 9, 2014).

“The President's News Conference.” Public Papers - 1989 - December. http://bushlibrary.tamu.edu/research/public_papers.php?id=1298\&year=1989\&month=12 (accessed March 9, 2014). 
Bush, George H.W., and Brent Scowcroft. A World Transformed. New York: Alfred A. Knopf, 1998.

Cameron, Fraser. U.S. Foreign Policy After the Cold War: Global Hegemon or Reluctant Sheriff. 2d. New York: Routledge, 2005.

Cardwell, Curt. NSC 68 and the Political Economy of the Early Cold War. New York: Cambridge University Press, 2011.

Christopher, Warren. “International Peace.” Vital Speeches of the Day 59, no. 13 (April 15, 1993): 386-390.

http://web.b.ebscohost.com.lumen.cgsccarl.com/ehost/detail?vid=3\&sid=c1d2ba1d-337c4b2d-8ebd-518dba39d3cf\%40sessionmgr 198\&hid=108\&bdata= JnNpdGU9ZWhvc3Qtb Gl2ZQ\%3d\%3d\#db=khh\&AN=9304270600 (accessed March 9, 2014).

. In the Stream of History: Shaping Foreign Policy for a New Era. Stanford, CA: Stanford University Press, 1998.

Churchill, Winston. "The Sinews of Peace.” Address, Westminster College, Fulton, MO, March 5, 1946. http://www.nato.int/docu/speech/1946/s460305a_e.htm (accessed September 3, 2013).

Clinton, William J. "Remarks on Foreign Policy." Speech in San Francisco, February 26, 1999, https://www.mtholyoke.edu/acad/intrel/clintfps.htm (accessed March 9, 2014) My Life. New York: Random House, 2004.

Colucci, Lamont. The National Security Doctrines of the American Presidency: How They Shape Our Present and Future [2 Volumes]. Santa Barbara, CA: Praeger, 2012.

Dabelko, Geoffrey D. "The Environmental Factor." The Wilson Quarterly 23, no. 4 (Autumn 1999): 14-19.

Destler, I. M., Leslie H Gelb, and Anthony Lake. Our Own Worst Enemy. New York: Simon \& Schuster, 1984.

Drezner, Daniel W., ed. Avoiding Trivia: the Role of Strategic Planning in American Foreign Policy. Washington, DC: Brookings Institution Press, 2009.

Eagleburger, Lawrence, Judy Woodruff, Claus Kleber, and Steven Livingston, interview by Stephen Hess, and Marvin Kalb. "The CNN Effect: How 24-Hours News Coverage Affects Government Decisions and Public Opinion." A Brookings/Harvard Forum: Press Coverage and the War on Terrorism. (January 16, 2002).

Flournoy, Michele, and Shawn Brimley. "Strategic Planning for National Security: A New Project Solarium." Joint Forces Quarterly, no. 41 (2d Quarter 2006): 80-86.

Fukuyama, Francis. "The End of History." The National Interest 16 (Summer 1989): 3-18. 
Fulbright, J. William. Arrogance of Power. New York: Random House, 1966.

Gaddis, John L. Surprise, Security and the American Experience. Cambridge, MA: Harvard University Press, 2004.

Gates, Robert M. From the Shadows. New York: Simon \& Schuster, 1996.

. "Importance of Soft Power." Speech, Kansas State University, Manhattan, KS, November 26, 2007. http://www.defense.gov/speeches/speech.aspx? speechid=1199 (accessed March 4, 2014).

Gilbert, Martin. Churchill: A Life. New York: Henry Holt \& Co., 1992.

Goldgeier, James M., and Derek H. Chollet. "The Truman Standard." The American Interest 1 (Summer 2006): 107-11. http://www.cfr.org/history-and-theory-of-internationalrelations/truman-standard/p10813 (accessed March 16, 2014).

Graebner, Norman A., Richard D. Burns, and Joseph M. Siracusa. American and the Cold War, 1941-1991. Praeger Security International, 2010.

http://psi.praeger.com/doc.aspx?d=/books/gpg/A2979C/A2979C-1379.xml (accessed December 30, 2013).

Grose, Peter. Continuing the Inquiry: The Council on Foreign Relations from 1921 to 1996. New York: Council on Foreign Relations, 1996.

Haass, Richard. "Fatal Distraction: Bill Clinton's Foreign Policy.” Foreign Policy no. 108 (Fall 1997). http://web.a.ebscohost.com.lumen.cgsccarl.com/ehost/detail?sid=530a95d8-a8f04594-bb92-5cc4f4273d51\%40sessionmgr4001\&vid=5\&hid=4212\&bdata=JnNpdGU 9ZWhvc3QtbGl2ZQ\%3d\%3d\#db=f5h\&AN=9710166012 (accessed March 9, 2014).

Harriman, W. Averell. America and Russia in a Changing World: A Half Century of Personal Observation. New York: Doubleday \& Co., 1971.

Herspring, Dale R. The Pentagon and the Presidency: Civil Military Relations from FDR to George W. Bush. Lawrence: University Press of Kansas, 2005.

Hitchens, Harold L. "Influences on the Congressional Decision to Pass the Marshall Plan." The Western Political Quarterly 21, no. 1 (1968): 51-68.

Homer-Dixon, Thomas F. "On the Threshold: Environmental Changes as Causes of Acute Conflict." International Security 16, no. 2 (Fall 1991): 76-116.

Huntington, Samuel. "Democracy's Third Wave." Journal of Democracy 2, no. 2 (Spring 1991): 12-34. . "Clash of Civilizations." Foreign Affairs 72, no. 3 (Summer 1993): 22-49.

Hyland, William G. Clinton's World: Remaking American Foreign Policy. Westport, CT: Praeger Publishers, 1999. 
Ikenberry, G. John. After Victory: Institutions, Strategic Restraint, and the Rebuilding of Order After Major Wars. Princeton, NJ: Princeton University Press, 2001.

Isaacs, Jeremy. Cold War: The Complete Series. Directed by Vivian Schiller, Martin Smith, Taylor Downing, \& Richard Melman. Time Warner Home Video, 1998.

Isaacs, Walter, and Evan Thomas. The Wise Men: Six Friends and the World They Made. New York: Simon \& Schuster, 1986.

Jackson, Scott. "Prologue to the Marshall Plan: The Origins of the American Commitment for a European Recovery Plan." The Journal of American History 65, no. 4 (March 1979): 1043-1068.

Jones, Joseph M. The Fifteen Weeks. New York: Viking Press, 1955.

Kane, Tim. "Global U.S. Troop Deployment, 1950-2005."

http://www.heritage.org/research/reports/2006/05/global-us-troop-deployment-1950-2005 (accessed December 22, 2013).

Kaplan, Robert D. "The Coming Anarchy." The Atlantic Monthly 273, no. 2 (1994): 44-76. The Coming Anarchy. New York: Random House, 2000.

Kaufman, Michael T. "The Dangers of Letting a President Read." The New York Times. May 22, 1999. http://www.nytimes.com/1999/05/22/books/the-dangers-of-letting-a-presidentread.html (accessed February 3, 2014).

Kennan, George. "Telegram to the Secretary of State." In Foreign Relations of the United States, 1946. Eastern Europe, the Soviet Union, by United States Department of State, 696-709. Washington, DC: Government Printing Office, 1946.

_. "Sources of Soviet Conduct." Foreign Affairs 65, no. 4 (Spring 1987): 852-868. . Memoirs: 1925-1950. Boston: Little \& Brown, 1967.

Kennan, George F. and John Lukacs. George F. Kennan and the Origins of Containment (19441946): The Kennan-Lukacs Correspondence. Columbia, MO: University of Missouri Press, 1997.

Kissinger, Henry. Does America Need A Foreign Policy? New York: Simon \& Schuster, 2001.

Krasner, Stephen D. "An Orienting Principle for Foreign Policy." Policy Review, OctoberNovember 2010: 3-12.

Lake, Anthony. "From Containment to Enlargement." Vital Speeches of the Day 60, no. 1 (October 1, 1993): 13-19. http://web.b.ebscohost.com.lumen.cgsccarl.com/ehost/detail?vid=3\&sid=c1d2ba1d-337c4b2d-8ebd-518dba39d3cf\%40sessionmgr198\&hid=108\&bdata= JnNpdGU9ZWhvc3 QtbGl2ZQ\%3d\%3d\#db=khh\&AN=9402012365 (accessed March 9, 2014). 
Leffler, Melvyn. A Preponderance of Power: National Security, the Truman Administration, and the Cold War. Stanford, CA: Stanford University Press, 1992.

Lippmann, Walter “One World of Diversity." Vital Speeches of the Day 13, no. 5 (December 15, 1946): 138-40. http://web.b.ebscohost.com.lumen.cgsccarl.com/ehost/detail?vid=3\&sid=c1d2ba1d-337c4b2d-8ebd-518dba39d3cf\%40sessionmgr198\&hid=108\&bdata=JnNpdGU9ZWhvc3Qtb Gl2ZQ\%3d\%3d\#db =khh\&AN=9751344 (accessed March 9, 2014).

. The Cold War: A Study in U.S. Foreign Policy. New York: Harper Brothers Publishers, 1947.

Lord, Carnes. The Presidency and the Management of National Security. New York: The Free Press, 1988.

Lovell, John P. The Challenge of American Foreign Policy: Purpose and Adaption. New York: Macmillan Publishing Company, 1985.

Lukacs, John. 1945: Year Zero. Garden City, NY: Doubleday and Co., 1978.

Marshall, George C. “Alumni Day Message.” Speech, Princeton University, Princeton, NJ, February 22, 1947.

http://blogs.princeton.edu/paw/files/import/i-94a2781582f2ac16b06e4b70ee1363f4george_marshall_AlumniDay.pdf (accessed March 9, 2014).

. “European Unity.” Vital Speeches of the Day 13, no. 18 (July 1, 1947): 553-554. http://web.b.ebscohost.com.lumen.cgsccarl.com/ehost/pdfviewer/pdfviewer?vid=3\&sid= c1d2ba1d-337c-4b2d-8ebd-518dba39d3cf\%40sessionmgr198\&hid=108 (accessed March 9, 2014).

McDougall, Walter A. Promised Land, Crusader State: The American Encounter with the World Since 1776. New York: Houghton Mifflin Co., 1997.

Mearsheimer, John J. "Back to the Future: Instability in Europe After the Cold War." International Security 15, no. 1 (Summer 1990): 5-56.

. "Why We Will Soon Miss the Cold War." The Atlantic Monthly 266, no. 2 (August 1990): 35-50.

. "Disorder Restored." In Rethinking America's Security, edited by Graham Allison, \& Gregory F. Treverton, 213-237. New York: W.W. Norton \& Co., 1992.

_. The Tragedy of Great Power Politics. New York: W.W. Norton \& Co., 2001.

Miscamble, Wilson D. "George Kennan: A Life in the Foreign Service." Foreign Service Journal 81, no. 2 (May 2004): 22-34.

. From Roosevelt to Truman: Potsdam, Hiroshima, and the Cold War. New York:

Cambridge University Press, 2007. 
. "Harry S. Truman, the Bomb, and the Transformation of U.S. Foreign Policy." Lecture, Florida Atlantic University, Boca Raton, FL, 2008.

http://www.fau.edu/osullivan/images/Wilson_D__Miscamble_pub.pdf (accessed September 27, 2013).

Mueller, John E. "Public Expectations of War During the Cold War." American Journal of Political Science 23, no. 2 (May 1979): 301-329.

National Security Act of 1947, Public Law 80, § 253, U.S. Statutes at Large 61 (1947): 495-510, codified at U.S. Code 50 (1947), $§ 401$

http://www.intelligence.senate.gov/nsact1947.pdf (accessed March 14, 2014)

Nelson, Anna Kasten. "President Truman and the Evolution of the National Security Council." Journal of American History 72, no. 2 (1985): 360-378.

North Atlantic Council. "The Alliance's New Strategic Concept.” North Atlantic Treaty Organization Texts. http://www.nato.int/cps/en/natolive/official_texts_23847.htm (accessed February 11, 2014).

Office of Management and Budget. Historical Tables: Budget of the United States Government, Fiscal Year 2009. Washington, DC: Government Printing Office, 2008.

Office of the Historian, United States Congress. "Vandenberg, Arthur Hendrick (1884-1951)."

Biographical Directory of the United States Congress. http://bioguide.congress.gov/ scripts/biodisplay.pl?index=V000025 (accessed November 13, 2013).

Paterson, Thomas G. "Superpower Decline and Hegemonic Survival." In Major Problems in American Foreign Relations, edited by Thomas G. Paterson, \& Dennis Merrill, 727-738. Lexington, MA: D.C. Heath and Company, 1995.

Prados, John. Keeper of the Keys: A History of the National Security Council from Truman to Bush. New York: William Morrow \& Co., 1991.

Renaissance Institute. "The Weekends.” Renaissance Weekend, The Renaissance Institute. http://www.renaissanceweekend.org/aboutus/aboutus.htm (accessed February 4, 2014).

Rodman, Peter W. Presidential Command: Power, Leadership and the Making of Foreign Policy from Richard Nixon to George W. Bush. New York: Alfred A. Knopf, 2009.

Root, Elihu. "A Requisite for the Success of Popular Diplomacy." Foreign Affairs 1, no. 1 (1922): 1.

Rothkopf, David. Running the World: The Inside Story of the National Security Council and the Architects of American Power. New York: Public Affairs, 2005.

Schnabel, James. History of the Joint Staff: The Joint Chiefs of Staff and National Policy 19451947. Vol. 1. Washington, DC: Office of the Joint Historian, 1996. 
Scott, James M. "Interbranch Rivalry and the Reagan Doctrine in Nicaragua." Political Science Quarterly 112, no. 2 (Summer 1997): 237-260.

Shoup, Laurence H., and William Minter. Imperial Brain Trust: the Council on Foreign Relations and United States Foreign Policy. Lincoln, NE: Authors Choice Press, 2004.

Steel, Ronald. Walter Lippmann and the American Century. Boston: Atlantic Monthly Press, 1980.

Stoler, Mark A. Allies and Adversaries: The Joint Chiefs of Staff, the Grand Alliance, and US Strategy in World War II . Chapel Hill, NC: The University of North Carolina Press, 2000.

Taft, Robert A. “A Post-War Peace Organization of Nations.” Vital Speeches of the Day 10, no. 16 (June 1, 1944): 492-95.

http://web.b.ebscohost.com.lumen.cgsccarl.com/ehost/detail?vid=3\&sid=c1d2ba1d-337c4b2d-8ebd-518dba39d3cf\%40sessionmgr198\&hid=108\&bdata=JnNpdGU9ZWhvc3 QtbGl2Z Q\%3d\%3d\#db=khh\&AN=9762957 (accessed March 9, 2014).

Talbott, Strobe. "Democracy and the National Interest." Foreign Affairs 75, no. 6 (1996): 47-63. . The Russia Hand. New York: Random House, 2002.

Time Editorial Board. “The Eightieth Congress.” Time (January 6, 1947): 19. http://web.a.ebscohost.com.lumen.cgsccarl.com/ehost/results?sid=b1a5766c-530f-436e8ca6-00259c7f7efd\%40sessionmgr4005\&vid=3\&hid $=4212 \&$ bquery $=\% 22 \mathrm{The}+80$ th + Congress\%22\&bdata=JmRiPWE5aCZkYj1idGgmZGI9bXRoJmRiPTMxaCZkYj1oaWE mZGI9cG9oJmRiPWY1aCZkYj1id2gmZGI9a2hoJ (accessed March 9, 2014).

Treveton, Gregory F., and Barbara A. Bicksler. "Conclusion: Getting from Here to Where?" In Rethinking America's Security: Beyond Cold War to the New World Order, by Allison Graham, \& Gregory F. Treveton, 407-433. New York: W.W. Norton \& Company, 1992.

Truman, Harry S. “Aid to Greece and Turkey.” Vital Speeches of the Day 13, no. 11 (1947): 32224. http://vsotd.com/speech-archive (accessed March 9, 2014). . Memoirs: Year of Decisions. Garden City, N.Y.: Doubleday \& Company, 1955.

Truman, Margaret. Harry S. Truman. New York: Wiliam Morrow \& Co., 1973.

United States Department of Commerce. Statistical Abstract of the United States: 2012. Washington, DC: Government Printing Office, 2012. . Statistical Abstract of the United States: 1954. Washington, DC: Government Printing Office, 1954.

United States Department of State. Foreign Relations of the United States, 1944, Europe. Vol. IV, 902-14. Washington, DC: U.S. Government Printing Office, 1944. 
. Foreign Relations of the United States, 1947: The British Commonwealth; Europe. Vol. III, 204-232. Washington, DC: U.S. Government Printing Office, 1947.

. Foreign Relations of the United States, 1948: General, The United Nations (in Two Parts). Vols. I, Part 2. Washington, DC: U.S. Government Printing Office, 1948.

United States Office of the Special Counsel, White House. American Relations with the Soviet Union, by Clark Clifford. Washington, DC, 1946.

United States Senate Historian. "Arthur Vandenberg: A Featured Biography.” U.S. Senate Art \& History. http://www.senate.gov/artandhistory/history/common/generic/Featured_Bio_ Vandenberg.htm (accessed October 19, 2013).

. "Merchants of Death." U.S. Senate Art \& History.

http://www.senate.gov/artandhistory/history/minute/merchants_of_death.htm (accessed October 19, 2013).

Vandenberg, Arthur S. "Peace or War for America." Vital Speeches of the Day 5, no. 12 (April 1, 1939): 354-57.

http://web.b.ebscohost.com.lumen.cgsccarl.com/ehost/detail?vid=5\&sid=c1d2ba1d-337c4b2d-8ebd-518dba39d3cf\%40sessionmgr198\&hid=108\&bdata=JnNpdGU9ZWhvc3 QtbGl2ZQ\%3d\%3d\#db= khh\&AN=9735993 (accessed October 19, 2013).

. "The Need for Honest Candor." Vital Speeches of the Day 11, no. 8 (February 1, 1945): 226-30.

http://web.b.ebscohost.com.lumen.cgsccarl.com/ehost/detail?vid=5\&sid=c1d2ba1d-337c4b2d-8ebd-518dba39d3cf\%40sessionmgr 198\&hid=108\&bdata= JnNpdGU9ZWhvc3Q tbGl2ZQ\%3 d\%3d\#db=khh\&AN=9735993 (accessed October 19, 2013).

. "Bipartisan Foreign Policy." Vital Speeches of the Day 15, no. 1 (November 1, 1948): $11-15$. http://web.b.ebscohost.com.lumen.cgsccarl.com/ehost/detail?vid=3\&sid=c1d2ba1d-337c4b2d-8ebd-518dba39d3cf\%40sessionmgr198\&hid=108\&bdata=JnNpdGU9ZWhvc3Qtb Gl2ZQ\%3d\%3d\#db=khh\&AN=9758859 (accessed March 9, 2014).

. "Soviet Pressure, A World Peril." Vital Speeches of the Day 13, no. 13 (April 15, 1947): 391-396.

http://web.b.ebscohost.com.lumen.cgsccarl.com/ehost/detail?vid=3\&sid=c1d2ba1d-337c4b2d-8ebd-518dba39d3cf\%40sessionmgr198\&hid=108\&bdata=JnNpdGU9ZWhvc3Qtb G 12ZQ\%3d\%3d\#db=khh\&AN=9753160 (accessed March 9, 2014).

Wala, Michael. The Council on Foreign Relations and American Foreign Policy in the Early Cold War. Providence: Berghahn Books, 1994.

Wallace, Henry. “The Way to Peace.” Vital Speeches of the Day 12, no. 24 (October 1, 1946): 738-41.

http://web.b.ebscohost.com.lumen.cgsccarl.com/ehost/detail?vid=3\&sid=c1d2ba1d-337c4b2d-8ebd-518dba39d3cf\%40sessionmgr198\&hid=108\&bdata=JnNpdGU9ZWhvc3 QtbGl2ZQ\%3d\%3d\#db=khh\&AN=9744687 (accessed March 9, 2014). 
. "I Shall Run in 1948." Vital Speeches of the Day 14, no. 6 (January 1, 1948): 172-74. http://web.b.ebscohost.com.lumen.cgsccarl.com/ehost/detail?vid=3\&sid=c1d2ba1d-337c4b2d-8ebd-518dba39d3cf\%40sessionmgr198\&hid=108\&bdata=JnNpdGU9ZWhvc3Q tbGl2ZQ\%3d\%3d\#db=khh\&AN=9739824 (accessed March 9, 2014).

Weber, Ralph E., ed. Talking with Harry: Candid Conversations with President Harry S. Truman. Wilmington, Delaware: Scholarly Resources, 2001.

Western, Jon. "Sources of Humanitarian Intervention: Beliefs, Information, and Advocacy in the U.S." International Security 26, no. 4 (Spring 2002): 112-142.

The White House. The National Security Strategy of the United States, by Ronald Reagan. Washington, DC, 1988. . National Security Review 12, by George H.W. Bush. Washington, DC, 1989.

. The National Security Strategy of the United States, by George H.W. Bush. Washington, DC, 1990.

. The National Security Strategy of the United States, by George H.W. Bush. Washington, DC, 1991.

. The National Security Strategy of the United States, by George H.W. Bush. Washington, DC, 1993.

. A National Security Strategy for a New Century, by William J. Clinton. Washington, DC, 1999.

Wilcox, Francis O., interview by Donald Ritchie. Senate Oral History Program (February-March 1984). http://www.senate.gov/artandhistory/history/oral_history/Francis_O_Wilcox.htm (accessed March 9, 2014).

Will, George F. "Europe's Second Reformation." Newsweek 114, no. 21 (November 1989): 90.

Winik, Jay. "Quest for Bipartisanship: A New Beginning for a New World Order." In U.S. Foreign Policy After the Cold War, by Brad Roberts (ed.), 311-326. Cambridge, MA: MIT Press, 1992.

Wunderlin, Clarence E. Robert A. Taft: Ideas, Traditions, and Party in U.S. Foreign Policy. Lanham, MD: Rowman \& Littlefield Publishers, 2005.

Zegart, Amy. Flawed by Design: the Evolution of the CIA, JCS, and NSC. Stanford: Stanford University Press, 2000 